\title{
The Assessment of Instruments for Detecting Surface Water Spills and a Three-Dimensional Model of the Elk River Spill
}

Aubrey E. Harris

Follow this and additional works at: https://researchrepository.wvu.edu/etd

\section{Recommended Citation}

Harris, Aubrey E., "The Assessment of Instruments for Detecting Surface Water Spills and a ThreeDimensional Model of the Elk River Spill" (2015). Graduate Theses, Dissertations, and Problem Reports. 5769.

https://researchrepository.wvu.edu/etd/5769

This Thesis is protected by copyright and/or related rights. It has been brought to you by the The Research Repository @ WVU with permission from the rights-holder(s). You are free to use this Thesis in any way that is permitted by the copyright and related rights legislation that applies to your use. For other uses you must obtain permission from the rights-holder(s) directly, unless additional rights are indicated by a Creative Commons license in the record and/ or on the work itself. This Thesis has been accepted for inclusion in WVU Graduate Theses, Dissertations, and Problem Reports collection by an authorized administrator of The Research Repository @ WVU. For more information, please contact researchrepository@mail.wvu.edu. 


\title{
The Assessment of Instruments for Detecting Surface Water Spills and a Three-Dimensional Model of the Elk River Spill
}

\author{
Aubrey E. Harris \\ Thesis submitted \\ to the Benjamin M. Statler College of Engineering and Mineral Resources \\ at West Virginia University \\ in partial fulfillment of the requirements for the degree of \\ Master of Science in \\ Civil and Environmental Engineering
}

Leslie Hopkinson, Ph.D., Chair

Lian-Shin Lin, Ph.D.

Nicolas Zegre, Ph.D.

Department of Civil and Environmental Engineering

Morgantown, West Virginia

2015

Keywords: water quality instrumentation, numerical simulation, surface water systems, modeling, early warning systems, fate and transport of pollutants

Copyright 2015 Aubrey E. Harris 


\title{
ABSTRACT \\ The Assessment of Instruments for Detecting Surface Water Spills and a Three-Dimensional Model of the Elk River Spill
}

\begin{abstract}
Aubrey E. Harris
Source water protection has been an increasing area of concern due to the risks associated with chemical storage and oil and gas operations. To better identify and mitigate risk, models and tools are needed to evaluate the dispersion of pollutants in possible spill scenarios. This information may be used to determine the placement of in-stream water quality monitoring instruments and to develop early-warning systems and emergency plans.

In this work, two approaches of applying chemical dispersion models are described: one to determine the necessary concentration to generate a signal from in-stream measurements; and second to demonstrate, in a numerical three-dimensional model, how the chemical properties and river mixing during a spill affect the distribution of a chemical as it is transported downstream.

In the instrument assessment study, spills associated with oil and gas operations were identified within the Susquehanna River Basin Commission's Remote Water Quality Monitoring Network. The contaminants and expected peak concentration at monitoring stations were used in laboratory experiments to determine if a signal from low concentrations of spill contaminants can be identified by current water quality monitoring techniques and locations. The results were compared to historical data and natural changes in water quality parameters, and it was found that the contaminants tested do affect commonly measured water quality parameters. The volume of certain contaminants is sufficient to affect the water quality of certain drainage areas.

The three-dimensional model developed in this work was based on the Elk River Spill that occurred in Charleston, WV on January 9, 2014. Cross-section measurements of the Elk River were used to create the model geometry. Different chemical and hydrologic scenarios were simulated. It was found that physical parameters such as dispersion and loading rate affect plume size and peak concentration. After building the model, the numerical simulation method was versatile in simulating different chemical properties, loading rates, and hydrologic dispersion rates.

This work is an effort to demonstrate that hydrologic and water quality models may be applied to improve the placement of water quality monitoring devices. This information may increase the capacity of early-warning systems to mitigate surface water spills.
\end{abstract}




\section{ACKNOWLEDGEMENTS}

The instrument assessments were conducted under Task 14 of the Energy Policy Act of 2005. I would like to thank National Energy Technology Laboratory for providing funding and laboratory resources for conducting the research for the instrument assessments. I would like to thank Dr. Leslie Hopkinson for her extraordinary support in this thesis process. Thank you to Dan Soeder for developing the water resources research program at the National Energy Technology Laboratory.

I would like to thank Dr. Lance Lin and Dr. Jennifer Weidhaas for their swift response after the Elk River Spill, without their participation in the National Science Foundation's RAPID response program, the model of the Elk River Spill would not have been possible. I would like to thank Dr. Lance Lin for extending the opportunity to work on this three-dimensional model to see it reach completion. I would like to acknowledge Dr. Nicolas Zegre and Dr. Michael Strager for their support in the watershed hydrology component of this project. Thank you to Dr. Paul Ziemkiewicz for his contributions in water research in West Virginia.

I would like to thank the Susquehanna River Basin Commission for developing a rigorous water quality monitoring program, and for sharing their data with the general public. Without access to these data, the instrument assessment would not have been possible. I would like to thank Friends of the Cheat and the AmeriCorps Volunteer in Service to America for extending the opportunity for me to work alongside their remote water quality monitoring network and their team of volunteers; the contribution of these organizations to the community is invaluable.

Finally I would like to thank my parents for their support throughout my academic career, especially during the composition of this thesis. Without their encouragement, I would not have found my passion in water resource engineering. 


\section{Table of Contents}

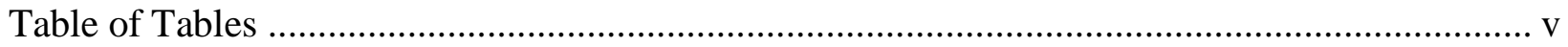

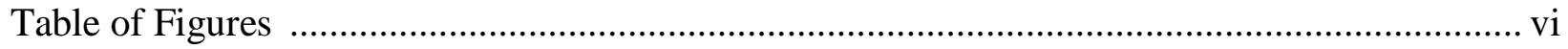

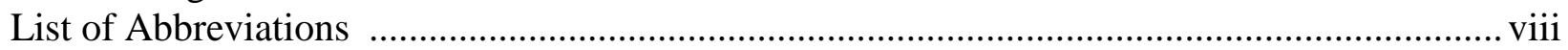

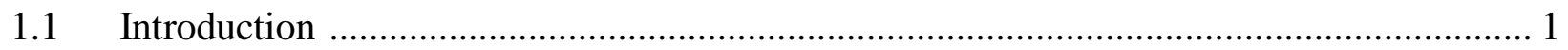

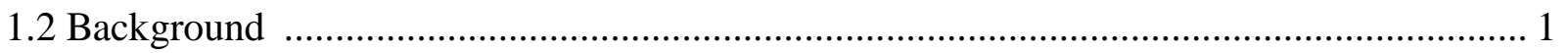

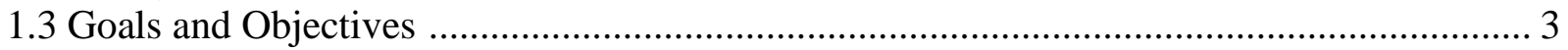

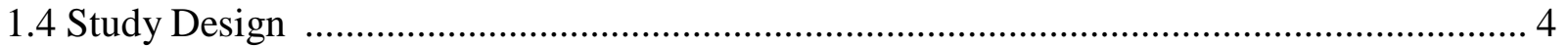

2.1 Assessing the use of instruments for detecting surface water spills .................................. 5

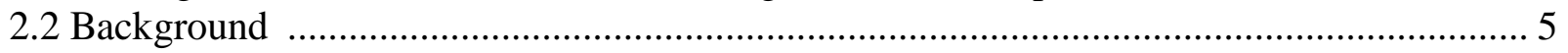

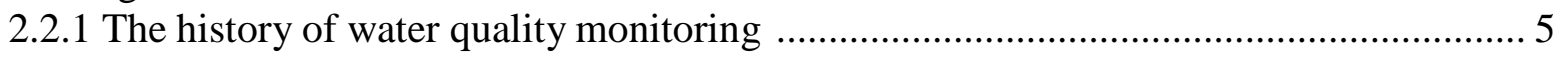

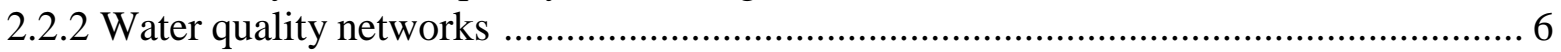

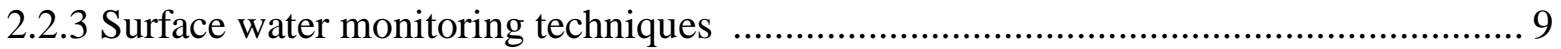

2.2.4 Indicator metrics for evaluating surface water quality .................................... 11

2.2.5 Mechanisms of contaminant dispersion ........................................................... 14

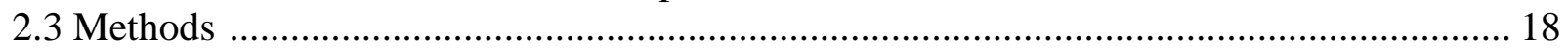

2.3.1 Field observations of surface water spill events ............................................ 18

2.2 Procedure for laboratory experiments .............................................................. 27

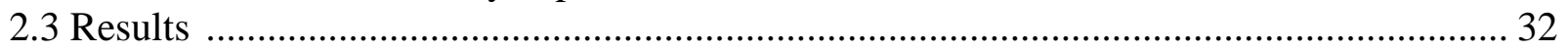

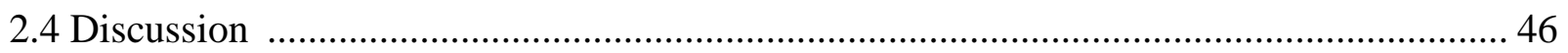

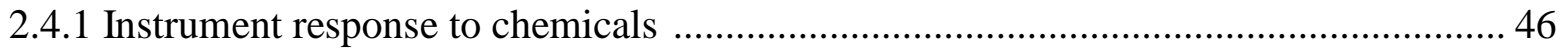

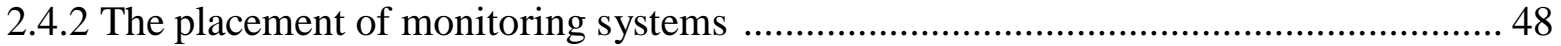

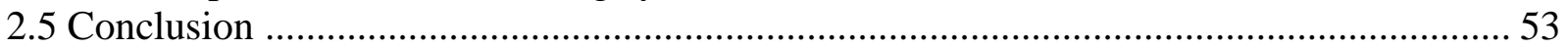

3.1 Three-Dimensional Modeling the Elk River spill in Charleston, WV ............................... 54

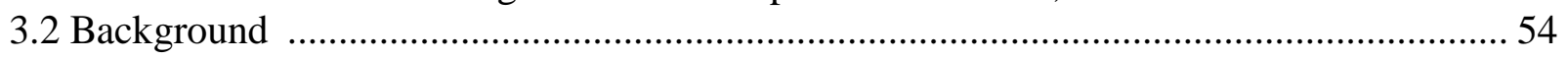

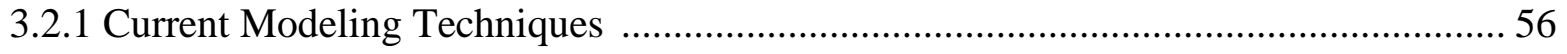

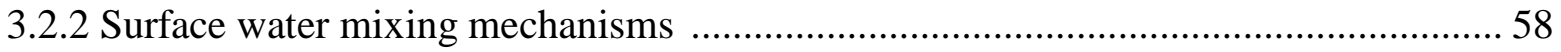

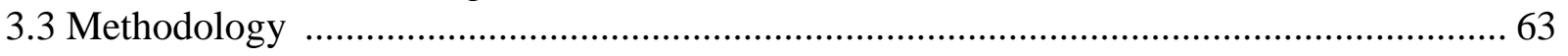

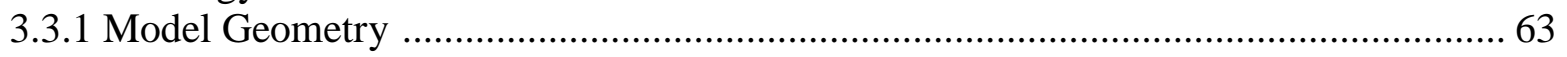

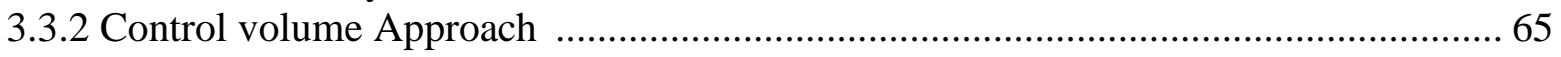

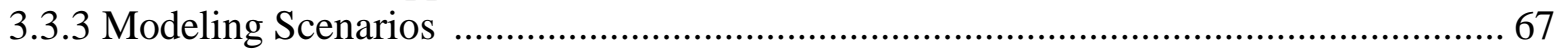

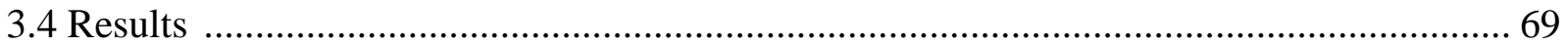

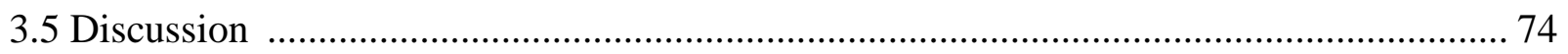

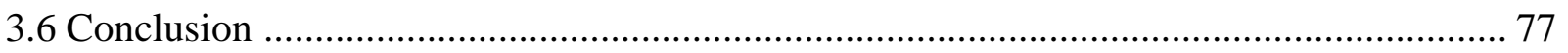

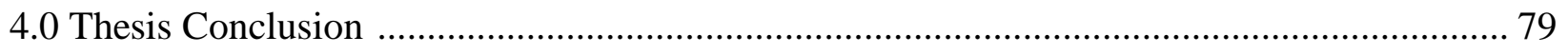

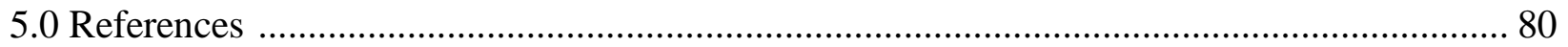

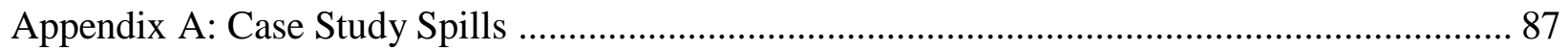

Appendix B: Laboratory Analysis Experimental Procedure .............................................. 91

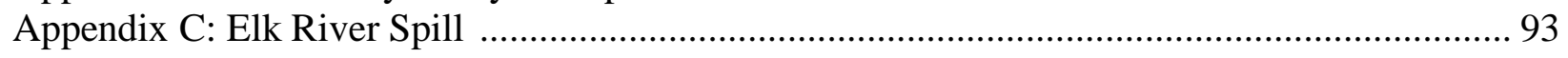




\section{Table of Tables}

Table 1 Common water quality parameters and the phenomena that affect them

Table 2 Approximate volumes of chemicals in any one hydraulic fracturing fluid composition. (USDOE 2009; GWPC 2014)

Table 3 List of contaminants reported as spills in PA DEP Notice of Violation reports; all within the SRBC RWQMN since January 2011.

Table 4 Rate of error for the Emerson et al. (2005) method to estimate the drainage area and discharge of an ungaged watershed ( $\mathrm{D}_{\mathrm{a}, \mathrm{u}}$ and $\mathrm{Q}_{\mathrm{u}}$, respectively), from data of a gaged drainage

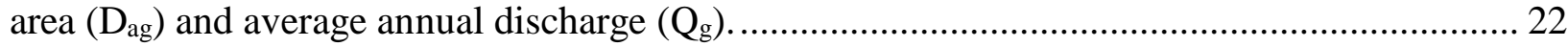

Table 5 Results of the gamma distribution calculation from USGS gaged watersheds............... 23 Table 6 Ranges of peak concentration that would be measured at the RWQMN monitoring

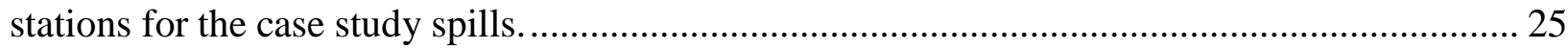

Table 7 Laboratory tested instrument ranges of operation and accuracy................................ 30 Table 4 the initial volume (L) and the total added volume of contaminant $(\mathrm{mL})$ for the laboratory

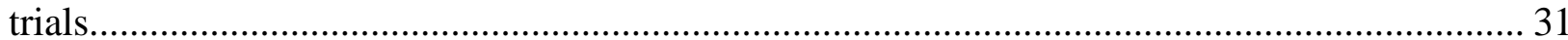

Table 9 p-value results of the paired t-test comparing the trials of the drilling mud tests ........... 33

Table 10 correlation coefficients comparing the trials of the drilling mud trials....................... 34

Table $11 \mathrm{p}$-values for the paired t-test comparing the trials of the produced water.................... 37 Table 12 Correlation coefficients for the water quality parameters across the four produced water

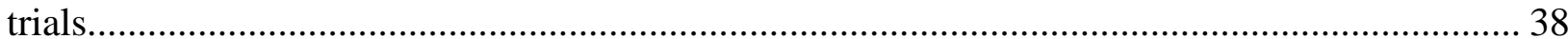

Table 13 Results from the paired t-test comparing the trials of the ethylene glycol tests ........... 42 Table 14 Correlation coefficients for the water quality parameters across ethylene glycol trials.43 Table 15 p-values and correlation coefficients between the Campbell Scientific and AquaTROLL

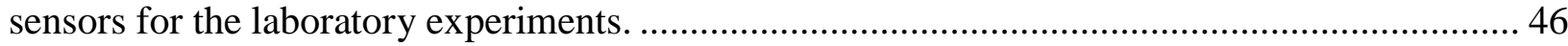

Table 16 Summary of the water quality parameters that were affected by low concentrations of contaminants. (nt.=no observed trend).

Table 20 Models currently available for simulating chemical properties and environmental fate and transport of non-aqueous-phase liquids.

Table 21 Parameter values for 1) the empirical observation, 2) the lower volatilization, 3) the less dispersion, and 4) conservative simulations.

Table A 1 Spills related to oil and gas operations within the Remote Water Quality Monitoring

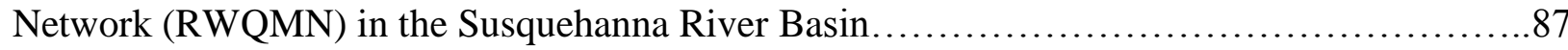

Table A 2 RWQMN watershed profiles (SRBC 2012) ................................ 88 Table A 3 Results of Emerson et al. (2005) drainage area ratio technique comparing ungaged monitoring stations to gaged monitoring stations........................................ 89

Table C 1 Chemical properties of MCHM........................................ 93 


\section{Table of Figures}

Figure 1 Map of the case study spills in the RWQMN watersheds.

Figure 2 Median peak concentration for chemical spills as a function of distance travelled in the

watershed. 26

Figure 3 Initial laboratory experiment apparatus, a) the CR-1000 probes; b) the AquaTROLL; c) deionized water and a stir bar; d) the $3.78 \mathrm{~L}$ pail; and e) instrument cords to computer communication. ${ }^{*}$ The placement of the sensors were near the pail walls and near the bottom of the pail

Figure 4 A photograph of the laboratory apparatus. a) the pail containing deionized water; b)the magnetic stirrer; c) the AquaTROLL 200; d) the CS-CR-1000 probes for $\mathrm{pH}$, dissolved oxygen, ORP and temperature/conductivity .

Figure 5 CS measurements from drilling mud experiments. a) dissolved oxygen, b) specific conductivity, c) $\mathrm{pH}, \mathrm{d}$ ) oxidation reduction potential, and e) temperature over time.

Concentration is plotted against time with a dashed line

Figure 6 AT measurements from the drilling mud experiments. a) Temperature, b) specific conductivity over time. Concentration is plotted against time with a dashed line 36 Figure 7 CS measurements from produced water experiments. a) dissolved oxygen, b) specific conductivity, c) $\mathrm{pH}, \mathrm{d}$ ) oxidation reduction potential, e) temperature over time. f) Concentration for the trials.

Figure 8 AT results from the produced water trials. a) Temperature, b) specific conductivity and c) the concentration of produced water for these trials.

Figure 9 CS measurements from ethylene glycol experiments. a) dissolved oxygen, b) specific conductivity, c) $\mathrm{pH}, \mathrm{d}$ ) oxidation reduction potential, and e) temperature over time.

Concentration is shown with a dashed line 44

Figure 10 Results from the AquaTROLL for the ethylene glycol trials. a) Temperature, and b) specific conductivity over time. The concentration is represented with a dashed line

Figure 11 The volume of the bubbles represent the peak concentration found at the monitoring station for each case study, the largest bubble being about $1.5 \mathrm{ppm}$.................................... 48 Figure 12 Little Muncy Creek $\mathrm{pH}, \mathrm{DO}$ and specific conductivity. Data collected from SRBC RWQMN. A) July 1 to July 31, 2014; B) July 3 at 12:00PM to July 5 at 4:00 PM; C) July 19 at 12:00 PM to July 21 at 4:00 PM; D) earliest arrival time predicted by empirical methods ........ 52 Figure 13 Elk River spill location at Freedom Industries, Inc. and the water way to the Charleston WV public water intake, American Water

Figure 14 Mechanisms of dispersion of an LNAPL in a control volume, represented in a crosssection is the Elk River at the American Water Systems intake

Figure 15 The cross-sections created for the model overlaid the USGS measured depths of the Elk River a) at the spill intake; b) $230 \mathrm{~m}$; c) 1000m; d) 1730m; e) $2500 \mathrm{~m}$ at the American Water

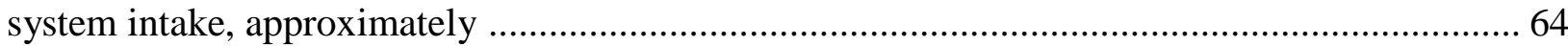
Figure 16 The Elk River geometry as it was used in the three-dimensional model. .................. 65 Figure 17 Results from the empirical model simulation at 8 hours after the spill was initiated. . 69 Figure 18 Results from the less volatilization simulation at quasi-steady state at 8 hours. ......... 71 Figure 19 Results from the decreased dispersion simulation at the quasi-steady state at 8 hours.71 Figure 20 the results of the conservative simulation at 8 hours. ......................................... 72 Figure 21 The leading edge of the $0.05 \mathrm{ppm}$ plume over time for the (i) empirical simulation, (ii) less volatilization simulation, (iii) less dispersion, and (iv) combined less volatilization and less dispersion, at a) 10 minutes, b) 1 hour, c) 2 hours, d) 3 hours e) 4 hours, and f) 6 hours. .73 
Figure 22 Cross-sections at the American Water System intake, a) 20 hours of loading at a rate of $1485 \mathrm{~kg} / \mathrm{hr}$ at quasi-steady-state; b) 20 hours of loading at a rate of $4455 \mathrm{~kg} / \mathrm{hr}$ at quasi-steadystate; c) 3 hours of loading at $9900 \mathrm{~kg} / \mathrm{hr}$ at the peak of the chemical plume.

Figure 23 Simulated concentration, averaged across the cross-section of the floating MCHM at the surface of the Elk River surface after 8 hours, from the near the spill location to the American Water Systems intake ( $\mathrm{x}=2500 \mathrm{~m})$

Figure A 1 Gamma distribution for the USGS monitored watersheds .......................90 Figure B 1 Where a) is the pail containing deionized water; b) is the magnetic stirrer; c) is the AquaTROLL 200; d) are the CS-CR-1000 probes for $\mathrm{pH}$, dissolved oxygen, ORP, and temperature/conductivity

Figure B 2 Probes associated with the CS-CR-100 system. 


\section{List of Abbreviations}

API

AT

B

C

$\mathrm{Cg}_{\mathrm{g}}$

$\mathrm{C}_{\mathrm{s}}$

Cup

CS

d

$\mathbf{D}_{\mathbf{a}}^{\prime}$

$\mathbf{D a}_{\mathbf{a}}$

$\mathbf{D}_{\mathbf{a}, \mathbf{g}}$

$\mathbf{D}_{\mathbf{a}, \mathbf{u}}$

$D_{\text {a,u-g }}$

$\mathbf{D}_{\mathbf{z}, \mathbf{a}}$

DO

$\mathbf{E}_{\mathbf{x}}$

Ey

$\varepsilon z$

g

H

$\mathbf{k}$

$\mathbf{k}_{\mathbf{G}}$

$\mathbf{k}_{\mathbf{H}}$

$\mathbf{k}_{\mathbf{d}}$

LNAPL

M

MCHM

NOV

ORP

PA DEP

Q

$\mathbf{Q}_{\mathbf{a}}^{\prime}$

$Q_{\mathbf{a}}$

Qg

Qu

RWQMN

S

SRBC

t

$\mathbf{T}_{\mathbf{p}}$

$\mathbf{U}$

$\mathbf{u}^{*}$

UNESCO

USCG
American Petroleum Institute

AquaTROLL 200

average channel width

concentration

saturation concentration of chemical in the gaseous phase

saturation concentration of the chemical in the liquid phase

peak concentration

Campbell Scientific CR-1000 Data-logging System

distance traveled

empirical value representing average drainage area

drainage area

gaged stream drainage area

ungaged stream drainage area

ungaged stream drainage area as predicted by Emerson et al.'s method (2005)

rate of volatilization

dissolved oxygen

longitudinal dispersion coefficient

lateral dispersion efficient

vertical dispersion coefficient

acceleration due to gravity

average channel depth

skew

gas phase mass transfer

Henry's law constant

mass transfer coefficient

light non-aqueous phase liquid

molecular weight of the chemical of interest

4-Methylcyclohexanemethnol

Notice of Violation

oxidation reduction potential

Pennsylvania Department of Environmental Protection

instantaneous river flowrate

empirical value representing average annual flowrate

average annual river discharge

gaged stream average annual flowrate

ungaged stream average annual flowrate

Remote Water Quality Monitoring Network

channel slope

Susquehanna River Basin Commission

time

travel time of peak concentration

average channel velocity

shear velocity

United Nations Educational, Scientific and Cultural Organization

United States Coast Guard 


$\begin{array}{ll}\text { USGS } & \text { United States Geological Survey } \\ \text { US EPA } & \text { United States Environmental Protection Agency } \\ \mathbf{V}_{\mathbf{p}} & \text { velocity of peak concentration } \\ \mathbf{V}_{\text {wind }} & \text { velocity of wind } \\ \mathbf{V}_{\text {curr }} & \text { velocity of river current } \\ \mathbf{X} & \text { longitudinal direction } \\ \mathbf{Y} & \text { transverse direction } \\ \mathbf{Z} & \text { elevation }\end{array}$




\subsection{Introduction}

\subsection{Background}

One of the risks associated with industry and production of materials is the use of chemicals and the possibility that these chemicals may be lost to the environment. The chemical sometimes poses physical hazard to the living things with which it comes in contact. For these reasons, regulations such as the Clean Water Act and Toxic Substances Control Act dictate best management practices and include requirements to report and to control these materials (US EPA, 2015a). When an industry spills liquid waste or chemicals into a moving body of water, the water transports a bulk of the chemical along its flow path. Eventually, the entering contaminant becomes diluted to the point of no-detection due to dispersion (Jobson 1996) and an increasing distribution volume. At times the loading rate of contaminants can cause downstream water quality to be greatly affected. Large spills have a combination of negative effects on ecology or society residing within its area of influence. Catastrophic events cost more than the expenses of remediation: the loss of public trust and damages to reputation can affect the future business of responsible parties (Gunningham et al. 2006).

There is a history for extractive industry, particularly mining, to have a long-term effect on water quality. For example acid mine drainage affects aquatic habitat and can impair water such that is inadequate for recreational use (Younger 2001). Another example, investigated in depth in this study, is the oil and gas industry, where development and operational phases involve extensive disturbances and management of sediment and water. Chemicals for operations are transported and stored in trucks or above ground storage vessels, and remain in concentration until being added to the fracking fluid right before injection (King 2012). Unconventional resource development also produces millions of gallons of wastewater at each well. Regulations 
restrict the release of wastewaters to the environment, and some state regulations require the wastewater to be collected and contained in a series of tanks or pits or injected into formations (NETL 2009). The processes involved with the storage and transport of these fluids and chemicals pose an inherent risk of spills to the environment surrounding the well-pad.

River organizations, such as non-profits ("Friends of" groups), state and federal environmental protection agencies are concerned that oil and gas development would impede the quality of their watershed, so they deploy sensors to monitor water quality. An example is the Susquehanna River Basin Commission's (SRBC) Remote Water Quality Monitoring Network (RWQMN) where electronic monitoring technology has been deployed in tributaries of the tristate watershed. The networks are to observe whether natural gas industry and other activities cause adverse impacts on water quality and to hold these industries accountable (SRBC 2013). The method of observation is to place electronic water quality monitoring equipment at the mouths of small watersheds. In practice, continuously monitoring instruments measuring specific conductivity are the most common. Additional, more expensive suites include dissolve oxygen, $\mathrm{pH}$, and oxidation reduction potential. The SRBC also takes stream flow measurements, macroinvertebrate assessments and a suite of chemical analysis from grab-samples each year (SRBC 2014). Developing a means to detect spills early and to mitigate the spill effects downstream may keep accidents from developing into disaster. The technology is already widely used by watershed stakeholders, but a method to interpret the data in a useful manner is not an established practice.

At times disasters indicate vulnerabilities that require better preparedness measures. An example of this is the disaster that occurred in Charleston, WV on January 9, 2014. This event consisted of a failure of an above-ground storage tank that resulted in a loss of over 10,000 
gallons of 4-Methylcyclohexanemethanol (MCHM), a chemical used in coal processing (Memmot 2014). The spill drained into the Elk River, and the chemical was transported past a water intake plant in Charleston, WV. The public water system distributed the chemical into the city, affecting over 300,000 residents. The chemical plume also travelled through the watershed into the Kanawha River and narrowly was prevented from affecting the Cincinnati public water system in Ohio (Cooper 2014).

\subsection{Goals and Objectives}

This research characterizes two approaches to identifying the risk associated with surface water spills: (1) determining the necessary criteria for establishing a continuous monitoring system to detect surface water spills on watersheds with an area of less than $200 \mathrm{mi}^{2}$, and (2) modeling the distribution of chemicals within surface water immediately downstream from a surface spill event. The specific objectives include the following:

1) Determine whether commercially available continuous sensors are effective in detecting pollution incidents related to oil and gas operations;

2) Develop a three-dimensional model of the MCHM spill in the Elk River that incorporates extended chemical loading, 2-phase flow, dispersion and diffusion in an irregular channel, and the effects of volatilization and chemical properties.

The results from this study will ultimately provide information to help develop programs for spill detection and mitigation. 


\subsection{Study Design}

For the "instrument assessment for detecting surface water spills" study (i.e. objective 1), example spills were identified from Pennsylvania Department of Environmental Protection (PA DEP) Oil and Gas Compliance Reports. Empirical models were used to determine the maximum concentration that can be expected when a spill reaches water quality monitoring stations. These concentrations were tested in an apparatus using field equipment typically deployed for continuous water quality monitoring. The detection levels and instrument response were evaluated.

For the Elk River Spill model, the river geometry was digitized based on cross-section data collected by the United States Geological Survey (USGS). A finite-element method was applied to simulate dispersion and chemical properties within control volumes. The extent of contaminant distribution was identified and the model was optimized to fit measured concentrations days after the spill. The parameterization was justified by environmental phenomena and a synthesis of observations from current literature. 


\subsection{Assessing the use of instruments for detecting surface water spills}

\subsection{Background}

\subsubsection{The history of water quality monitoring}

Water quality monitoring has evolved from a regulatory effort to manage the environmental costs from societal development (Ward et al. 1990). The accumulating knowledge of water quality and how it affects quality of life can be followed through early history in water quality management. Past issues have been: controlling debris and foul odors for waterway navigation in the Rivers and Harbors Act of 1899; maintaining water quality as it affects public health in the Public Health Service Act of 1912; and pollution control to protect source water resources in the Federal Pollution Control Act of 1956 (Ward et al. 1990; USEPA 2012a). With the amendments in 1972, the Federal Pollution Control Act was amended and renamed the Clean Water Act. Important innovations in the Clean Water Act include defining water quality standards and identifying the beneficial uses for water in Section 303(c) (USEPA 2012a).

The regulatory demand for maintaining water quality motivated the measurement and analysis of certain water parameters as indicators of water quality. States and water quality managers developed water quality standards based on the established uses of water (USEPA 2012a). Parameters such as dissolved oxygen, temperature, and turbidity were formulated as indicators of allowable water quality by sanitary engineers (Sanders and Ward 1979). At the time of the Federal Pollution Control Act, focus was placed on the acquisition and analysis of data (Haney and Schmidt 1958; Ward et al. 1990; USEPA 2012a).

The nationwide approach to these new regulations caused the collection of data to become an end in itself. Criticisms of the lack of information and the lack of statistical observations began to surface in the 1970s and 1980s (National Academy of Sciences 1977). The 
complexity of spatial versus temporal trends, and the myriad of variable effects in physical, chemical and biological parameters were coming to light at the time (American Water Resources Association 1998).

USGS and U.S. Environmental Protection Agency (USEPA) endeavored to improve the capacity of water quality data collection by developing national water quality monitoring methods. Congress created the National Water-Quality Assessment program to be managed by USGS (Hirsch et al. 1988) and the USEPA developed standards in order to accelerate compliance, implementation and interpretation of national water quality standards as described in the 1987 Water Quality Act (USEPA 2012a). These comprehensive approaches culminated in methods to develop water quality monitoring systems that can provide useful information for decision-making and risk mitigation of emerging contaminants.

\subsubsection{Water quality networks}

A water quality network consists of a series of sampling and reporting procedures to monitor water quality. Such networks could consist of a random spot check in an industrial process, known as “ambient monitoring” (Stednick and Roig 1989) or could be a series of fixedsites where sampling continues indefinitely, known as "fixed station quality monitoring" (Ward et al. 1990). Fixed station monitoring can be used to describe water quality over a large region and over a long period of time. A national example of a fixed station monitoring program is the USGS National Water Information System, which collects data from over 1.5 million sites across the United States and has been in operation for over 100 years. The data include water level, water quality and physical parameters at 15- to 60- minute intervals (USGS 2015).

The limiting factors on the scope of a water quality monitoring network are the cost equipment, the analytical laboratory techniques available, and the man-hours required (USEPA, 
2006). Inferior design practices are based on the ease of access for sample collection locations, the laboratory capability for the type of grab samples analysis, and the agency budget and other management tasks for the sampling frequency (Ward et al. 1990). When these priorities supersede the objective and purpose of the monitoring program, it is difficult to generate meaningful information. Lack of documentation and seemingly haphazard organization within poorly planned water monitoring networks will cause the watershed networks to be "data rich" and "information poor". Over time, the purpose of a water quality monitoring network may be obscured and systems may be easily cut when budgets are tight (Ward et al. 1990). Instead, a monitoring network is more likely to be successful when the parameters and frequency of sampling is clearly motivated by the program objectives (Dixon and Chiswell 1996; Sanders and Ward 1979).

Because of the initial struggles to adopt a national method for monitoring, there has been much emphasis for water quality monitoring systems to have defined objectives and purpose (Ward et al. 1990; Strobl et al. 2006). The monitoring program objectives vary based on the intended use of water. Some networks are generated to confirm waste water treatment, such as in industrial waste streams. In these instances water quality parameters such as chemical oxygen demand, fractionation of organic nitrogen, and total organic carbon are used both in the initial system design and as an evaluation tool for system operation (Tchobanoglous et al. 1991). Other routine monitoring objectives are to locate nonpoint source pollution, to confirm compliance to National Pollutant Discharge Elimination System (NPDES) permits, or to report quality and general trends over time to the public (USEPA 1999; USEPA 2012a; SRBC 2014).

Water quality monitoring systems are developed with a combination of in-stream sensors at fixed locations, synoptic sampling and observation of the surrounding watershed (Hirsch et al. 
1988). Only after the objective is defined should the logistics of sampling frequency and measured parameters be determined (Dixon and Chiswell 1996). The samples generated during the water quality monitoring process should be statistically evaluated to characterize water quality and to prevent any bias in interpretation (Watershed Academy 2006). In recent years, water quality monitoring networks have been used to observe phenomena of regulatory concern. Some examples include eutrophication of water bodies near regions in need of nutrient management (i.e. above and below major sewage facilities) (Kelly 1998), total maximum daily loads based on environmental stressors (Davies and Tsomides 2002), and erosion from development (Ward et al. 1990; Strobl and Robillard 2008; USEPA 2012a).

Water quality monitoring systems have expanded with the creation of real-time remote monitoring systems. Remote monitoring is a synthesis of in-stream measurements and wireless telecommunications that generate and distribute water quality information over great distances (Telliet et al. 2002). The USGS originally began using satellite telemetry for collecting hydrologic data (stream flow and rain fall) in the 1970s (Turner and Woodham 1980); the organization found that remote data collection greatly reduced the demands on human resources. Now, with the development of sensors and computer interfaces, it is possible to combine instream measurements with remote sensing programs to model hydrologic systems (Teillet et al. 2002). For example, the Florida Marine Research Institute has a remote water quality monitoring system called the MERHAB Autonomous Research Vessel (MARVIN), which measures water quality parameters, nutrients, hydrologic and meteorological data, with samplers that could be remotely triggered at certain thresholds or events. This technology identified an algal bloom as it was developing in July 2002, and the high-resolution data collected at the time contributed to understanding the environmental and hydrologic factors that contribute to biomass production 
(Paerl et al. 2004). As computer engineering, sensing and transduction technology improves, remote-real time monitoring systems becomes increasingly viable for land management and pollution detection (Telliet et al. 2002; Rodriguez-Mozaz et al. 2004).

\subsubsection{Surface water monitoring techniques}

At the time of Clean Water Act legislation, field observations focused on spot-sampling as an established method to acquire water quality data (Ward et al. 1990). In spot sampling, water is sampled at a prescribed location and time, and the sample is sent to a laboratory for pollutant analysis (Sanders and Ward 1979). The use of laboratory analysis, with proper quality assurance, provides researchers consistent results and high resolution information about the particle constituents and their concentration (Ward et al. 1990; Hirsch et al. 1988; Smith and McBride 1990)

Monitoring frequency depends on the phenomena being considered. For observing baseline information, particulate measurements once a year is often sufficient. For monitoring ecosystems or habitat, it may be as frequent as 12 times per year (UNESCO 1996). For hydrologic measurements, the frequency of monitoring is based on the residence time of water in that particular water body (e.g. a stream, large river, or lake) (UNESCO 1996). Spot sampling is appropriate for monitoring general trends, but does not have the high resolution needed to identify random, discrete events. The nature of synoptic sampling is to focus on an area for 1-2 weeks (Dixon and Chiswell 1996). In this time, even a conservative contaminant will disperse and eventually pass in a moving body of water (Jobson 1996). Spot-sampling is incapable of measuring temporary variations, and the necessity for a substantial field set-up or laboratory transport means that it cannot be analyzed rapidly (Pellerin and Begamaschi 2014). Real-time measurement is preferred under time-sensitive, emergency situations, such as during a 
catastrophic spill or in conditions that may threaten human health (Grayman and Males 2002; Rodriguez-Mozaz et al. 2004; Allan et al. 2006; Telci et al. 2009).

Spills into surface water bodies are likely to be accidental, and therefore it is necessary to monitor the water quality continuously over time. If electronic water quality monitoring equipment is used to detect pollution events, the chemical must impact field parameters measured by the sensors deployed, the spills must occur in the drainage areas of monitored streams, and the contaminant must be concentrated to a degree that causes measurable change in water quality (Pellerin and Begamaschi 2014). The ability to detect changing water quality variables is dependent on the sample rate and the sensitivity of the equipment used. If the equipment is not sensitive enough, if the detectable portion of the chemical plume passes by too quickly, or if the natural variations of water quality change masks the chemical signal, then the chemical change in water will not be observed (Pellerin and Begamaschi 2014).

Emerging technologies address the issues of timely measurement. Electronic sensors may be placed in-stream and are capable of nearly continuous (with a sampling frequency of seconds or minutes) and rapid interpretation of data (Allan et al. 2006; Strobl and Robillard 2008). Continuous monitoring techniques are advantageous for avoiding the bias found in monthly sample collection. As more samples are collected, the observations are more rigorously representative of the water quality (Pellerin and Begamaschi 2014). Electronic sensors include biological early warning systems, passive samplers, biosensors and optical sensors (Allan et al. 2006). Optical sensors measure the ability of a dissolved or suspended material to absorb, fluorescence, or scatter light (Pellerin and Begamaschi 2014). The amount of light absorbed or the wavelength at which is it scattered indicates unique material properties such as type, size, and concentration (Pellerin and Begamaschi 2014). 
Biosensors have shown great advancement in the number of environmental contaminants detected. The versatility in the use of biosensors has been supplemented with scientific research on biomarkers, which are measureable substances in organisms that indicate a disease, infection or environmental exposure. Biosensors can measure the presence of these substances to determine either contaminant toxicity or the tendency of a contaminant to disrupt endocrine activity (Rodriguez-Mozaz et al. 2004). The environmental stress due to chemical or thermal loading can be identified by the presence of certain proteins created by microorganisms (Allan et al. 2006) or by a variety of specific receptors for DNA, whole-cell, molecules, et cetera (Rodriguez-Mozaz et al. 2004). The investigation of toxin response can be extrapolated to the molecular, organism or ecosystem level (Peakall 1994).

Passive samplers adsorb pollutants and measure the concentration of the contaminant by first order kinetics calculations (Allan et al. 2006). These samplers, as well as biosensors, eliminate the need to collect grab-samples, and can process pollutant analysis while remaining in the stream. These passive samplers, biosensors, and optical sensing technology can be deployed for months at a time to collect data at frequencies and durations that was not possible 40 years ago (Pellerin and Begamaschi 2014).

\subsubsection{Indicator metrics for evaluating surface water quality}

Selecting which indicators to monitor are just as important as selecting monitoring locations during water quality monitoring system design (Dixon and Chiswell 1996; Sanders and Ward 1979). The monitoring sites are selected to properly represent the water quality "population" under observation (Ward et al. 1990). For example, a monitoring station may be placed above and below a sewage intake. The station above the confluence of the sewage intake observes the baseline water quality while the second station gathers information about the water 
quality after the influence of sewage (Kelly 1998). Several more stations may be placed downstream if water quality varies and if these parameters are relevant to the water quality monitoring system objective (Ward et al. 1990). As for what should be measured, a wise selection of indicators allows for comprehensive baseline observations while operating on limited resources (Ward et al. 1990). Indicators may be biological, chemical, or physical. Indicators are used by the researcher to evaluate whether the water quality meets the standards for its intended use (USEPA 2003). When tasked with monitoring the quality of a body of water, researchers have an option to use sensors that are non-specific that provide data about the water quality that can be extrapolated to environmental conditions (Sanchez et al. 2007). The parameters often used are described in Table 1. 
Table 1 Common water quality parameters and the phenomena that affect them

\begin{tabular}{|c|c|c|}
\hline $\begin{array}{l}\text { Water Quality } \\
\text { Parameter }\end{array}$ & Indicator of & Meaning of measurement \\
\hline $\begin{array}{l}\text { Turbidity } \\
\text { (USEPA 2015b) }\end{array}$ & $\begin{array}{l}\text { - Erosion } \\
\text { - Runoff } \\
\text { - Algal growth } \\
\text { - Animal activity } \\
\text { - Waste discharge. }\end{array}$ & $\begin{array}{l}\text { Low indicates best water quality } \\
-\quad 1 \text { NTU: clear mountain stream } \\
\bullet \quad 10 \text { NTU: Large river on a dry day } \\
\text { - } \quad 100 \text { s+ NTU: Runoff event } \\
\text { High indicates presence of sediments. }\end{array}$ \\
\hline $\begin{array}{l}\mathrm{pH} \\
\text { (USEPA 2015b) }\end{array}$ & $\begin{array}{l}\text { - Waste discharge } \\
\text { - Geologic effects } \\
\text { (AMD) } \\
\text { - Photosynthetic } \\
\text { activity. }\end{array}$ & $\begin{array}{l}\text { Acidic waters increase the mobility of toxic elements and } \\
\text { compounds } \\
\text { - } \quad 1-5 \mathrm{pH} \text { : acidic conditions } \\
\text { - } \quad 6.5-8.2 \mathrm{pH} \text { : optimal for supporting aquatic life } \\
\text { - } \quad 9-14 \mathrm{pH} \text { : basic conditions }\end{array}$ \\
\hline $\begin{array}{l}\text { Dissolved oxygen } \\
\text { (DO) } \\
\text { (Watershed council } \\
2015 \text { ) }\end{array}$ & $\begin{array}{l}\text { - Biological activity } \\
\text { - Chemical oxidation }\end{array}$ & $\begin{array}{l}\text { DO saturation is dependent on temperature and fluctuates } \\
\text { diurnally and seasonally. } \\
\text { - } \quad<2 \mathrm{mg} / \mathrm{L} \text { : hazardous to aquatic life, may be caused by } \\
\quad \text { excessive nutrients and respiration (eutrophication) } \\
\text { - } 5-7 \mathrm{mg} / \mathrm{L} \text { : optimal for supporting aquatic life } \\
\text { Higher values - saturation: ideal water quality }\end{array}$ \\
\hline $\begin{array}{l}\text { Conductivity } \\
\text { (Watershed Council } \\
\text { 2015; USEPA } \\
2015 \text { b) }\end{array}$ & - Dissolved ions & $\begin{array}{l}\text { A steady increase is an indicator of pollution and dissolved } \\
\text { substances } \\
\text { - } \quad 0-3 \mu \mathrm{S} / \mathrm{cm} \text { : Rainwater or distilled water } \\
\text { - } \quad 50-1,500 \mu \mathrm{S} / \mathrm{cm} \text { : Rivers of the US } \\
\text { - } \quad 10,000 \mu \mathrm{S} / \mathrm{cm} \text { : Industrial waste streams } \\
\text { - } \quad 50,000 \mu \mathrm{S} / \mathrm{cm} \text { : Seawater }\end{array}$ \\
\hline $\begin{array}{l}\text { Temperature } \\
\text { (USEPA 2015b) }\end{array}$ & $\begin{array}{l}\text { - Weather } \\
\text { - Waste discharge } \\
\text { - } \text { Runoff } \\
\text { - Groundwater }\end{array}$ & $\begin{array}{l}\text { Controls rates of biological and chemical processes, controls } \\
\text { solubility of oxygen and other compounds. } \\
\text { Varies by climate and location. } \\
\text { - } \quad 0^{\circ} \mathrm{C} \text { : freezing temperature } \\
-100^{\circ} \mathrm{C} \text { : Industrial waste streams }\end{array}$ \\
\hline
\end{tabular}

Some parameters, such as conductivity and turbidity are not specific enough to indicate the exact cause of pollution, but many contamination scenarios will cause a change in these water quality parameters. USEPA has presented a case study for this in regards to timber industry operations having an impact on source water. The water supplies in Salem, OR were traditionally treated with slow-drain sand filters, and events such as landslides or storm-induced erosion from timbering had caused complications in the municipality's water distribution. Turbidity monitoring systems were developed by the US Army Corps of Engineers and local watershed stakeholders, and this water quality parameter proved to be a strong indicator for 
water pollution. The system allowed for the water intake to be sufficiently forewarned of the non-ideal conditions. Preventative measures were in place to use an alternate water source and to initiate a special water collection procedure (USEPA 1999).

Researchers have developed indices that use a combination of measured parameters to identify vulnerable water resources (Bharti and Katyal 2011). Indices allow for physical parameters and intended uses to be combined into holistic water quality evaluations, such as an "ideal" or "not ideal" quality for a particular use. Indices can be used as a quantitative measurement of environmental impact during a remediation project or as an indicator of a changing trend in water quality (House and Newsome, 1989). When these methods of observation are applied to new industries, such as natural resource development, it is necessary to know what water quality variables are appropriate for developing a water quality index.

\subsubsection{Mechanisms of contaminant dispersion}

The concentration of a chemical as it travels through a surface water body is affected by advection and mixing due to turbulence and dispersion (Jobson 1996). As the chemical travels downstream, lateral dispersion becomes less influential as the water column becomes completely mixed. Longitudinal dispersion continues to have an effect, creating a larger more dispersed plume.

It is unlikely that a continuously monitoring sensor would be placed immediately downstream of a random, accidental spill. Instead, the sensor measures the accumulating discharge of the entire upstream watershed. The greater the distance a contaminant is transported the more diluted it becomes, from both factors of mixing (Jobson 1996) and from the increasing discharge of the increasing watershed drainage area. Because discharge varies throughout the year, discharge $(\mathrm{Q})$ is a random variable with a distribution proportional to annual flow in a 
watershed. Flow-rate greatly contributes to the diluting capacity of a body of water; lower flows will allow greater concentrations of contaminant to persist as dilution is limited.

Longitudinal dispersion creates a leading edge and a trailing edge of a plume. These portions of the concentration curve are less than the middle maximum, called the peak concentration. The peak concentration of the spill can be estimated based on the time it takes to travel to the sensor location (Jobson 1996). The peak concentration can be estimated with very limited data. The average velocity and travel time are calculated by the average annual discharge, a technique available from empirical observations (Jobson 1996).

\subsubsection{Potential impacts of oil and gas operations on water quality}

Unconventional gas wells generate solid and fluid waste streams, including flow back, precipitates, drilling fluids and drill cuttings (Ziemkiewicz et al. 2014a). There are 2 to 4 million gallons of water needed to fracture a well, and the fracture fluid is approximately $99.51 \%$ water and sand; and $0.49 \%$ additives (USDOE 2009). After drilling, approximately $10 \%$ to $30 \%$ of the volume of injected fluid returns to the surface. The initial water that returns to the water is called flow back water. Once the well begins to produce gas, the water is referred to as "produced water" (Vidic et al. 2013; Lutz et al. 2013). The flow back and produced water have an inorganic fraction composed of $\mathrm{Na}, \mathrm{Cl}, \mathrm{Ca}, \mathrm{Mg}, \mathrm{Br}, \mathrm{Ba}$ and $\mathrm{Sr}$. Concentrations of total dissolved solids up to $200 \mathrm{~g} / \mathrm{L}$ have been documented (Ziemkiewicz, et al. 2014a). In the produced waters of the Appalachian basin, benzene and naturally occurring radioactive materials were consistently found in excess of drinking water standards. Concentrations are variable, but tend to increase as the flow back cycle continues over time (Haluszczak et al. 2013; Ziemkiewicz et al 2014a).

Drilling fluids are necessary component of the drilling process to keep the broken formation from clogging the well bore and to prevent the collapse of the well bore. In hydraulic 
fracturing, fluid pressure is the mechanism that cracks the target formation. More and more fluid is used to propagate cracks and sand props the cracks open. To ensure sufficient volumes of fluid during drilling and hydraulic fracturing, drillers excavate containment ponds or storage pits to hold water; in urban areas, where space is limited, storage tanks are used (USDOE 2009). In West Virginia, the fluid that flows back from hydraulic fracturing is disposed either through reuse $(78 \%)$ or injected into wells $(22 \%)$; of the fluid to be injected, forty-three percent is sent out of state. The lag of time between flow back generation and disposal imposes the risk of fluid loss in transport and storage (Downstream Strategies 2013).

The volume and type of chemicals used in hydraulic fracturing fluid varies from among operations (Soeder et al. 2013). The geochemistry of the formation, the quality of the water, and the operator's preferences determine the composition of the fracturing fluid. The chemicals are added on-site during the hydraulic fracturing process. Before injection, chemicals (e.g. biocides, corrosion inhibitors, friction reducers, etc.) are stored on site either in trucks or above ground storage tanks, sometimes in significant volumes (King 2012; Soeder et al. 2013). Examples are listed in Table 2 (GWPC 2014).

Table 2 Approximate volumes of chemicals in any one hydraulic fracturing fluid composition. (USDOE 2009; GWPC 2014)

\begin{tabular}{ccc}
\hline $\begin{array}{c}\text { Hydraulic Fracturing Additive (Example } \\
\text { chemical) }\end{array}$ & $\begin{array}{c}\text { Average \% of } \\
\text { Total Fluid } \\
\text { Volume }\end{array}$ & $\begin{array}{c}\text { Approximate Volume } \\
\text { Needed per Fracture* } \\
\text { (gallons) }\end{array}$ \\
\hline $\begin{array}{c}\text { Gellant (Guar gum or ethylene glycol) } \\
\text { Friction Reducer (Polyacrylamide or ethylene } \\
\text { glycol) }\end{array}$ & 0.5 & 10,000 \\
Biocide (Glutaraldehyde) & 0.05 & 1,000 \\
Water & 0.001 & 20 \\
& 99 & 2 to 5 million \\
\hline
\end{tabular}

*Calculated based on 2 MG hydraulic fracturing fluid.

In a study of PA DEP Notice of Violation reports, there have been 31 significant spills (>9.5 barrels) over the course of 7000 well spuds and 4000 completed wells from 2005 to November 2013. The incidents included fuels (1), fracking chemicals (7), produced fluids (9), 
sediments (5), and drill cuttings (9). The violations were due to vehicular accidents or pipe failure, well blowouts, and leaky storage containers (Brantley et al. 2014).

Spills may occur from pipe ruptures, storage tank failure, loss of integrity of the surface storage liner, or any number of accidents. (Ziemkiewicz et al. 2014b). If these accidental spills are not contained, aqueous chemicals will infiltrate the soil and may possibly drain into a nearby stream (Winter et al. 1998). This phenomenon occurs because elevation directs free flowing material, or runoff, from anywhere within a watershed basin and transports it to the mouth, or lowest point, of the watershed. Eventually the runoff combines with groundwater seeping to the surface and accumulates as streams and water bodies.

When traveling in a moving surface water body, contaminants are mixed along the water column by mechanisms of dispersion (Jobson 1996). The mixing mechanisms create a diluted plume of chemical which is carried downstream. The hypothesis is that water quality variables can be detectably impacted by a spill in a drainage catchment, especially in the case of spills that occur close to the surface water system. Chemical spill events that have a chemical disparity from the surface water may be detectable by common water quality parameters. Electronic water quality monitoring would then be a valid tool for pollution detection.

There has been significant field research for hydrologic phenomena to estimate dispersion (Jobson 1996; Emerson et al. 2005). Tracer studies were used to measure the dispersion due to mixing in streams and rivers. Drainage area, flow-rate and velocity are particular variables that determine the magnitude of dispersion. Pollutant travel time and longitudinal dispersion can be derived based on average annual flows and physical characteristics of the basin involved (Jobson 1996). Some measurements, like river stage and discharge are available from USGS water monitoring stations (USGS 2015). Sometimes, data 
about physical characteristics of drainage basins are not available or difficult to acquire. Models can determine physical and environmental relationships from spatial data with great accuracy. Stream paths, accumulated flow, and average stream velocity can be determined from readily available data such as digital elevation models (Strager 2012).

The objective for this study is to determine how commercially available continuous monitoring sensors would respond to pollution events. First, the peak concentrations of contaminants from surface water spills in monitored watersheds were estimated, and then the ability of in-stream instruments to detect a change in water quality due to the peak concentration was tested in a laboratory. This information can be applied to design water quality networks to detect surface water spills in order to mitigate risks to human health and to better enforce contaminant control.

\subsection{Methods}

\subsubsection{Field observations of surface water spill events}

\section{Identifying case studies}

To determine a range of concentrations for laboratory testing, twenty-two spill events were selected from the PA DEP's Oil and Gas Compliance Report database for review. This database provides the date, the American Petroleum Institute (API)-number, a description of the location and nature of the incident. These spill events occurred within the SRBC Remote Water Quality Monitoring Network (RWQMN) since January 2011 and were chosen based on whether the incident report included comments of the contaminant spilled and approximate volume. These parameters are necessary for determining a peak concentration and investigating water quality parameters that would be affected. 
It was found that the volumes and type of chemicals spilled for the case studies (Table 3) were consistent with previously published findings (Brantley et al. 2014). Produced water and drilling mud are sometimes spilled in large volumes, exceeding 30 barrels and sometimes greater than 100 barrels of contaminant (Brantley et al. 2014). The API locations listed for each notice of violation were recorded, and the GPS coordinates for these locations were projected on an ArcGIS map over the RWQMN watersheds (Figure 1).

Table 3 List of contaminants reported as spills in PA DEP Notice of Violation reports; all within the SRBC RWQMN since January 2011.

\begin{tabular}{cccc}
\hline $\begin{array}{c}\text { Hydraulic } \\
\text { Fracturing } \\
\text { Addditive }\end{array}$ & Purpose & $\begin{array}{c}\text { Average Volume, } \\
\text { [Maximum volume] } \\
\text { (barrels) }\end{array}$ & $\begin{array}{c}\text { Number of Incidents } \\
\text { in Study Area }\end{array}$ \\
\cline { 1 - 2 } $\begin{array}{c}\text { Drilling Mud } \\
\text { Produced Water } \\
\text { Diesel Fuel }\end{array}$ & $\begin{array}{c}\text { Used to keep the bit wet during drilling } \\
\text { Effluent from the well after drilling } \\
\text { Powers equipment and vehicles on the } \\
\text { well pad }\end{array}$ & $\begin{array}{c}34[104] \\
34[150]\end{array}$ & 4 \\
$\begin{array}{c}\text { Corrosion inhibitor } \\
\text { (i.e. ethylene glycol) } \\
\text { Mixture of mud, } \\
\text { water and/or fuel }\end{array}$ & $\begin{array}{c}\text { Used as a winterizing agent or to prevent } \\
\text { pipe deterioration }\end{array}$ & $0.5[0.5]$ & 12 \\
\cline { 1 - 2 } & $\begin{array}{c}\text { Effluent from the well or from an } \\
\text { accidental spill }\end{array}$ & $0.8[0.9]$ & 1 \\
\hline
\end{tabular}




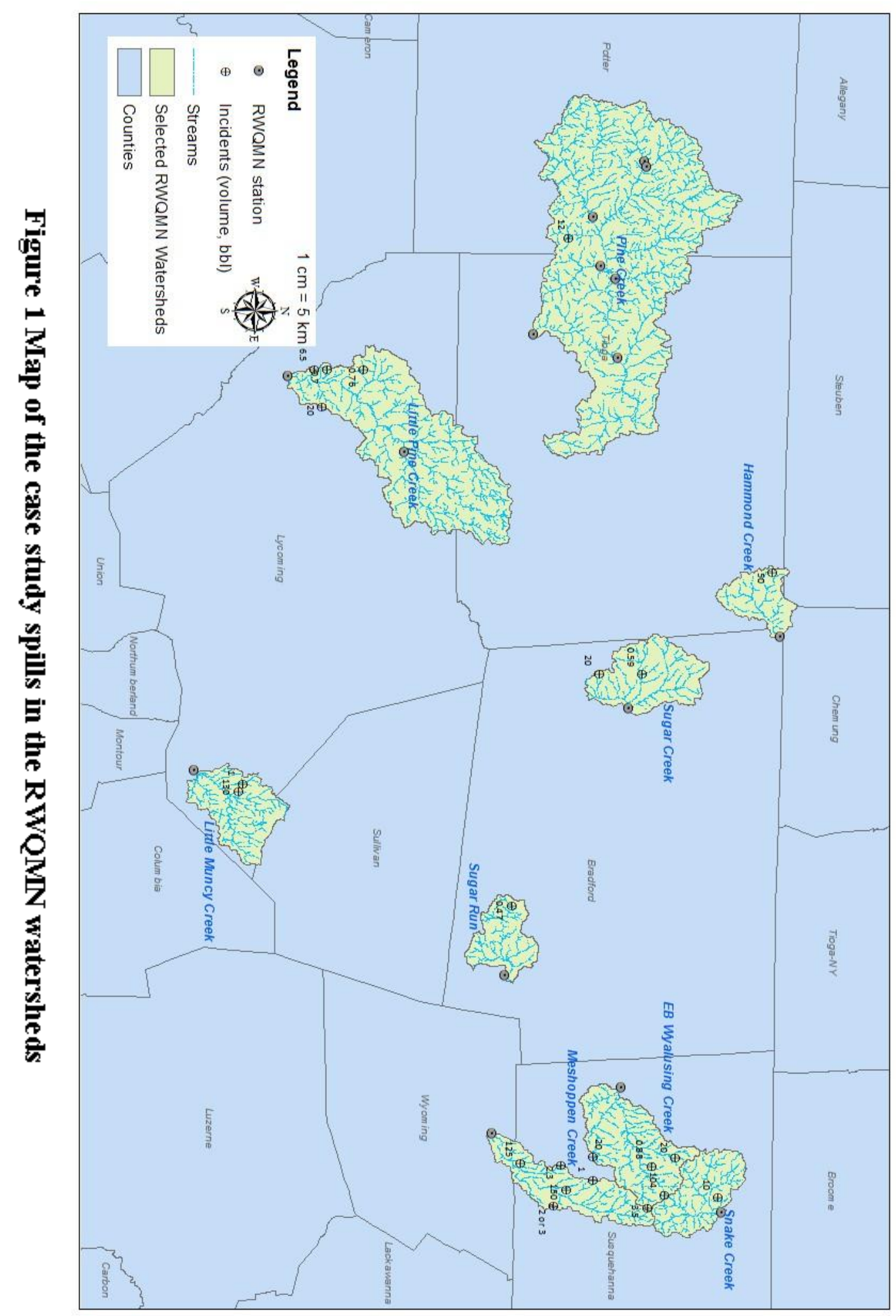




\section{Estimating a range of flow-rates for the ungauged watersheds}

The spatial variables of drainage area $\left(\mathrm{D}_{\mathrm{a}, \mathrm{u}}\right)$ and average annual discharge $\left(\mathrm{Q}_{\mathrm{a}, \mathrm{u}}\right)$ for watersheds were obtained by RWQMN (see Appendix A). Discharge data from USGS monitoring stations of the surrounding Susquehanna River Basin were used to approximate a range of discharges from the average annual value. One set of USGS monitoring stations were selected based on their location as encompassing drainage areas of RWQMN stations, and another set were USGS stations in near proximity of nearly the same drainage area and stream order. USGS reports average daily values and an average annual discharge; the drainage-area ratio method for determining stream flow in ungaged watersheds (Emerson et al. 2005) was applied to determine if the USGS station was comparable to the RWQMN station. The best fit was based on the accuracy of the method reported by Emerson et al. (2005) for estimating the unmonitored watershed's drainage area and average annual discharge from the analysis of gaged drainage areas (Table 4). Percent error was calculated by the following equation:

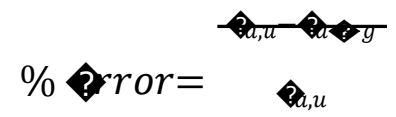

where $D_{a, u}$ is the drainage area of the ungaged watershed, provided by SRBC; $D_{a u-g}$ is the drainage area estimated by the Emerson et al. (2005) method.

USGS monitoring stations within the same stream network as the RWQMN station have most accurate for drainage areas on the scale of hundreds of square miles. For drainage areas less than $130 \mathrm{~km}^{2}\left(50 \mathrm{mi}^{2}\right)$, the use of smaller drainage areas nearby was consistently more accurate. Full results can be found in Appendix A. 
Table 4 Rate of error for the Emerson et al. (2005) method to estimate the drainage area and discharge of an ungaged watershed ( $D_{a, u}$ and $Q_{u}$, respectively), from data of a gaged drainage area $\left(D_{\text {ag }}\right)$ and average annual discharge $\left(Q_{g}\right)$.

\begin{tabular}{ccc|ccc|c}
\hline $\begin{array}{l}\text { RWQMN } \\
\text { watershed name }\end{array}$ & $\mathbf{D}_{\mathbf{a}, \mathbf{u}}\left(\mathbf{k m}^{\mathbf{2}}\right)$ & $\mathbf{Q}_{\mathbf{u}}(\mathbf{c m s})$ & $\begin{array}{l}\text { USGS } \\
\text { monitoring } \\
\text { station }\end{array}$ & $\mathbf{D}_{\mathbf{a g}}\left(\mathbf{k m}^{\mathbf{2}}\right)$ & $\mathbf{Q}_{\mathbf{g}}(\mathbf{c m s})$ & \% Error \\
\hline EB Wyalusing & 179 & 2.85 & 1533400 & 22,600 & 365 & $-9.00 \%$ \\
Mesohoppen & 134 & 2.15 & 1533400 & 22,600 & 365 & $-8.60 \%$ \\
Snake Creek & 117 & 2.12 & 1452500 & 117 & 1.75 & $-7.20 \%$ \\
Hammond Creek & 75.1 & 0.99 & 1603500 & 77.7 & 0.91 & $-15 \%$ \\
Sugar Run & 85.4 & 1.39 & 1569000 & 85.4 & 1.70 & $-26 \%$ \\
Sugar Creek & 145 & 1.98 & 1531325 & 243 & 3.11 & $-2.80 \%$ \\
Pine Creek & 997 & 15.6 & 1548500 & 1550 & 24.0 & $-15 \%$ \\
Little Muncy & 132 & 2.32 & 1473120 & 139 & 2.27 & $15 \%$ \\
$\quad$ Creek & 466 & 7.08 & 1549700 & 2430 & 40 & $-15 \%$ \\
Little Pine Creek & 4670
\end{tabular}

This method of comparison was rather versatile; all but one of the RWQMN watersheds (Little Muncy Creek) had a USGS monitoring station within its same stream network.

Average daily discharge rates were generalized with a histogram and data were fit to a gamma distribution. A gamma distribution is appropriate for modeling the annual variation of river discharge (Bedient and Huber 2001). The shape $(\mathrm{k})$ and the scale $(\Theta)$ of the gamma distribution for USGS daily average annual discharge (Table 5) were placed in Excel's inverse gamma distribution function, which estimated a random flow-rate for the USGS gaged watershed. This was then used to estimate a range of flows from the SRBC ungaged watersheds using equation 2.

$$
\hat{Q}=\frac{\boldsymbol{\Omega}_{a, u}}{\boldsymbol{\vartheta}_{, g}} Q_{g}(2)
$$

where $Q_{u}=$ average annual flow for ungaged watershed; $D_{a, u}=$ drainage area of ungaged watershed; $D_{a, g}=$ drainage area of gaged watershed; $Q_{g}=$ average annual flow for gaged watershed. 
Table 5 Results of the gamma distribution calculation from USGS gaged watersheds.

\begin{tabular}{|c|c|c|c|c|}
\hline USGS Station & $\begin{array}{l}\text { Range of Daily } \\
\text { Average Discharge } \\
\text { Data }\end{array}$ & Skew & Shape, k & Scale, $\Theta$ \\
\hline 01603500 & 1933 to 1982 & 0.90 & 2.0 & 16 \\
\hline 01569000 & 1938 to 1974 & 4.1 & 2.4 & 25 \\
\hline 01452500 & 2007 to 2015 & 5.1 & 6.5 & 8.8 \\
\hline 01473120 & 1966 to 1994 & 1.3 & 2.5 & 32 \\
\hline 01531325 & 2010 to 2015 & 5.8 & 0.12 & 870 \\
\hline 01533400 & 2007 to 2015 & 1.1 & 3.4 & 3,800 \\
\hline 01549700 & 1957 to 2014 & 1.1 & 3.5 & 400 \\
\hline 01548500 & 1918 to 2013 & 1.1 & 2.1 & 400 \\
\hline
\end{tabular}

Graphical results of the gamma distribution calculations can be found in Appendix A. The gamma distribution was found to be a better fit for data that had accumulated for more than five years.

\section{Calculating a range of peak concentrations for the case studies}

One hundred random flows were generated for the SRBC watersheds according to the gamma distribution of USGS gaged watersheds. The peak concentration is related to the time for the contaminant to travel from its source to the monitoring location. The velocity of the contaminant is determined by equation 3 .

$$
\hat{Q}=0.020+0.051\left(\hat{\theta}_{a}^{\prime}\right)^{0.821}\left(Q^{\prime} \quad\right)^{-0.465}(\underline{\theta})
$$

where, $V_{p}=$ velocity of peak concentration; $D^{\prime}{ }_{a}=$ adjusted drainage area; $Q^{\prime}{ }_{a}=$ adjusted annual flow; $D_{a}=$ drainage area of the monitored watershed.

The distance for the spill to travel was determined by a straight-line measurement from the API location to the monitoring station, irrespective of the actual path of streams. This length is an underestimation of the actual travel distance, streams seldom flow in a straight line. This would cause the predicted peak concentrations to be slightly overestimated, as the effects of longitudinal dispersion increase with greater distances travelled (Fischer et al.1979). 
The travel-time was determined by the distance the contaminant would have traveled and the velocity of the peak concentration, $\left(t_{p}=d /\left(V_{p}\right)\right)$. The travel time is a necessary variable for calculating peak concentration $\left(\mathrm{C}_{\mathrm{up}}\right)$ in equation 4 .

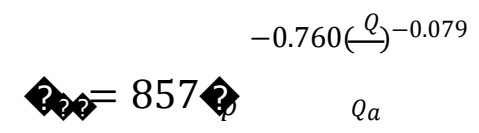

where, $T_{p}=$ travel time of peak concentration; $Q_{a}=$ mean annual river discharge; $Q=$ river flow at the section at the time of measurement (Jobson 1996).

The peak concentration gives a realistic magnitude to test with water quality monitoring devices. It incorporates dilution due to surface water dispersion during transport and the typical discharge rates of streams.

This information for each case study spill generated a range of peak contaminant concentrations (Table 6). The peak concentration results demonstrate the desired detectable limit for the SRBC RWQMN continuously monitoring systems. These concentrations were used in the laboratory experiments for instrument testing. 
Table 6 Ranges of peak concentration that would be measured at the RWQMN monitoring stations for the case study spills.

\begin{tabular}{|c|c|c|c|c|}
\hline $\begin{array}{l}\text { RWQMN } \\
\text { Watershed }\end{array}$ & Material Spilled & $\begin{array}{c}\text { Volume } \\
\text { (bbl.) }\end{array}$ & $\begin{array}{c}\text { Distance } \\
\text { Traveled } \\
\text { (km) }\end{array}$ & $\begin{array}{c}\text { Range of } \\
\text { Concentration } \\
(\text { ppm })\end{array}$ \\
\hline Mesohoppen & Production fluid (flow back) & 150 & 14 & $1.1-2.1$ \\
\hline Little Muncy Creek & Production fluid (flow back) & 130 & 7.4 & $0.99-3.07$ \\
\hline Hammond Creek & Production fluid & 50 & 9.9 & $0.85-1.87$ \\
\hline EB Wyalusing & Drilling mud (bentonite), cement & 104 & 18 & $0.53-1.1$ \\
\hline Snake Creek & Drilling Mud & 10 & 2.4 & $0.20-0.39$ \\
\hline EB Wyalusing & Drilling mud (freshwater) & 20 & 11 & $0.12-0.30$ \\
\hline EB Wyalusing & Production fluid & 20 & 13 & $0.11-0.26$ \\
\hline Sugar Creek & Production fluid & 20 & 7.0 & $0.07-0.60$ \\
\hline Little Pine Creek & Production fluid (brine) & 20 & 7.0 & $0.07-0.15$ \\
\hline Little Pine Creek & Diesel Fuel & 6.5 & 4.3 & $0.03-0.07$ \\
\hline EB Wyalusing & Diesel Fuel & 3.5 & 19 & $0.02-0.04$ \\
\hline Mesohoppen & Diesel Fuel & 2.3 & 12 & $0.02-0.04$ \\
\hline Mesohoppen & Production fluid & 3 & 14 & $0.018-0.049$ \\
\hline Pine Creek & Production fluid & 12 & 14 & $0.014-0.033$ \\
\hline Sugar Run & Production fluid (water) & 0.59 & 3.5 & $0.013-0.036$ \\
\hline Little Muncy Creek & Production fluid (flow back) & 1 & 7.9 & $0.007-0.022$ \\
\hline Mesohoppen & Production fluid (flow back) & 1 & 17 & $0.006-0.013$ \\
\hline Sugar Run & Corrosion Inhibitor & 0.47 & 11 & $0.006-0.013$ \\
\hline EB Wyalusing & $\begin{array}{c}\text { Mixture of drilling mud and } \\
\text { water }\end{array}$ & 0.88 & 13 & $0.005-0.011$ \\
\hline Sugar Creek & Drilling Mud & 0.59 & 5.9 & $0.002-0.020$ \\
\hline Little Pine Creek & Production fluid & 0.7 & 6.1 & $0.002-0.005$ \\
\hline Little Pine Creek & $\begin{array}{l}\text { Mixture of (drilling) mud, oil, } \\
\text { diesel fuel }\end{array}$ & 0.76 & 12 & $0.002-0.004$ \\
\hline
\end{tabular}

The concentration of a contaminant decreases logarithmically over a distance. The volume of a spill significantly affects its persistence as a high peak concentration. Figure 2 demonstrates the median peak concentration from the case studies. 


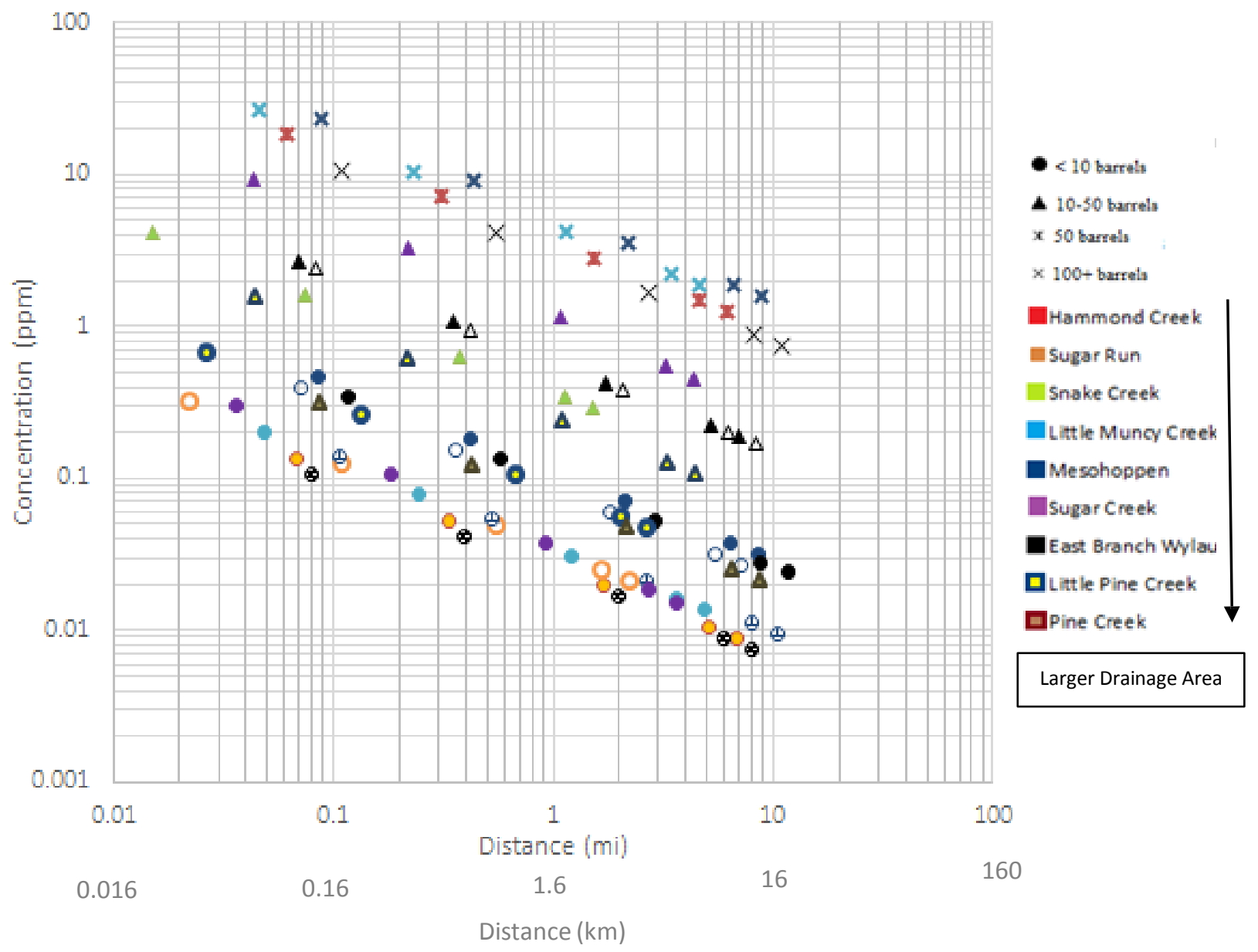

Figure 2 Median peak concentration for chemical spills as a function of distance travelled in the watershed.

The results were used as a guide for the concentrations to be measured in the laboratory experiments. Peak concentrations were calculated from less than $0.16 \mathrm{~km}$ (one tenth of a mile) to the maximum distance traveled in the case studies about $16 \mathrm{~km}$ (ten miles). It is possible for a peak concentration to range from parts per trillion after traveling $16 \mathrm{~km}$ to about $50 \mathrm{ppm}$ from traveling less than $0.16 \mathrm{~km}$. Fifty ppm was the target concentration to be observed in the laboratory studies. Contaminants spilled in larger volumes, such as drilling mud and produced water, could have peak concentrations of around $1 \mathrm{ppm}$ after traveling over $16 \mathrm{~km}$ in the watershed. 


\subsection{Procedure for laboratory experiments}

In the laboratory experiments, the contaminant was prepared in a dilute solution, and incrementally added to a pail containing deionized water. Sensors measuring common water quality parameters were submerged in the pail, and would measure the water quality. The experiments were repeated for three chemicals. The measurements were analyzed to determine whether there was a detectable signal from the increasing contaminant concentration.

\section{Apparatus}

Two water quality monitoring instruments, the Campbell Scientific (CS) CR-1000 datalogging system (Logan, UT) and the AquaTROLL (AT) 200 (Ft. Collins, CO) were submerged in a bench-scale laboratory apparatus. The apparatus consisted of a $3.78 \mathrm{~L}$ (1 gallon) plastic container, $19 \mathrm{~cm}$ in diameter and $18 \mathrm{~cm}$ deep. Initially the pail contained $1.2 \mathrm{~L}$ of deionized water, the minimum water depth to submerge both instruments was $3.5 \mathrm{~cm}$. The instruments were suspended with a mounting rod (Figures 3 and 4).

Diluted chemicals were added to the initial set up at standard intervals of 5 minutes, while the solution was constantly stirred (Figure 3c). Temperature was not controlled but was recorded with both submerged sensors throughout the study. All sensors were calibrated according to manufacturer standards. 


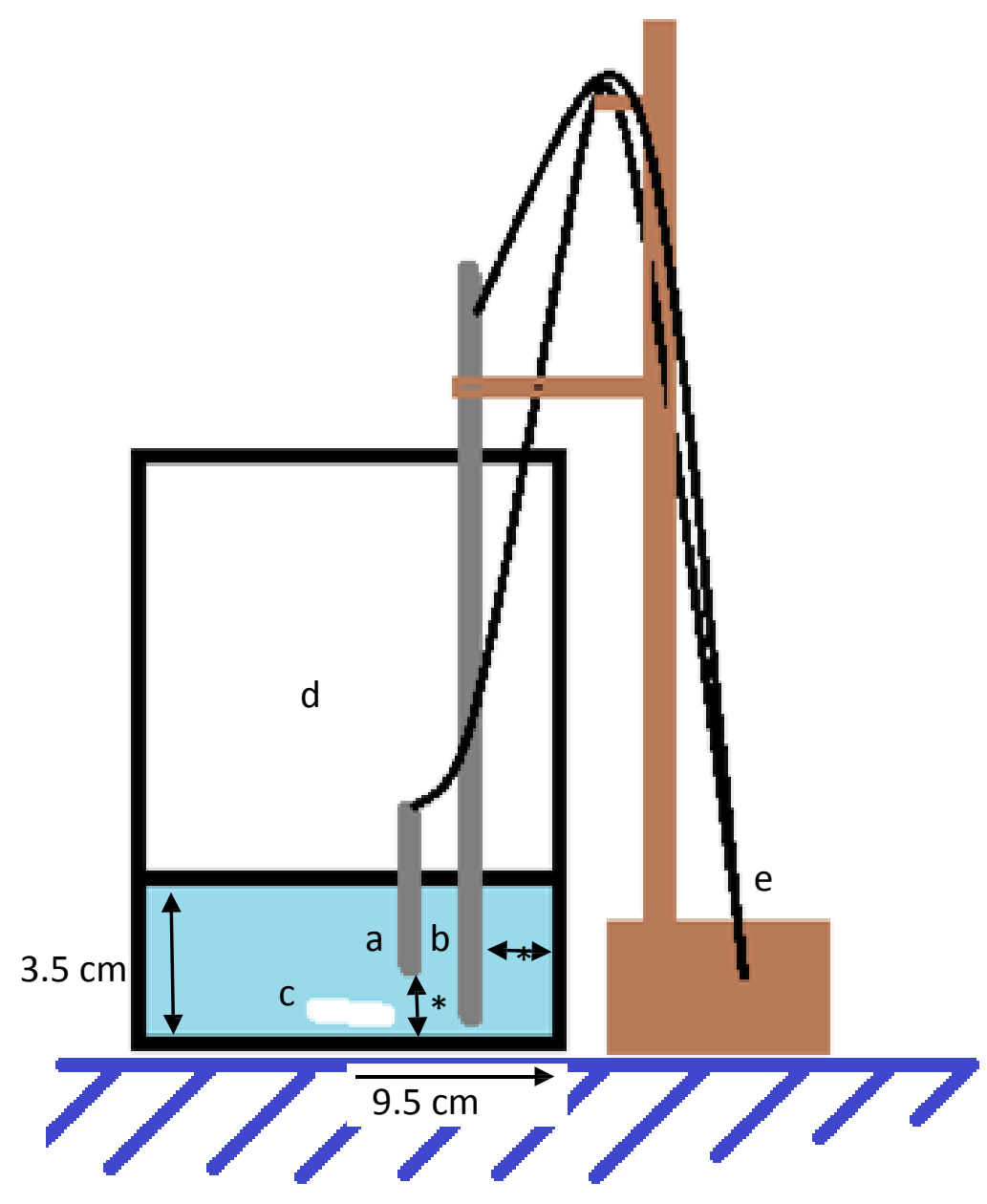

Figure 3 Initial laboratory experiment apparatus, a) the CR-1000 probes; b) the AquaTROLL; c) deionized water and a stir bar; d) the 3.78L pail; and e) instrument cords to computer communication. *The placement of the sensors were near the pail walls and near the bottom of the pail. 


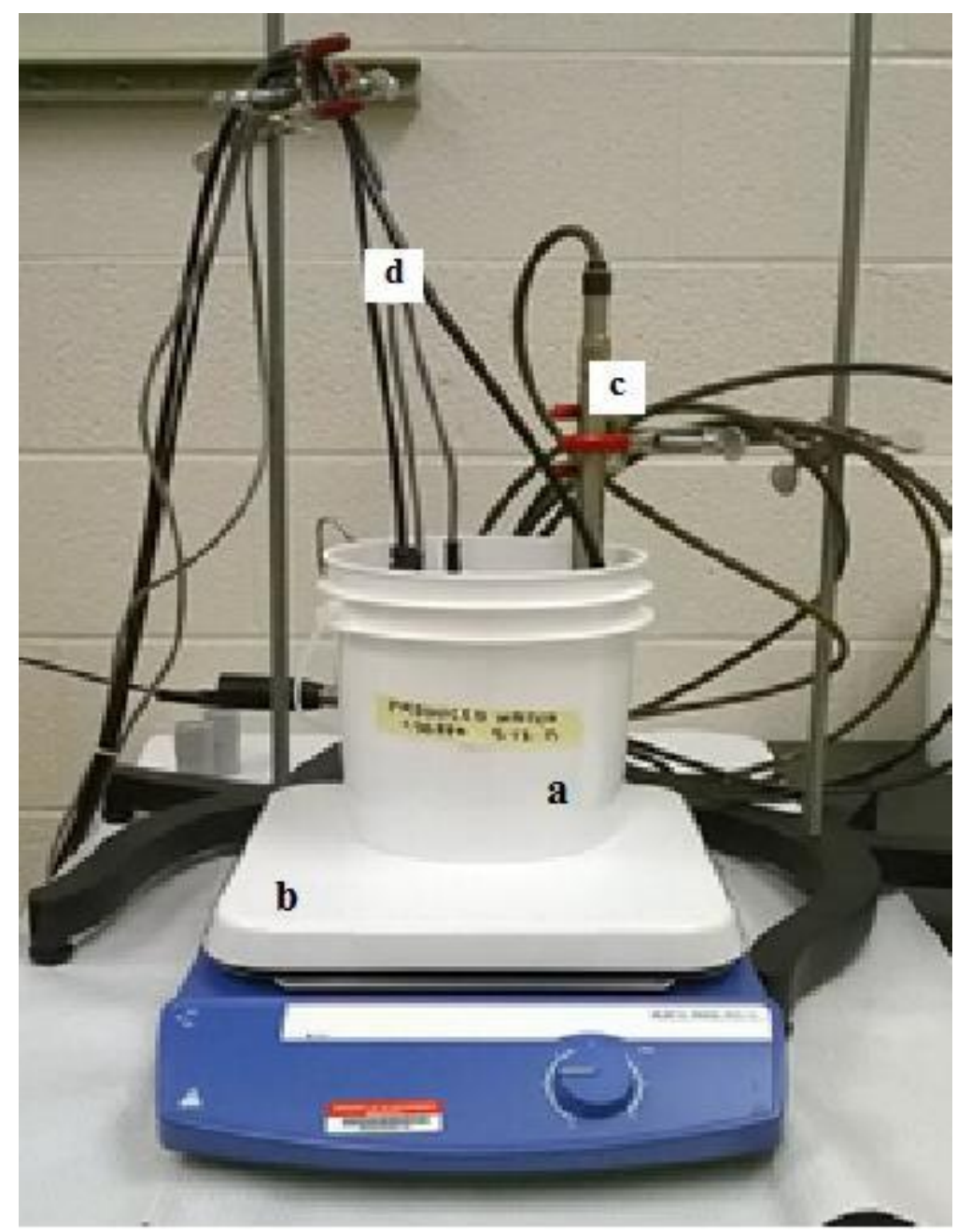

Figure 4 A photograph of the laboratory apparatus. a) The pail containing deionized water; b) the magnetic stirrer; c) the AquaTROLL 200; d) the CS-CR-1000 probes for $\mathrm{pH}$, dissolved oxygen, ORP and temperature/conductivity.

The CS-CR1000 data-logger had four attachments: the CS-511 dissolved oxygen sensor, the CSIM-11 pH sensor, the CS A547 temperature and conductivity sensor, and the CSIMM-11 oxidation reduction potential (ORP) sensor. The dissolved oxygen and conductivity sensors were calibrated for operating temperature twice during the two-week duration of experiments. The calibration fluid used was $1,280 \mu \mathrm{S} / \mathrm{cm}$ standard. $\mathrm{pH}$ and ORP sensors were calibrated by standard 4 and 7 buffers and Zobell solution once a week. This data-logger was set to scan every 15 seconds and to output the measurement. 
An AquaTROLL 200 measured temperature and conductivity. The AT was calibrated with $1,280 \mu \mathrm{S} / \mathrm{cm}$ standard. The AT was set to record measurements every 1 minute, which is the minimum frequency available. The specifications for both instruments can be found in Table 7 .

Table 7 Laboratory tested instrument ranges of operation and accuracy.

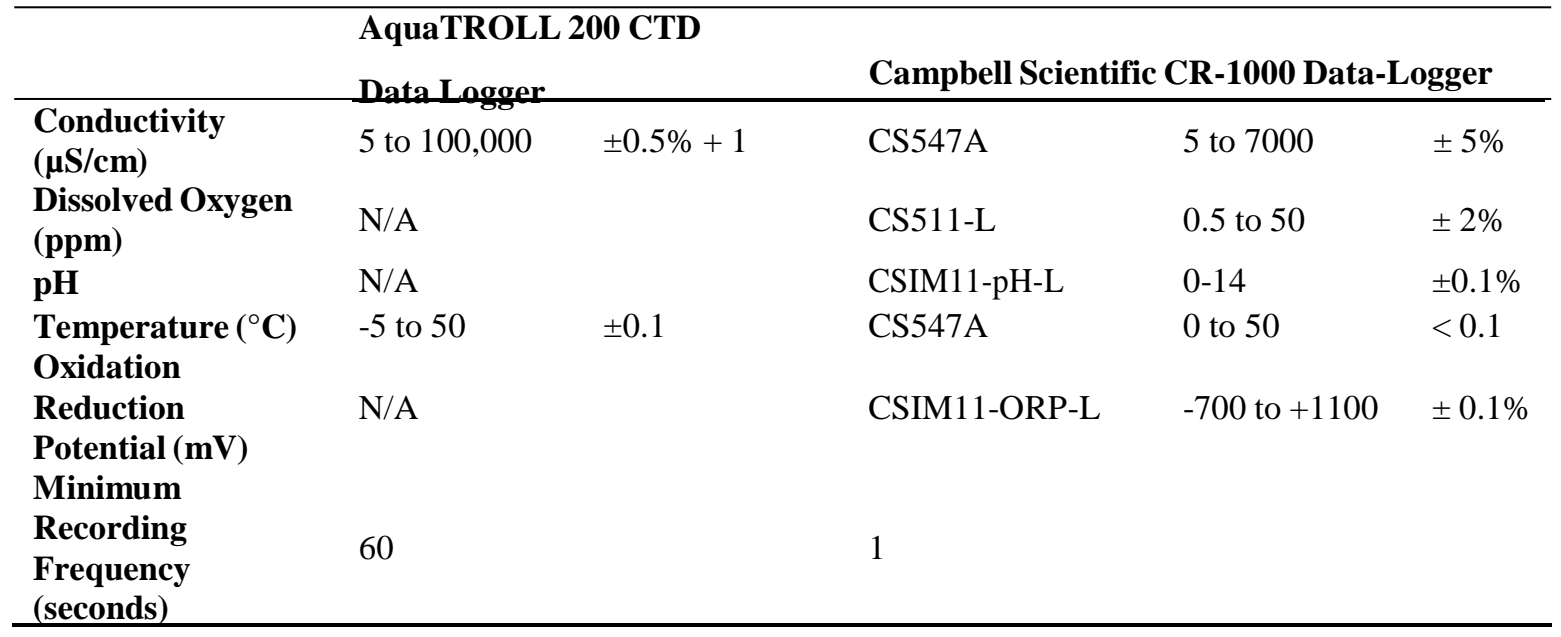

\section{Chemicals}

The stock chemicals were prepared at full concentration and then diluted to smaller concentrations using deionized water. The chemicals tested were 1,000 ppm ethylene glycol, $10,000 \mathrm{~mL} / \mathrm{m}^{3}$ drilling mud, and $10,000 \mathrm{~mL} / \mathrm{m}^{3}$ produced water from a well in Greene County, Pennsylvania. For ease of description in results, the $\mathrm{mL} / \mathrm{m}^{3}$ units will be referred to as ppm.

The produced water came from wells that were part of an initiative of the National Energy Technology Lab to investigate the impacts of hydraulic fracturing on drinking water availability and quality. The wells had been drilled in March 2012 into the Marcellus Shale (Hammack et al. 2013). The produced water was collected in the summer of 2014. The source container for the produced water was a white $15 \mathrm{~L}$ bucket that appeared to have either sediment settlement or orange-colored corrosion on its inner-sides. 
The drilling mud was composed based on published values for water-based drilling mud (Caenn et al. 2011). Its composition is for every $4 \mathrm{~L}$ of water, $20 \mathrm{~g}$ of xanthan gum, $56 \mathrm{~g}$ of bentonite clay, $40 \mathrm{~g}$ of carboxymethyl cellulose, and $1.8 \mathrm{~g}$ of Barite. Guar gum was used instead of xanthan gum, an equivalent thickening constituent.

\section{Experiment Procedure}

Deionized water was used to submerge the sensors. The initial volume varied from $1.2 \mathrm{~L}$ to $1.4 \mathrm{~L}$ and was recorded for each trial (Table 4). The sensors were turned on and allowed to stabilize for up to 15 minutes. For each chemical, in separate trials, the concentration was increased at $1 \mathrm{ppm}$ increments every five minutes. The five minute time-step was based on the possibility that the apparatus would heat up during operation, which could affect the sensor readings. Once the concentration reached $20 \mathrm{ppm}$, the volume of injection was increased to 5 ppm increments. This was continued until the target concentration reached 40 to $50 \mathrm{ppm}$. This target concentration is based on the estimated peak concentrations from the case studies. Four repetitions for each contaminant were conducted (12 trials in total). The immediate time stamp of the data logger, along with all of its water quality parameter measurements was recorded. After the target concentration was reached, the data was processed to determine the average water quality parameter value every $5 \mathrm{~min}$. The standard deviation was also calculated.

Table 8 the initial volume ( $\mathrm{L})$ and the total added volume of contaminant $(\mathrm{mL})$ for the laboratory trials.

\begin{tabular}{llll}
\hline Chemical Type, & Ethylene Glycol, & $\begin{array}{l}\text { Produced Water, } \\
\mathbf{1 0 , 0 0 0} \mathbf{~ p p m}\end{array}$ & $\begin{array}{l}\text { Drilling mud, } \\
\mathbf{1 0 , 0 0 0} \mathbf{~ p p m}\end{array}$ \\
Stock Concentration & $\mathbf{1 , 0 0 0} \mathbf{~ p p m}$ & $1.2(6)$ & $1.5(7.5)$ \\
Trial 1 & $1.3(65)$ & $1.2(6)$ & $1.3(6.5)$ \\
Trial 2 & $1.3(65)$ & $1.2(6)$ & $1.3(9.6)$ \\
Trial 3 & $1.2(60)$ & $1.2(6)$ & $\underline{1.3(6.5)}$ \\
Trial 4 & $1.3(65)$ & $\underline{y}$
\end{tabular}




\section{Data Analysis}

A paired t-test was conducted between experimental trials to determine if the measurements were consistent. A paired t-test was also conducted between the two instruments to determine if their measurements across the instruments are the same. An $\alpha$ of 0.05 was assumed for all tests. From these results, further correlation analysis was conducted in order to determine if certain water quality parameters correlate with increasing chemical concentration. A strong correlation was defined as 0.85 to 1.0 , a moderate correlation was defined as 0.25 to 0.84 , and weak correlation was defined as less than 0.24 .

\subsection{Results}

\subsubsection{Drilling Mud}

Specific conductivity, $\mathrm{pH}$, oxidation reduction potential (ORP) and dissolved oxygen (DO) were significantly different among the trials for the Campbell Scientific (CS) probes (Table 9). The AquaTROLL (AT) showed significant differences across the trials in specific conductivity and temperature. The temperature for Trial 2 and 3 for the CS probe were similar, and Trial 2 and 4 for the AT were similar. 
Table 9 p-value results of the paired t-test comparing the trials of the drilling mud tests.

\begin{tabular}{|c|c|c|c|c|c|c|}
\hline & \multicolumn{3}{|c|}{ Campbell Scientific } & \multicolumn{3}{|c|}{ AquaTROLL } \\
\hline $\begin{array}{l}\text { Temperature } \\
\text { Trial } 2\end{array}$ & $\begin{array}{c}\text { Trial 1 } \\
<0.0001\end{array}$ & Trial 2 & Trial 3 & $\begin{array}{c}\text { Trial 1 } \\
<0.0001\end{array}$ & Trial 2 & Trial 3 \\
\hline Trial 3 & $<0.0001$ & $<0.0001$ & & $<0.0001$ & $<0.0001$ & \\
\hline Trial 4 & $<0.0001$ & 0.25 & $<0.0001$ & $<0.0001$ & 0.079 & $<0.0001$ \\
\hline Specific & & & & & & \\
\hline $\begin{array}{l}\text { Conductivity } \\
\text { Trial } 2\end{array}$ & $\begin{array}{c}\text { Trial 1 } \\
<0.0001\end{array}$ & Trial 2 & Trial 3 & $\begin{array}{c}\text { Trial 1 } \\
<0.0001\end{array}$ & Trial 2 & Trial 3 \\
\hline Trial 3 & $<0.0001$ & $<0.0001$ & & $<0.0001$ & $<0.0001$ & \\
\hline Trial 4 & $<0.0001$ & $<0.0001$ & $<0.0001$ & $<0.0001$ & $<0.0001$ & $<0.0001$ \\
\hline pH & Trial 1 & Trial 2 & Trial 3 & & & \\
\hline Trial 2 & 0.00026 & & & & & \\
\hline Trial 3 & $<0.0001$ & $<0.0001$ & & & & \\
\hline Trial 4 & $<0.0001$ & $<0.0001$ & $<0.0001$ & & & \\
\hline ORP & Trial 1 & Trial 2 & Trial 3 & & & \\
\hline Trial 2 & $<0.0001$ & & & & & \\
\hline Trial 3 & $<0.0001$ & $<0.0001$ & & & & \\
\hline Trial 4 & $<0.0001$ & $<0.0001$ & $<0.0001$ & & & \\
\hline DO & Trial 1 & Trial 2 & Trial 3 & & & \\
\hline Trial 2 & $<0.0001$ & & & & & \\
\hline Trial 3 & 0.0013 & $<0.0001$ & & & & \\
\hline Trial 4 & $<0.0001$ & $<0.0001$ & $<0.0001$ & & & \\
\hline
\end{tabular}

The correlation tests (Table 10) showed that both CS and AT responded similarly in temperature and specific conductivity, with strong positive correlations. For the CS, $\mathrm{pH}$ results showed moderate to strong correlations in both directions: three negative correlations and three positive correlations; where Trial 4 had negative correlation with the other three trials. Trial 4 had a lower starting $\mathrm{pH}$ than the other three, so over the course of the test the $\mathrm{pH}$ increased. Oxidation reduction potential showed moderate to strong correlations in both directions as well, but with four negative correlations and two positive correlations: Trial 3 and 4 had a moderately positive correlation, and Trial 1 and 2 had a strong positive correlation, the rest of the comparisons had a moderate to strong negative correlation. The oxidation reduction potential had most change at concentrations lower than $10 \mathrm{ppm}$, but after this concentration all trials converged with exception to trial 1. All trials had a slight decreasing trend. Dissolved oxygen showed weak negative correlations in three comparisons, and moderate to strong positive 
correlations in three comparisons. Again, the first part of the trial at about $5 \mathrm{ppm}$ did not have consistent response, but after 5 ppm the dissolved oxygen generally decreased.

Table 10 correlation coefficients comparing the trials of the drilling mud trials.

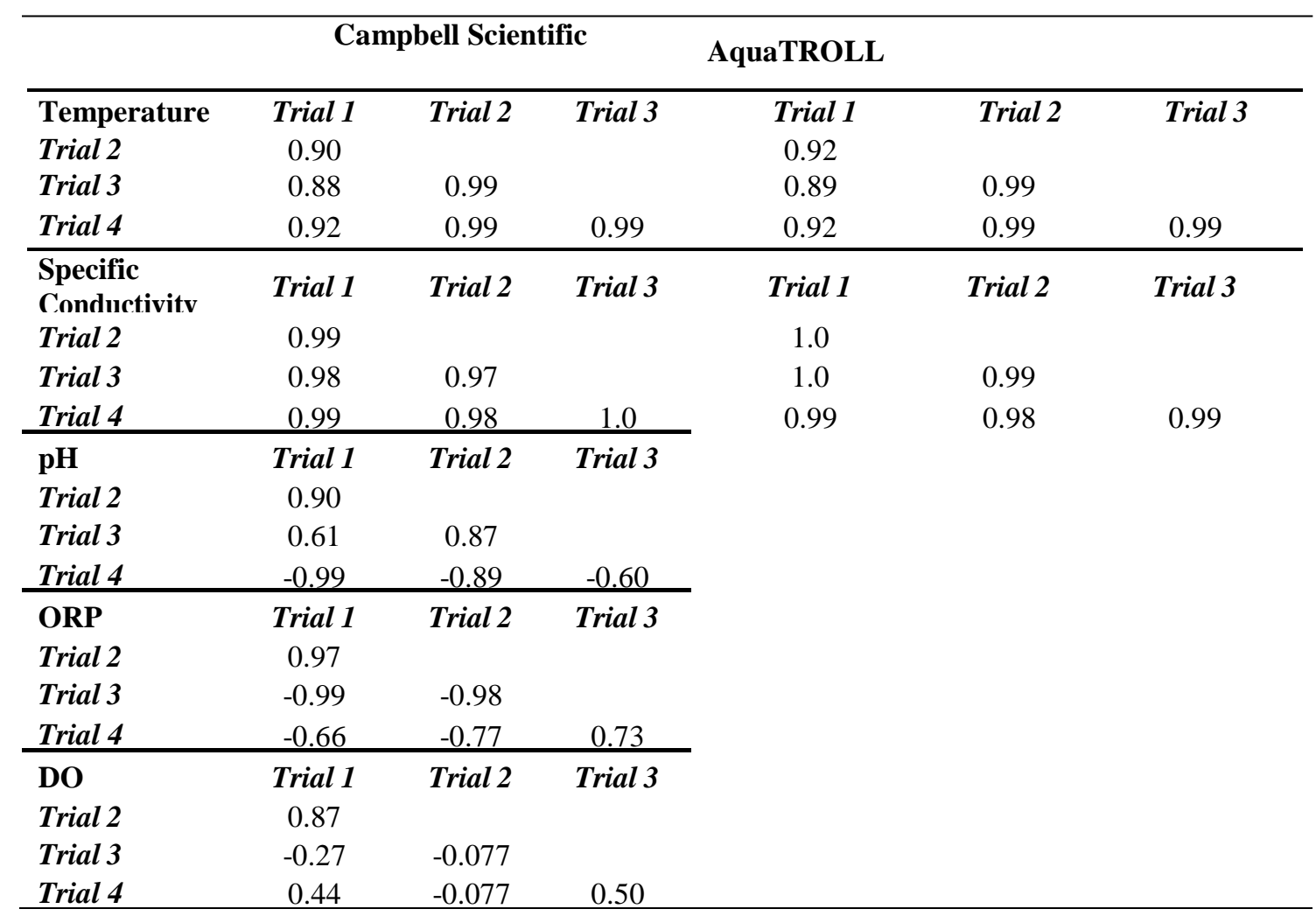

\section{Drilling mud impact on water quality parameters}

The drilling mud affected specific conductivity, dissolved oxygen and $\mathrm{pH}$. The specific conductivity increased at a rate of 0.1 to $0.2 \mu \mathrm{S} / \mathrm{cm}$ per ppm increase in concentration. Dissolved oxygen decreased by $0.2 \mathrm{ppm} / 50 \mathrm{ppm}$ drilling mud. $\mathrm{pH}$ had a tendency to converge at 6.3 , even from Trial 1 which had a starting $\mathrm{pH}$ of 8 . ORP had a tendency to converge at $-200 \mathrm{mV}$, except from Trial 1 which had an initial reading of $1,300 \mathrm{mV}$ that decreased exponentially to $600 \mathrm{mV}$. Temperature increased throughout the trials, probably due to the apparatus. The temperature throughout Trials 2, 3, and 4 increased at a rate of $0.018{ }^{\circ} \mathrm{C} / \mathrm{min}$, Trial 1 increased at a rate of $0.003^{\circ} \mathrm{C} / \mathrm{min}$. The measurements from the Campbell Scientific probes are shown in Figure 5 . 

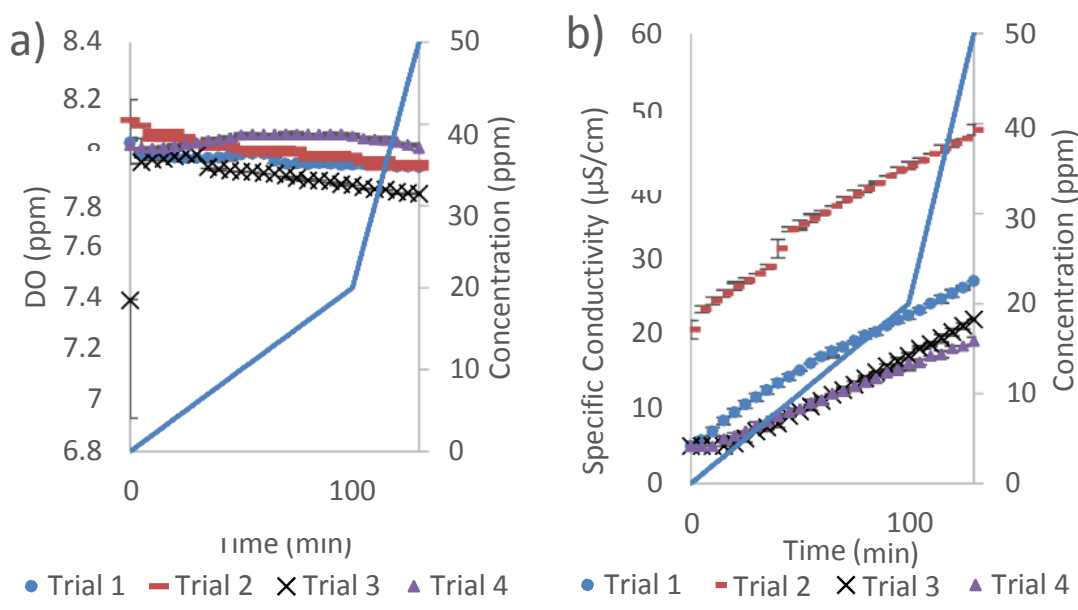

c)
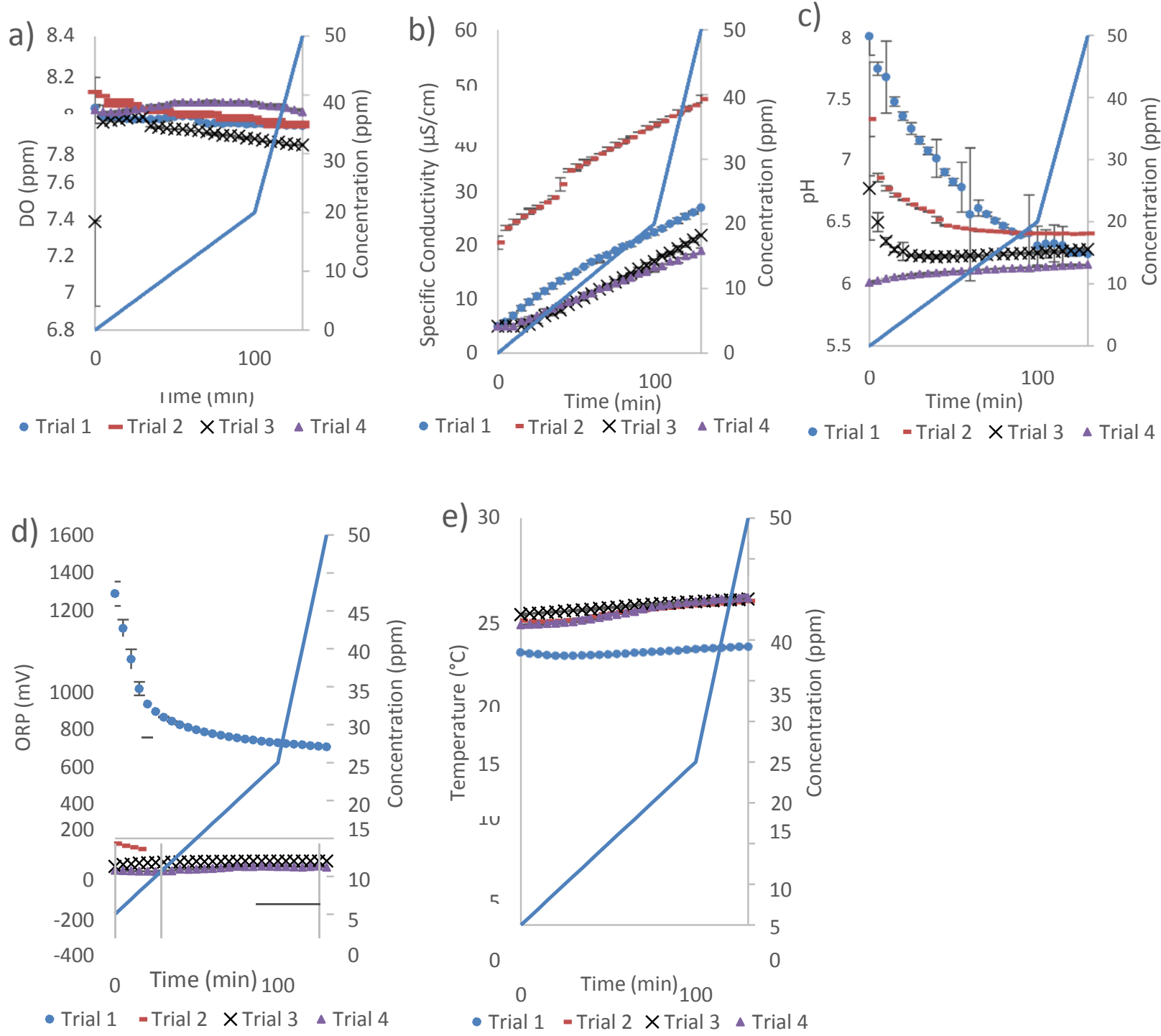

Figure 5 CS measurements from drilling mud experiments. a) dissolved oxygen, b) specific conductivity, c) pH, d) oxidation reduction potential, and e) temperature over time. Concentration is plotted against time with a solid line.

The AquaTROLL results are shown in Figure 6. The AT was able to detect the change in conductivity below $5 \mu \mathrm{S} / \mathrm{cm}$, which is below the range for the CS; this is observable in lower concentrations of drilling mud (see Trial 3 of Figure $6 \mathrm{~b}$ ). The phase shift of specific conductivity in drilling mud, Trial 2, was detected with both instruments. 

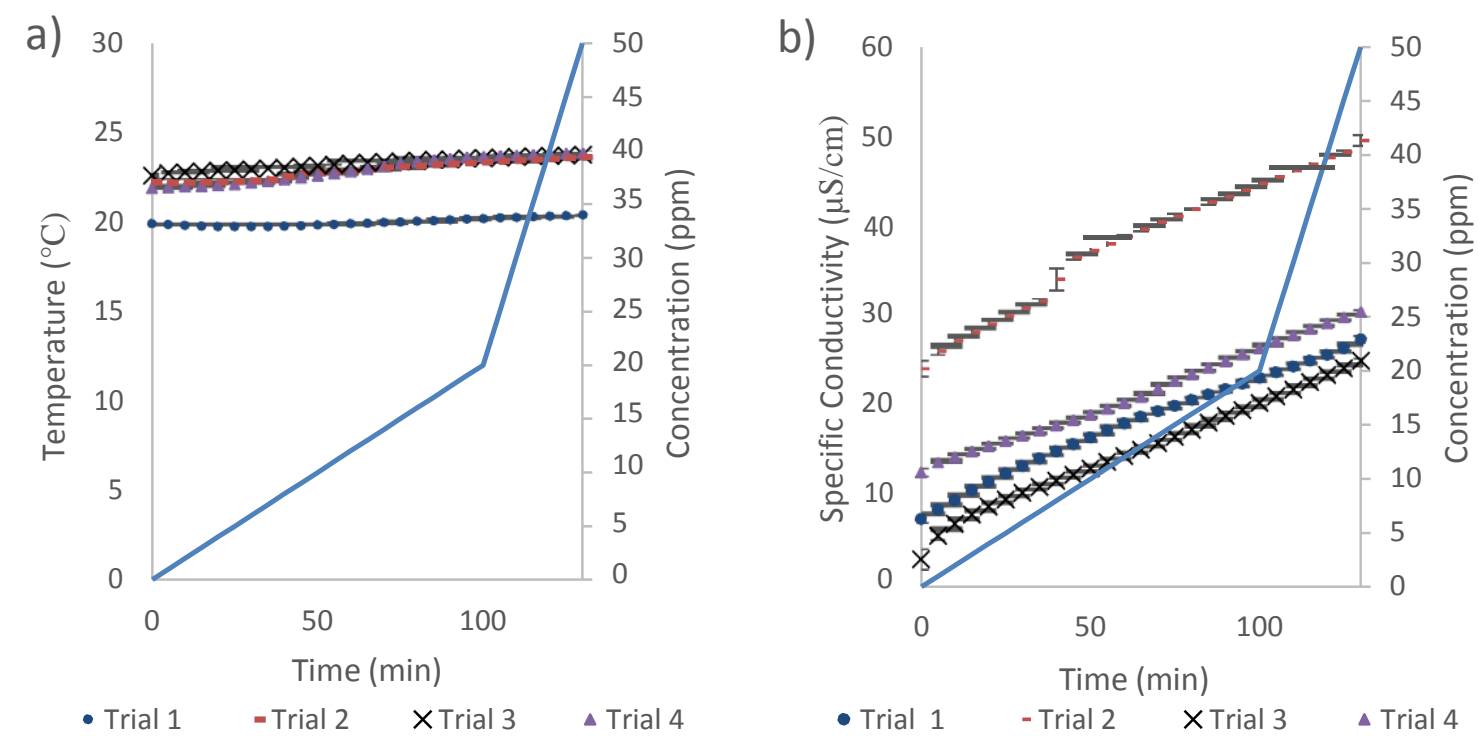

Figure 6 AT measurements from the drilling mud experiments. a) Temperature, b) specific conductivity over time. Concentration is plotted against time with a solid line.

\subsubsection{Produced Water}

In the four trials of the produced water, two (2 and 3 ) were conducted dissimilarly to one another, due to researcher's error: Trial 2 reached the same target concentration of $50 \mathrm{ppm}$, but had six injection volumes after $17 \mathrm{ppm}$ instead of nine like the other trials. Trial 3 had injection volumes equivalent to $10 \mathrm{ppm}$ instead of $5 \mathrm{ppm}$ once the concentration reached $20 \mathrm{ppm}$ in the pail. The paired t-test observations were conducted by organizing the data so that the statistical method would be applied only to the water quality parameters at identical concentrations.

The paired t-tests for the produced water trials generally failed, with exceptions in temperature (Trial 1 and 3 with the CS probe; Trial 2 and 4 with the AT) and specific conductivity (Trial 1 vs. 2 and Trial 1 vs. 3 with the CS probe; Trial 1 vs. 2 and Trial 1 vs. 3 with the AT) (Table 11). Another exception to the paired t-test failure was the comparison between Trial 3 and 4 in $\mathrm{pH}$. The CS and AT simultaneously demonstrated insignificant, but measureable, similarity in other trials. These results from the paired t-tests indicate that the trials were 
significantly different. This demonstrates that for a particular concentration the water quality measurement may not be the same.

Table 11 p-values for the paired t-test comparing the trials of the produced water.

\begin{tabular}{|c|c|c|c|c|c|c|}
\hline \multicolumn{4}{|c|}{ Campbell Scientific } & \multicolumn{3}{|c|}{ AquaTROLL } \\
\hline Temperature & Trial 1 & Trial 2 & Trial 3 & Trial 1 & Trial 2 & Trial 3 \\
\hline Trial 2 & $<0.0001$ & & & $<0.0001$ & & \\
\hline Trial 3 & 0.10 & $<0.0001$ & & 0.00014 & $<0.0001$ & \\
\hline Trial 4 & $<0.0001$ & 0.048 & $<0.0001$ & $<0.0001$ & 0.30 & $<0.0001$ \\
\hline $\begin{array}{l}\text { Specific } \\
\text { Conductivity }\end{array}$ & Trial 1 & Trial 2 & Trial 3 & Trial 1 & Trial 2 & Trial 3 \\
\hline Trial 2 & 0.19 & & & 0.21 & & \\
\hline Trial 3 & 0.067 & 0.0002 & & 0.11 & 0.0010 & \\
\hline Trial 4 & $<0.0001$ & 0.017 & 0.00090 & $<0.0001$ & 0.0084 & 0.0020 \\
\hline pH & Trial 1 & Trial 2 & Trial 3 & & & \\
\hline Trial 2 & $<0.0001$ & & & & & \\
\hline Trial 3 & $<0.0001$ & 0.0054 & & & & \\
\hline Trial 4 & $<0.0001$ & $<0.0001$ & 0.48 & & & \\
\hline ORP & Trial 1 & Trial 2 & Trial 3 & & & \\
\hline Trial 2 & $<0.0001$ & & & & & \\
\hline Trial 3 & $<0.0001$ & 0.020 & & & & \\
\hline Trial 4 & $<0.0001$ & $\leq 0.0001$ & $<0.0001$ & & & \\
\hline DO & Trial 1 & Trial 2 & Trial 3 & & & \\
\hline Trial 2 & $<0.0001$ & & & & & \\
\hline Trial 3 & 0.0021 & $<0.0001$ & & & & \\
\hline Trial 4 & $<0.0001$ & $<0.0001$ & $<0.0001$ & & & \\
\hline
\end{tabular}

Correlation coefficients for the produced water experiments are shown in Table 12. The temperature correlation for the CS and AT had consistently moderate to strong positive correlations, the exception being one negative comparison between Trial 1 and 3 for the CS probe. This trend was attributed to the apparatus. The specific conductivity had a consistently strong correlation in all comparisons, the least being $98 \%$ correlated. $\mathrm{pH}$ had consistently strong positive correlations in all comparisons. For these two parameters, it is possible to observe a consistent response to increasing concentration Oxidation reduction potential showed moderate positive correlation in three of the comparisons. The exceptions were associated with the fourth trial where it was weakly correlated in both negative and positive directions, and one strong 
correlation to Trial 2 . The correlation is attributed to a similar water quality response in all trials within the first $20 \mathrm{ppm}$ of the trial. The shape of the response curve is unique to this contaminant (refer to Figure 7d). After 20 ppm the shape of the response curves diverge. The dissolved oxygen showed mixed positive and negative strong correlations in the comparisons between Trials 2, 3, and 4; Trial 1 demonstrated weak positive correlations to the other three trials. It does not appear dissolved oxygen had a consistent response due to the increasing concentration of drilling mud.

Table 12 Correlation coefficients for the water quality parameters across the four produced water trials.

\begin{tabular}{|c|c|c|c|c|c|c|}
\hline \multirow[b]{2}{*}{ Temperature } & \multicolumn{3}{|c|}{ Campbell Scientific } & \multicolumn{3}{|c|}{ AquaTrolL } \\
\hline & Trial 1 & Trial 2 & Trial 3 & Trial 1 & Trial 2 & Trial 3 \\
\hline Trial 2 & 0.97 & & & 0.96 & & \\
\hline Trial 3 & -0.26 & 0.94 & & 0.85 & 0.94 & \\
\hline Trial 4 & 0.98 & 0.93 & 0.81 & 0.97 & 0.92 & 0.77 \\
\hline $\begin{array}{l}\text { Specific } \\
\text { Conductivity }\end{array}$ & Trial 1 & Trial 2 & Trial 3 & Trial 1 & Trial 2 & Trial 3 \\
\hline Trial 2 & 0.98 & & & 0.98 & & \\
\hline Trial 3 & 0.98 & 1.0 & & 0.98 & 1.0 & \\
\hline Trial 4 & 1.0 & 0.98 & 0.98 & 1.0 & 0.98 & 0.98 \\
\hline $\begin{array}{l}\text { pH } \\
\text { Trial } 2\end{array}$ & $\begin{array}{c}\text { Trial 1 } \\
0.92\end{array}$ & Trial 2 & Trial 3 & & & \\
\hline Trial 3 & 0.96 & 0.93 & & & & \\
\hline Trial 4 & 0.89 & 0.96 & 0.98 & & & \\
\hline ORP & Trial 1 & Trial 2 & Trial 3 & & & \\
\hline Trial 2 & 0.60 & & & & & \\
\hline Trial 3 & 0.44 & 0.053 & & & & \\
\hline Trial 4 & $<0.0001$ & 0.90 & -0.16 & & & \\
\hline DO & Trial 1 & Trial 2 & Trial 3 & & & \\
\hline Trial 2 & 0.31 & & & & & \\
\hline Trial 3 & 0.39 & 0.98 & & & & \\
\hline Trial 4 & 0.013 & -0.87 & -0.85 & & & \\
\hline
\end{tabular}

\section{Produced water impact on water quality parameters}

The different concentrations during the trial progression are evident in the specific conductivity measurements in Figure $7 b$. For all four trials, the specific conductivity increased at a rate of 1.7 to $2.4 \mu \mathrm{S} / \mathrm{cm}$ per $1 \mathrm{ppm}$ of produced water. Produced water contains ions dissolved 
from deep underground formations, from which it is released during oil and gas activities. Specific conductivity is a positive indicator for the presence of these dissolved ions. The oxidation reduction potential would increase by about $20 \mathrm{mV}$ in the first 35 minutes of the trial, and results will diverge either by increasing or decreasing oxidation reduction potential. The increasing trials would have a magnitude of $10 \mathrm{mV}$ after the first 35 minutes, decreasing trials would have a magnitude of about $5 \mathrm{mV}$. The phase shift in Trial 4 may have to do with an offset from either the instrument calibration or the instruments' sensitivity to temperature. The shape of the ORP signal, due to increasing concentration of produced water, is similar for all trials, irrespective of the starting oxidation reduction potential condition. The dissolved oxygen parameter did not react consistently in the trials. Two trials showed a decrease by about 0.15 to $0.20 \mathrm{ppm}$ dissolved oxygen per $50 \mathrm{ppm}$ of produced water, while the two other trials (Trial 1 and 4) had a parabolic trend. The fourth trial had increasing by $0.17 \mathrm{ppm}$ dissolved oxygen before trending downward to a net change of $0.9 \mathrm{ppm}$ at $50 \mathrm{ppm}$ produced water. The first Trial showed an increase by $0.01 \mathrm{ppm}$ halfway through the trial, and decreased for net loss of $0.07 \mathrm{ppm}$ over the course of the entire trial. Generally, the $\mathrm{pH}$ decreased at a rate from the range of 0.004 to 1.1 units/min and the measurements converged at about 6.5 at the end of the four 130 minute trials. It appears that produced water has a controlling force over the $\mathrm{pH}$. The water quality parameter results for the CS probes are found in Figure 7. 

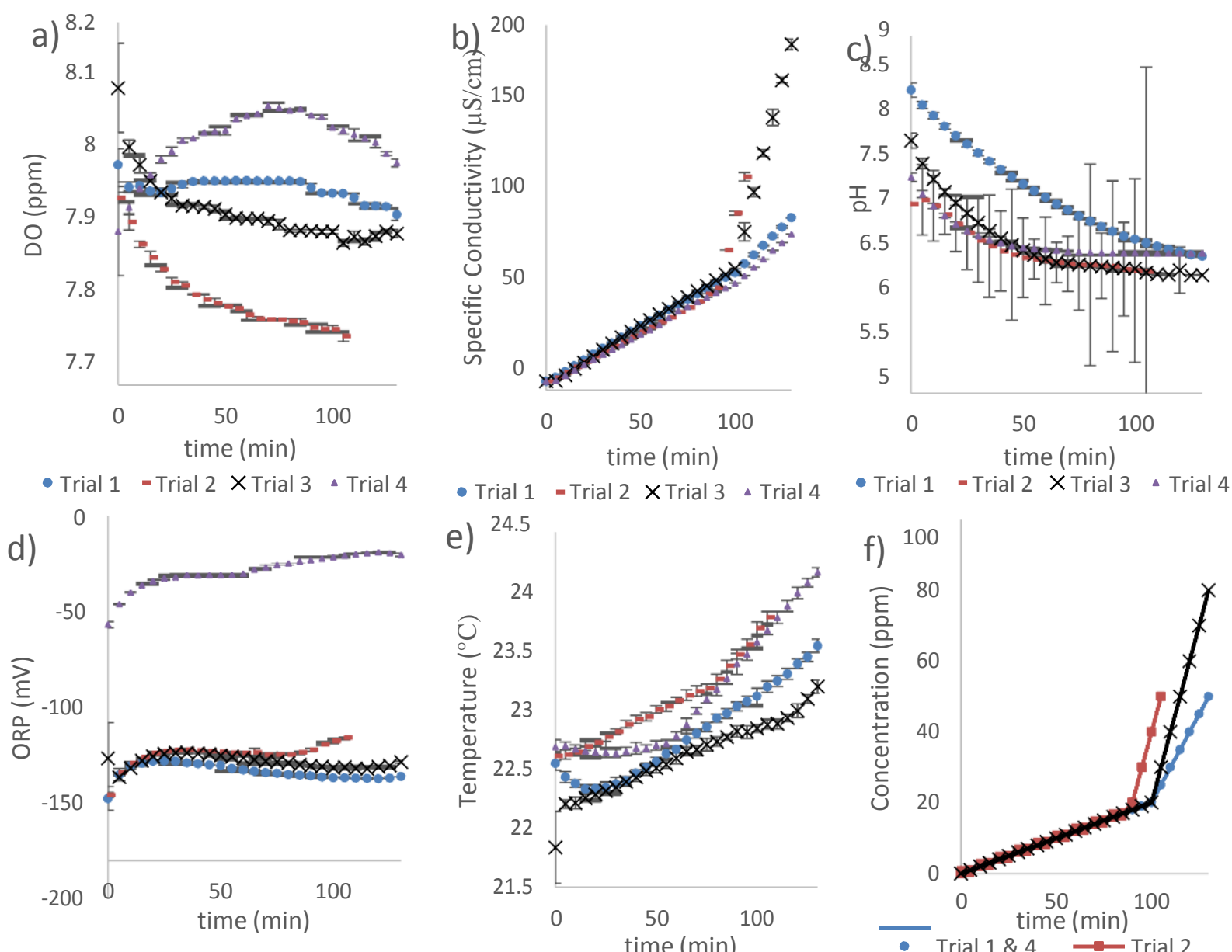

- Trial 1 -Trial $2 \times$ Trial $3 \Delta$ Trial 4
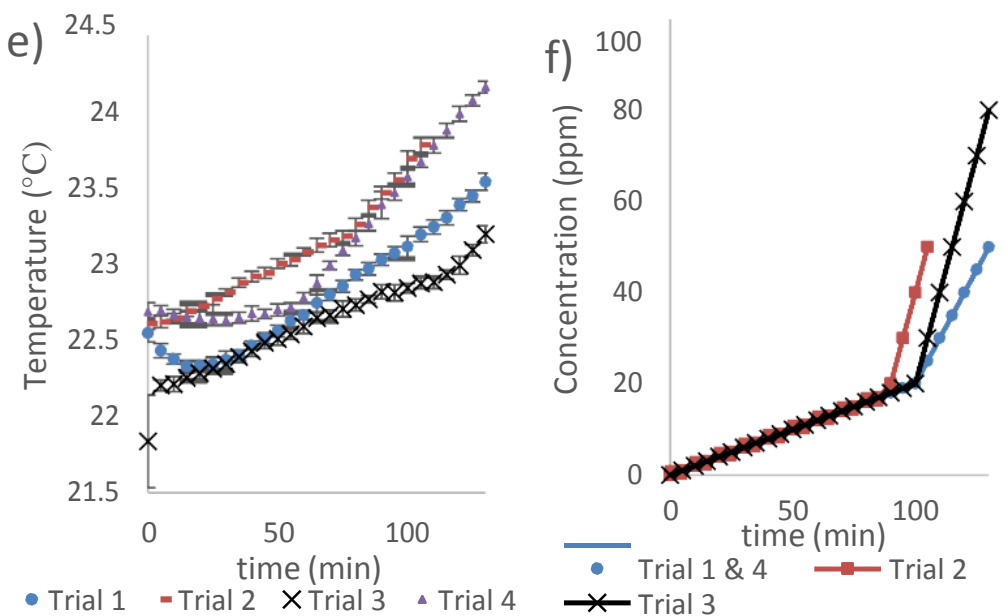

Figure 7 CS measurements from produced water experiments over time: a) dissolved oxygen, b) specific conductivity, c) pH, d) oxidation reduction potential, e) temperature, f) concentration for the trials.

The results for the AT measurements are shown in Figure 8. The response in these parameters are similar to those of the CS conductivity and temperature probes. 

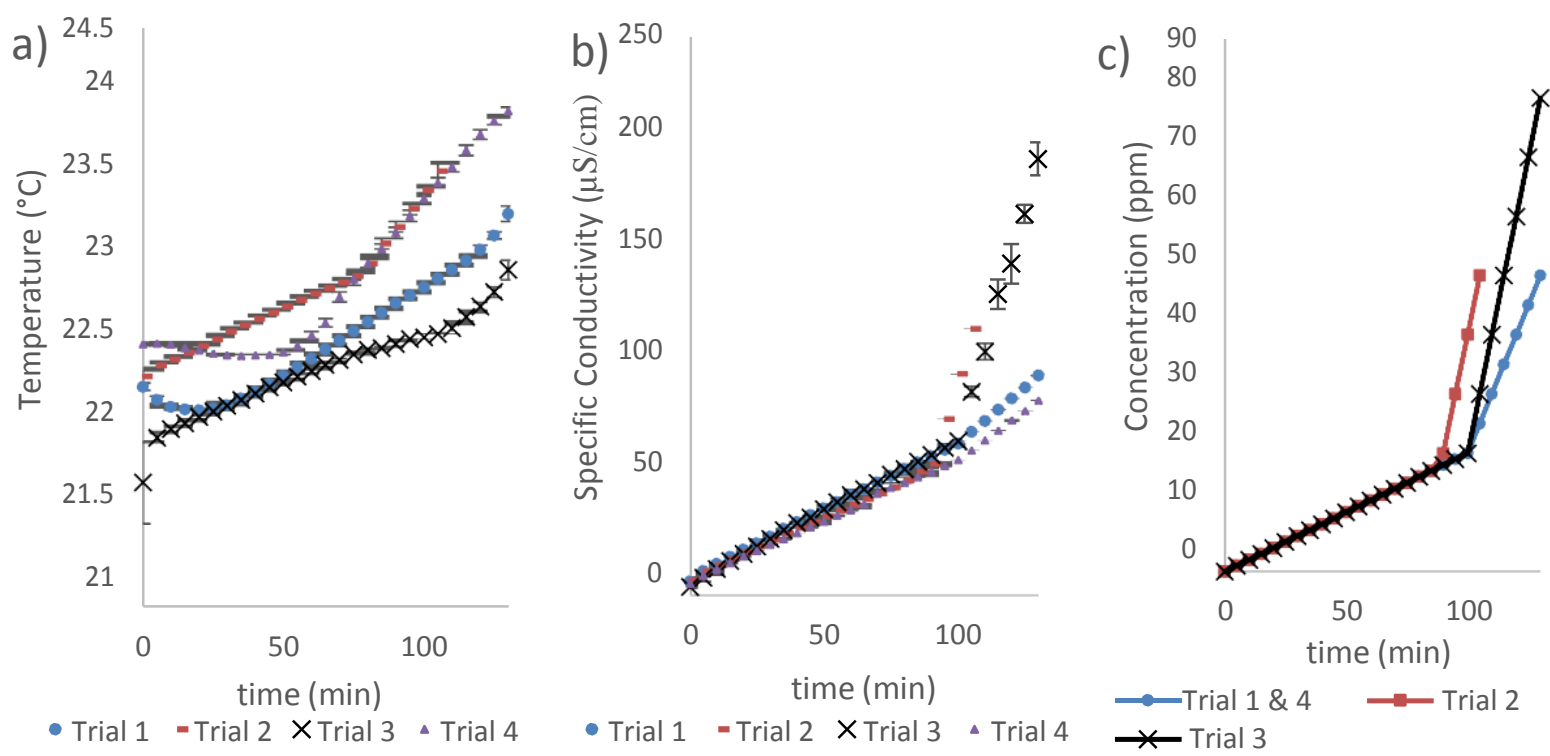

Figure 8 AT results from the produced water trials. a) Temperature, b) specific conductivity and c) the concentration of produced water for these trials.

\subsubsection{Ethylene Glycol}

There were significant differences among the trials for specific conductivity, dissolved oxygen, $\mathrm{pH}$ and oxidation reduction potential (Table 13). This indicates at particular concentrations, the water quality parameter measurements are not unique. Temperature showed some exceptions to being significantly different: Trial 3 for the CS probe showed significant similarity with the other trials; for the AT, Trial 2 showed similarity with the other trials. 
Table 13 Results from the paired t-test comparing the trials of the ethylene glycol tests.

\begin{tabular}{|c|c|c|c|c|c|c|}
\hline \multirow{3}{*}{$\begin{array}{l}\text { Temperature } \\
\text { Trial } 2\end{array}$} & \multicolumn{3}{|c|}{ Campbell Scientific CR 1000} & \multicolumn{3}{|c|}{ AquaTROLL } \\
\hline & Trial 1 & Trial 2 & Trial 3 & Trial 1 & Trial 2 & Trial 3 \\
\hline & $<0.0001$ & & & 0.25 & & \\
\hline Trial 3 & 0.10 & 0.087 & & $<0.0001$ & 0.081 & \\
\hline Trial 4 & 0.0070 & $<0.0001$ & 0.11 & 0.0057 & 0.17 & $<0.0001$ \\
\hline Specific & & & & & & \\
\hline Conductivity & Trial 1 & Trial 2 & Trial 3 & Trial 1 & Trial 2 & Trial 3 \\
\hline Trial 2 & $<0.0001$ & & & $<0.0001$ & & \\
\hline Trial 3 & $<0.0001$ & $<0.0001$ & & $<0.0001$ & $<0.0001$ & \\
\hline Trial 4 & $<0.0001$ & $<0.0001$ & $<0.0001$ & $<0.0001$ & $<0.0001$ & $<0.0001$ \\
\hline pH & Trial 1 & Trial 2 & Trial 3 & & & \\
\hline Trial 2 & $<0.0001$ & & & & & \\
\hline Trial 3 & $<0.0001$ & $<0.0001$ & & & & \\
\hline Trial 4 & $<0.0001$ & $<0.0001$ & $<0.0001$ & & & \\
\hline ORP & Trial 1 & Trial 2 & Trial 3 & & & \\
\hline Trial 2 & $<0.0001$ & & & & & \\
\hline Trial 3 & $<0.0001$ & $<0.0001$ & & & & \\
\hline Trial 4 & 0.15 & $<0.0001$ & $<0.0001$ & & & \\
\hline DO & Trial 1 & Trial 2 & Trial 3 & & & \\
\hline Trial 2 & $<0.0001$ & & & & & \\
\hline Trial 3 & $<0.0001$ & $<0.0001$ & & & & \\
\hline Trial 4 & $<0.0001$ & $<0.0001$ & $<0.0001$ & & & \\
\hline
\end{tabular}

Ethylene glycol did not show any trend in temperature correlation coefficients (Table 14). For the CS, there were three moderate to strong correlations, and three negative weak correlations. For the AT, three trials showed moderate to strong positive correlations but these trials were not the same as the ones that correlated in the CS comparisons. Three AT trials showed weak negative and positive correlations. The apparatus, not the ethylene glycol, was affecting the temperature. For specific conductivity, five correlations were strong and positive in the CS. For the AT, all six of the comparisons of specific conductivity across the trials showed a positive, strong correlation. Specific conductivity may be a valid indicator of ethylene glycol, but it is not a very strong one. $\mathrm{pH}$ for the trials ranged from weak to strong positive correlations, with one negative weak correlation between Trial 2 and Trial 4. The $\mathrm{pH}$ did not appear to converge as it had in the other tested contaminants. Oxidation reduction potential had a negative moderate to strong correlation in all comparisons to Trial 4. The other three comparisons ranged from weak 
to strong positive correlation. The oxidation reduction potential trials appear to have dissimilar rate of change across trials. Dissolved oxygen had four trials with weak positive (1) and negative (3) correlations. Trial 4 showed moderate strong correlation to Trials 1 and 2 . The magnitude of charge for these trials was not very large, on the range of $0.01 \mathrm{ppm}$ oxygen throughout each trial.

Table 14 Correlation coefficients for the water quality parameters across ethylene glycol trials.

\begin{tabular}{|c|c|c|c|c|c|c|}
\hline \multirow[b]{2}{*}{ Temperature } & \multicolumn{3}{|c|}{ Campbell Scientific CR 1000} & \multicolumn{3}{|c|}{ AquaTROLL } \\
\hline & Trial 1 & Trial 2 & Trial 3 & Trial 1 & Trial 2 & Trial 3 \\
\hline Trial 2 & 0.77 & & & 0.030 & & \\
\hline Trial 3 & -0.088 & -0.030 & & 0.82 & -0.086 & \\
\hline Trial 4 & 0.78 & 1.0 & -0.039 & 0.75 & -0.12 & 0.98 \\
\hline Spec & & & & & & \\
\hline $\begin{array}{l}\text { Conductivity } \\
\text { Trial } 2\end{array}$ & $\begin{array}{c}\text { Trial } 1 \\
0.99\end{array}$ & Trial 2 & Trial 3 & $\begin{array}{c}\text { Trial } 1 \\
0.88\end{array}$ & Trial 2 & Trial 3 \\
\hline Trial 3 & 1.0 & -0.27 & & 1.0 & 0.87 & \\
\hline Trial 4 & 0.99 & 0.97 & 0.99 & 0.99 & 0.85 & 1.0 \\
\hline pH & Trial 1 & Trial 2 & Trial 3 & & & \\
\hline Trial 2 & 0.61 & & & & & \\
\hline Trial 3 & 0.99 & 0.45 & & & & \\
\hline Trial 4 & 0.99 & -0.33 & 0.45 & & & \\
\hline ORP & Trial 1 & Trial 2 & Trial 3 & & & \\
\hline Trial 2 & 0.67 & & & & & \\
\hline Trial 3 & 0.44 & 0.22 & & & & \\
\hline Trial 4 & -0.61 & -0.98 & -0.96 & & & \\
\hline DO & Trial 1 & Trial 2 & Trial 3 & & & \\
\hline Trial 2 & 0.27 & & & & & \\
\hline Trial 3 & -0.11 & -0.14 & & & & \\
\hline Trial 4 & 0.090 & 0.80 & -0.49 & & & \\
\hline
\end{tabular}

Ethylene glycol impact on water quality parameters

The average dissolved oxygen did not substantially change throughout the trials, but consistently showed a standard deviation of about $0.5 \mathrm{ppm} / 5$ minute time step. This is an indication of unstable readings, a phenomena not observed in the produced water or drilling mud laboratory tests. The specific conductivity had a positive trend with the addition of ethylene glycol, at a rate of about 0.1 to $0.2 \mu \mathrm{S} / \mathrm{cm}$ per minute, except in Trial 2 where the rate of increase 
was $0.42 \mu \mathrm{S} / \mathrm{cm}$ per minute. The $\mathrm{pH}$ did not converge in the glycol trials, but each trial had a decreasing linear trend of about -0.0003 to -0.01 units/min (Figure 9). The oxidation reduction potential had two trials around $400 \mathrm{mV}$, and two trials around $-50 \mathrm{mV}$. All trials showed a trend towards zero, but at neither large nor consistent rates. $\mathrm{pH}$ and oxidation reduction potential did not respond consistently among the trials.
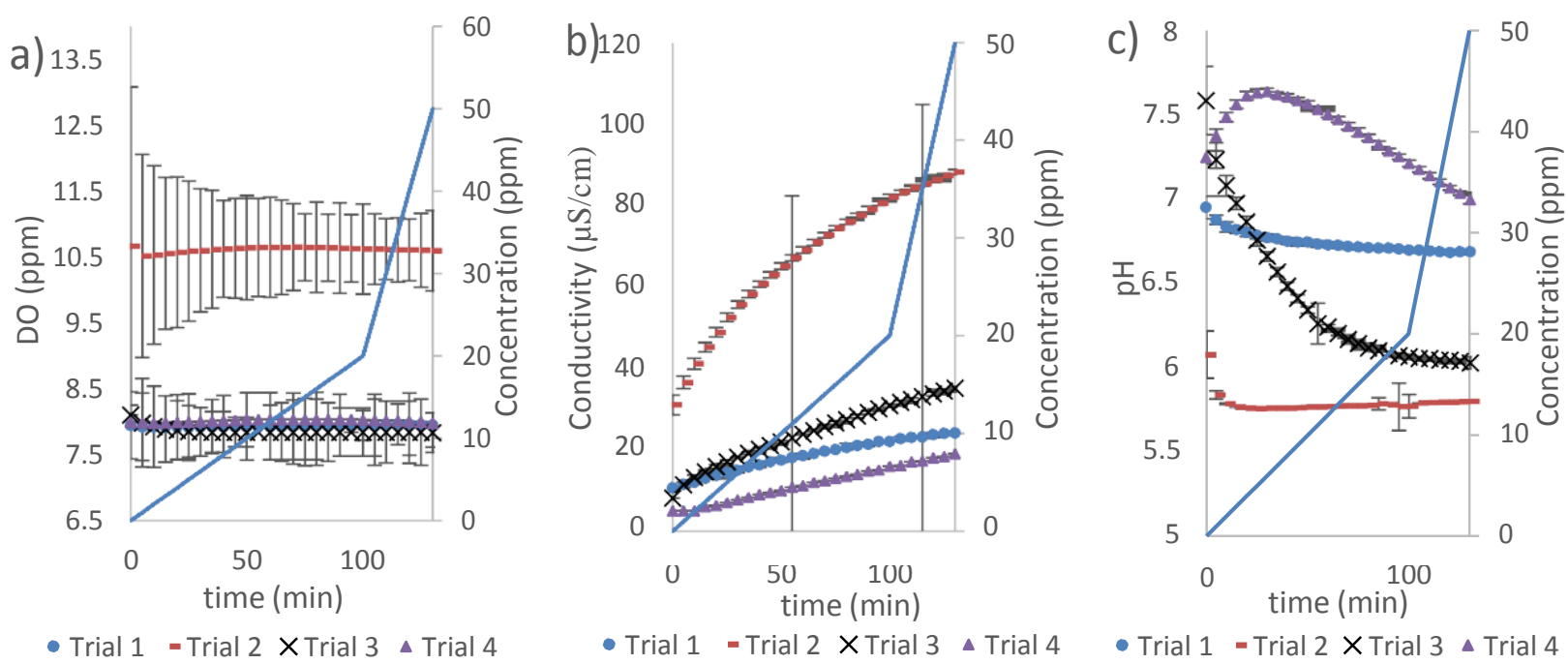

- Trial 1 -Trial $2 \times$ Trial $3 \Delta$ Trial 4

- Trial 1 - Trial $2 \times$ Trial $3 \Delta$ Trial 4
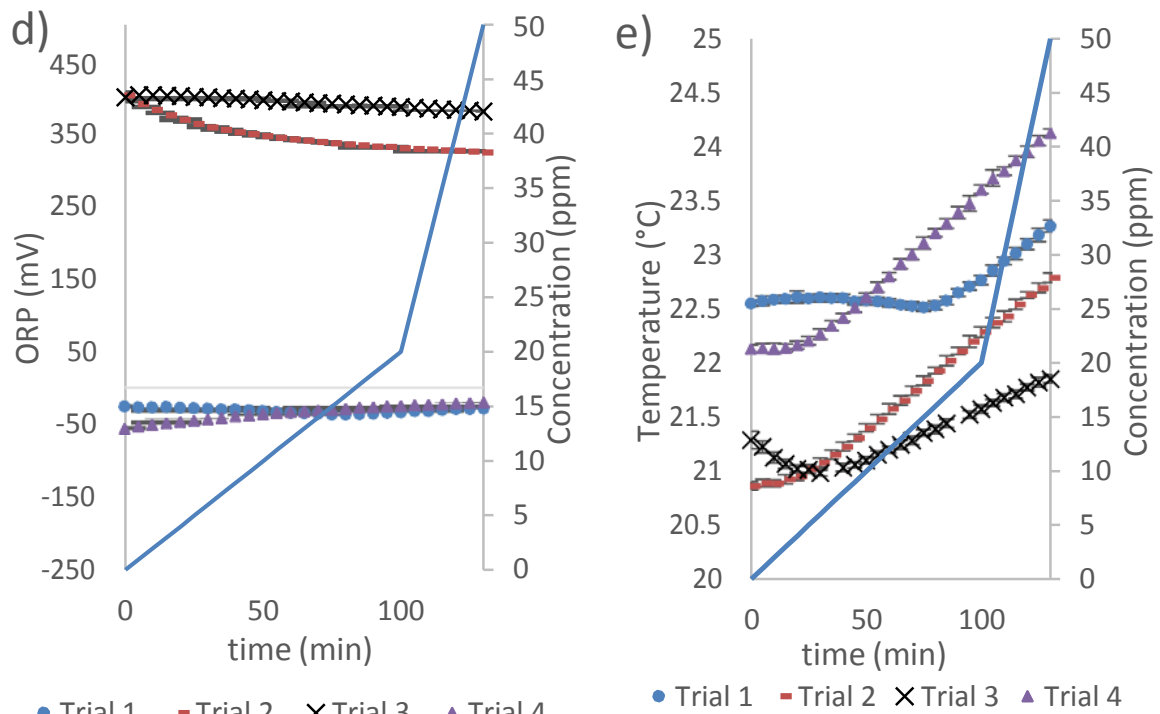

- Trial 1 -Trial $2 \times$ Trial $3 \Delta$ Trial 4

- Trial 1 -Trial $2 \times$ Trial $3 \Delta$ Trial 4

Figure 9 CS measurements from ethylene glycol experiments. a) dissolved oxygen, b) specific conductivity, c) $\mathrm{pH}, \mathrm{d}$ ) oxidation reduction potential, and e) temperature over time. Concentration is shown with a solid line. 
The results from the AT measurements of ethylene glycol are in Figure 10. There appears to be some type of environmental disturbance that occurred in the fourth time step of the second trial. Both the CS and AT show elevated temperature, and in the case of the AT the specific conductivity reading was zero. This may have been interference from the magnetic stirrer, but the reason for these high readings are unknown.
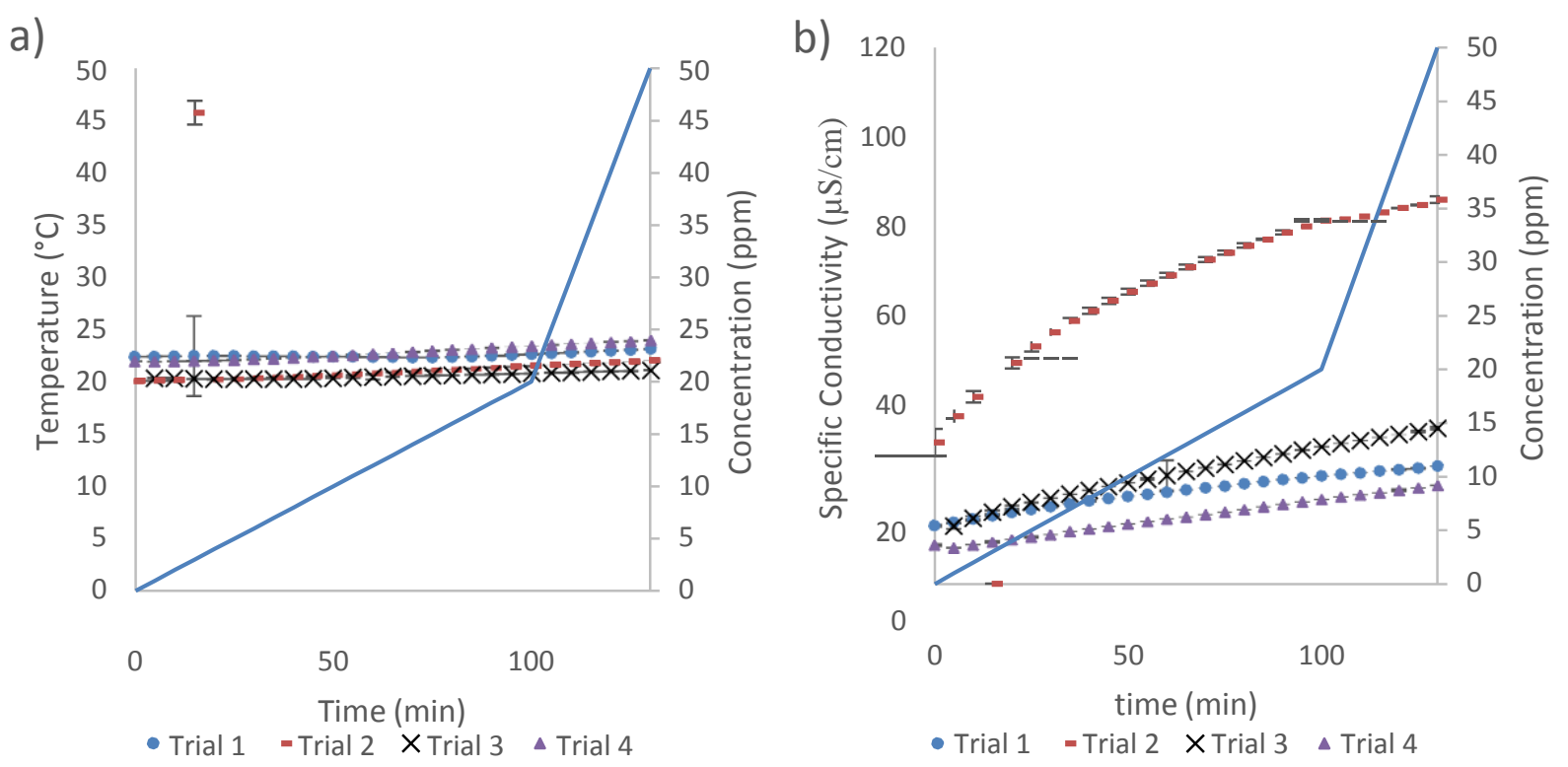

Figure 10 Results from the AquaTROLL for the ethylene glycol trials. a) Temperature, and b) specific conductivity over time. The concentration is represented with a solid line.

\subsubsection{Comparing the cross-instrument similarities}

The Campbell Scientific measures more parameters at a higher frequency than the AquaTROLL. The two similar parameters, specific conductivity and temperature, are compared for the consistency of their measurements between the two instruments (Table 15). 
Table 15 p-values and correlation coefficients between the Campbell Scientific and AquaTROLL sensors for the laboratory experiments.

\begin{tabular}{llcccc}
\hline Drilling Mud & & Trial 1 & Trial 2 & Trial 3 & Trial 4 \\
p-value & Specific Conductivity & $<0.0001$ & $<0.0001$ & $<0.0001$ & $<0.0001$ \\
& Temperature & $<0.0001$ & $<0.0001$ & $<0.0001$ & $<0.0001$ \\
correlation coefficienn & Specific Conductivity & 1.0 & 1.0 & 0.99 & 1.0 \\
& Temperature & 1.0 & 1.0 & 1.0 & 1.0 \\
\hline Produced Water & & Trial 1 & Trial 2 & Trial 3 & Trial 4 \\
p-value & Specific Conductivity & $<0.0001$ & $<0.0001$ & $<0.0001$ & $<0.0001$ \\
& Temperature & $<0.0001$ & $<0.0001$ & $<0.0001$ & $<0.0001$ \\
correlation coefficient & Specific Conductivity & 1.0 & 1.0 & 1.0 & 1.0 \\
& Temperature & 1.0 & 1.0 & 1.0 & 1.0 \\
\hline Ethylene Glycol & & Trial 1 & Trial 2 & Trial 3 & Trial 4 \\
p-value & Specific Conductivity & $<0.0001$ & $<0.0001$ & $<0.0001$ & $<0.0001$ \\
& Temperature & $<0.0001$ & 0.39 & 0.071 & $<0.0001$ \\
correlation coefficient & Specific Conductivity & 0.99 & 0.97 & 1.0 & 1.0 \\
& Temperature & $\underline{1.0}$ & $\underline{-0.12}$ & -0.089 & $\underline{1.0}$ \\
\cline { 2 - 3 } & & & & &
\end{tabular}

The instruments consistently failed the paired t-test in drilling mud and produced water trials in both specific conductivity and temperature, indicating that the trials were significantly different. The p-value for the CS and AT measurements of temperature for the second and third trial of ethylene glycol showed significant similarity. The correlation in these two trials, however, was weak and negative. This is anomalous to the strong positive correlation of the two instruments in temperature for all the chemicals. Specific conductivity also showed strong correlation across all Trials in all chemicals.

\subsection{Discussion}

\subsubsection{Instrument response to chemicals}

In the case studies, it was shown that when contaminants travel in watersheds, peak concentration after $16 \mathrm{~km}$ (10 miles) of travel is on the order from less than $1 \mathrm{ppm}$ to approximately $3 \mathrm{ppm}$. In smaller travel distances, such as less $1.6 \mathrm{~km}$ (1 mile) of travel, $50 \mathrm{ppm}$ is possible. Even at low concentrations, the contaminants ethylene glycol, produced water, and drilling mud have predictable effects on water quality parameters (Table 16). 
Table 16 Summary of the water quality parameters that were affected by low concentrations of contaminants. $($ nt. $=$ no observed trend)

\begin{tabular}{llll}
\hline & \multicolumn{1}{c}{ Drilling mud } & Produced water & Ethylene glycol \\
\hline $\begin{array}{l}\text { Specific } \\
\text { Conductivity }\end{array}$ & $\begin{array}{l}\text { increased by an average of } \\
21 \mu \mathrm{S} / \mathrm{cm} \text { per } 50 \mathrm{ppm} .\end{array}$ & $\begin{array}{l}\text { increased by an average } \\
\text { of } 101 \mu \mathrm{S} / \mathrm{cm} \text { per } 50 \mathrm{ppm}\end{array}$ & $\begin{array}{l}\text { increased by an average of } \\
27 \mu \mathrm{S} / \mathrm{cm} \text { per } 50 \mathrm{ppm}\end{array}$ \\
\hline $\mathrm{pH}$ & $\begin{array}{l}\text { decreased to an average } \\
\text { value of } 6.27\end{array}$ & $\begin{array}{l}\mathrm{pH} \text { decreased to an } \\
\text { average value of } 6.57\end{array}$ & $\mathrm{nt}$. \\
\hline $\mathrm{DO}$ & $\begin{array}{l}\text { decreased at a rate of } 0.08 \\
\text { ppm per } 1 \mathrm{ppm} \\
\text { contaminant }\end{array}$ & nt. & $\begin{array}{l}\text { Variance in dissolved } \\
\text { oxygen values was } 1 \mathrm{ppm}, \\
\text { though average value did } \\
\text { not change. }\end{array}$ \\
\hline ORP & nt. & $\begin{array}{l}\text { Oxidation reduction } \\
\text { potential had a unique } \\
\text { shape in the measurement } \\
\text { curve }\end{array}$ & nt. \\
\hline
\end{tabular}

Specific conductivity was a useful indicator for the contaminants, with $5 \mathrm{ppm}$ concentration of the produced water being significant enough to diverge from a signal that would be expected from a rain event. $\mathrm{pH}$ was a useful proxy indicator for produced water and drilling mud at low concentrations, and dissolved oxygen was affected by drilling mud and ethylene glycol. This means that these water quality parameters may be useful indicators for these types of spill events.

These water quality parameters are prevalently measured in water quality monitoring systems. Using these parameters as proxy indicators is an advantage to chemical manufacturers or industries, as these values can be reported without revealing proprietary information. This information may be provided in material data sheets so that if a spill monitoring program was to be established, the expected effects on surface water quality can be easily identified. 


\subsubsection{The placement of monitoring systems}

The likelihood that a contaminant would be detected depends on the peak concentration as it reaches a monitoring station. It was found the decrease in peak concentration of a contaminant is most related to the distance that the chemical travels. This change in concentration is because dispersion affects plume distribution. In the case studies, as shown in Figure 11, it was found that 50 barrel spills showed a persistent concentration of more than 1 ppm in medium and small watersheds (approximately $65-120 \mathrm{~km}^{2}$ or $25-45 \mathrm{mi}^{2}$ ). The size of the drainage area affects the peak concentration of the contaminant, even when the travel distance and volume is the same. This is because the discharge volume is a factor for the dilution of the contaminant. It was shown that even small spills may persist at a higher concentration during short travel distances. For the average spill volume of 34 barrels, a detectable peak concentration may persist only $800 \mathrm{~m}$. Over greater distances, the contaminant plume becomes dispersed, so the length of the contaminant signal will be more prevalent than its magnitude.

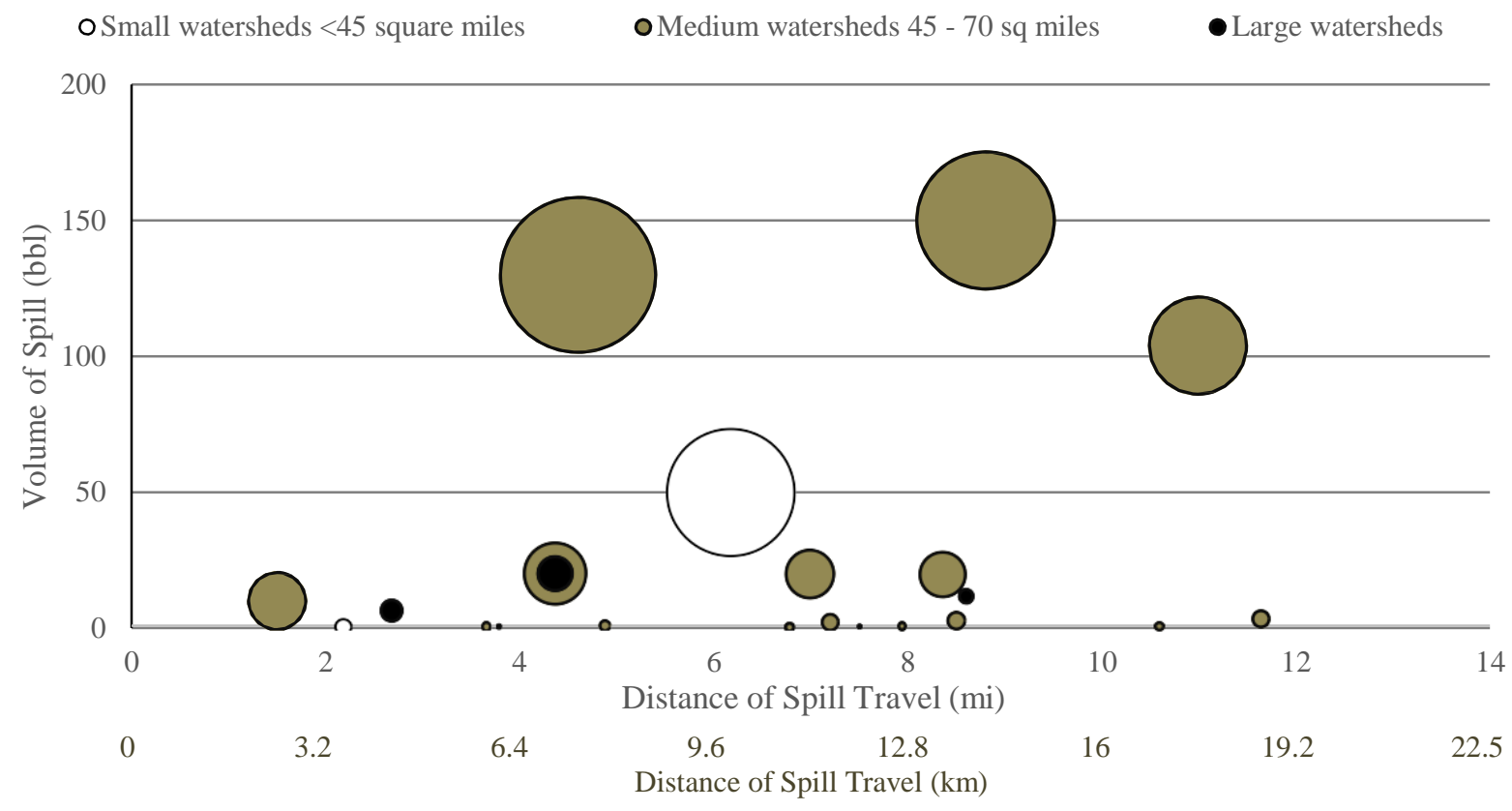

Figure 11 The volume of the bubbles represent the peak concentration found at the monitoring station for each case study, the largest bubble being about $1.5 \mathrm{ppm}$. 
It is recommended to observe the rate of change for water quality parameters rather than for a threshold value. This would require that the measurement frequency should be sized by the river geometry that dictates contaminant velocity, which is channel slope, discharge, and the distance of travel for possible spills. If data storage is a limiting factor in the cost-effectiveness of water quality instruments, then a standard deviation from the average of several scans should be used. Of the case studies, most examples were found in medium sized watersheds (about 130 $\mathrm{km}^{2}$ or $50 \mathrm{mi}^{2}$ ). A medium sized drainage area may be sufficient to encompass several spill risks without diluting the contaminants beyond spill detections. Fifty barrel spills can be detected over distances greater than $10 \mathrm{~km}$ (about $6 \mathrm{mi}$ ) in even the large watersheds (about $260 \mathrm{~km}^{2}$ or 100 $\left.\mathrm{mi}^{2}\right)$.

Sometimes the frequency of data collection is based on what is cost-effective for the monitoring agency. Higher frequency measurements require data storage and more battery power, but current technology in remote systems - telemetric communication and solar power sources - can make more frequent measurements possible. Still, the monitoring frequency depends on the objective of the monitoring program. When it comes to spill detection, the monitoring frequency should be high enough to confirm that changing water quality is associated with a spill plume. It is recommended the frequency should allow for 5 measurements over an empirical estimation of the duration of a possible spill's residence time. In the SRBC RWQMN watersheds, the measuring frequency is every 4 hours. Four hours may not be a sufficient frequency in the case of the Little Muncy spill event, whose spills' residence time was 12 hours. Though a change in water quality was evident, more measurement events could confirm a characteristic concentration lead time, peak, and lag. The frequency of the measurements may be 
dependent on the travel time from the monitoring location to a protected source water area. The time required to report a spill detection can be incorporated into an emergency action plan.

In the laboratory, the experiments demonstrated that it was difficult to repeat the trials and achieve the same water quality parameter values. The water quality at the beginning of the experiments varied, and temperature variations can affect the baseline measurements for the instruments. In the field, it would be expected that the sensors would be under similar external effects, as the water system is subject to the weather. Monitoring for change may be more effective, because there were significant correlations of water quality parameters with increasing concentration.

\section{Environmental effects on water quality parameters}

In addition to the presence of contaminants, there are natural phenomena that could occur in the environment that affect water quality parameters. Conductivity and $\mathrm{pH}$ decrease with river discharge because groundwater base-flow is a significant contributor to total dissolved solids, and increased discharge dilutes these effects (Caissie et al. 1996, Sawyer et al. 2009). Run-off from a rain event is also a source of dissolved solids, which may have ions that affect conductivity and $\mathrm{pH}$. Literature shows that this change can be up to $25 \mu \mathrm{S} / \mathrm{cm}$ and 0.8 units, these changes correspond to the increasing discharge immediately after a storm event (Caissie et al. 1996)

Dissolved oxygen experiences diurnal variations due to biological activity. Variations could also be seasonal, as temperature affects the maximum oxygen saturation. Studies have found that the magnitude of change due to diurnal variations may be on the order of $0.32 \mathrm{ppm}$ in the winter months and $1.5 \mathrm{ppm}$ in the summer the shift occurring during the daylight hours (Guasch et al. 1998, Mulholland et al. 2005). 


\section{Identifying a spill signal from the case studies, and more recommendations}

Of the twenty-two case studies, five occurred when the monitoring network was offline, not recording data. Because spills will probably be unexpected, it is imperative to decrease the downtime of sensors. Of the remaining nineteen case studies, three of the spills were diesel fuel spills, which were not measured in the laboratory study. The recommendation would be to do an analysis of the contaminants most likely to be spilled in a watershed to ensure detection is possible. This can possibly be taken upon the manufacturer of the chemical to provide information of the water quality parameter measurements of the chemical in concentrated or in its waste stream concentration. Of the remaining sixteen case study spills, it was found that the detectable response in the watershed occurred where the calculated peak concentration was greater than $1 \mathrm{ppm}$. The contaminant events were from produced water spills with magnitudes of one hundred barrels.

The signal was identified from a 130 barrel produced water spill that occurred in July 2014 in Little Muncy Creek (Figure 12). The monitoring station is located about $8 \mathrm{~km}$ (5 mi) downstream of the spill location. The empirical value for the time of travel for the peak concentration is about four days, and the length of time for the spill to be present is about 12 hours (Jobson 1996). The actual travel time may be over-estimated because the slower rate of transport during the contaminants period as run-off and in headwater streams.

As discussed earlier, produced water has proxy indicators of higher conductivity and lower $\mathrm{pH}$ than baseline water quality. A signal was identified to occur two weeks after the spill event, as shown in Figure 12. The water quality signal shown is identified as a produced water spill event rather than a rain event, because the $\mathrm{pH}$ decreases. 


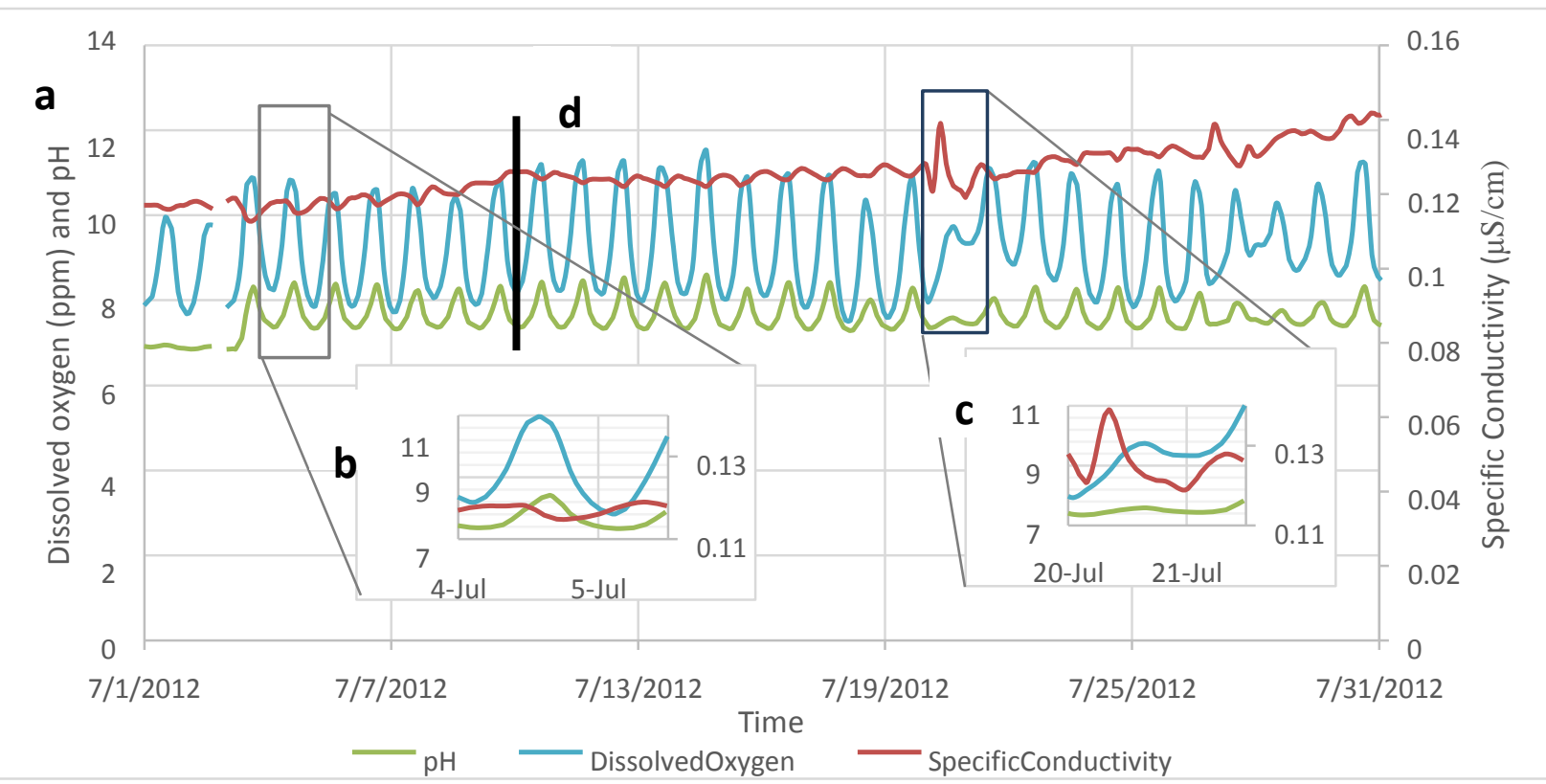

Figure 12 Little Muncy Creek pH, DO and specific conductivity. Data collected from SRBC RWQMN. A) July 1 to July 31, 2014; B) July 3 at 12:00PM to July 5 at 4:00 PM; C) July 19 at 12:00 PM to July 21 at 4:00 PM; D) earliest arrival time predicted by empirical methods.

There was not enough information to validate this observation: it is recommended that the precipitation information is collected on a watershed basis, so that signals from rain events may not be confused with a contaminant spill. It would also be helpful for a secondary system, such as passive sampler or another sensor that can provide more information about the water quality as it passes to confirm whether it is indeed an unnatural contaminant affecting water quality.

In determining the placement of spill detection systems, the water systems manager would have to decide: what is the volume of a significant spill that warrants observation? (According to literature, a 9.5 barrel spill is significant, Brantley et al. 2014). Then the placement of the monitoring system should be within a drainage area and a travelling distance that would allow for the target concentration to be at least 1 to $5 \mathrm{ppm}$. 


\subsection{Conclusion}

The hydrologic models and water quality monitoring experiments developed in this chapter demonstrates how spill detections programs can be optimized on watershed geometry. It was found that water quality change due to contaminants traveling in a stream system is possible with the use of current in-stream technology. The volume of the contaminant and its distance traveled were important parameters affecting the peak concentration, and are important considerations for sizing a spill detection program. Water quality managers may consider the volume of chemical storage, the watershed characteristics such as channel slope and travel distances, along with personal priorities of risk, such as chemical toxicity or regulatory requirements.

Monitoring stations can be adapted for spill detection by increasing the frequency of their measurements, or if that is not possible, at least recording the standard deviation. It is recommended to develop technology to validate the presence of a contaminant versus natural fluctuations in water quality. Filtering out the baseline water quality from diurnal fluctuations would be helpful for identifying a divergence from environmental. In summary, current continuous monitoring technology may be effective in detecting surface water spills, but like all successful water quality monitoring program, the placement and measurement must be adapted to make the data informative. 


\subsection{Three-Dimensional Modeling the Elk River spill in Charleston, WV}

\subsection{Background}

On January 9, 2014 Freedom Industries, Inc., a specialty chemical distributor in Charleston, WV, had a catastrophic spill at a storage facility located on the left bank of the Elk River. A chemical, 4-methylcyclohexanemethanol (MCHM), leaked from an above ground storage tank, breached containments, and entered into the Elk River. The American Water public water intake facility for the Charleston area was located about $2.6 \mathrm{~km}$ (1.6 mi) downstream from the spill site (Figure 13). The water intake and treatment facility became overwhelmed by the loading of the chemical. The chemical was distributed through the water infrastructure into public water supply, and disrupted the water quality of up to 300,000 residents (Cooper 2014). MCHM is a chemical used a froth-flotation agent to separate ash from coal (Christie et al. 1990). An estimated that 10,000 gallons of MCHM was lost at a rate of approximately 8 gallons per minute over 20 hours (Boucher 2014). Eyewitnesses reported that the MCHM appeared to cling to the left-side of the river bank as it traveled downstream (Whelton 2015).

When a chemical undergoes transport in a body of water, its chemical properties and the hydrologic properties of the river influence the rate of chemical dispersion. For example, advection or the bulk movement of fluid is determined by the discharge of the waterbody; the contaminant's velocity and dispersion properties is a function of the slope of the channel, the velocity of the water, and its depth. The fate of the chemical influences the magnitude of risk and the amount of time it will be present in the watershed. The location of a chemical right after a spill is integral to designing strategies for risk mitigation. If the chemical settles in the sediment, or volatilizes very quickly, then a local remediation is needed to address the extent of the spill. Very dispersive chemicals have a high area of influence, and it is more difficult to contain the 
chemical as time progresses. A three-dimensional model demonstrates the dispersion of a chemical in time and space, and can be applied to mitigation and early-detection techniques.

The objective of this study was to develop a three-dimensional model of the Elk River, above the spill location to the water intake facility. The model incorporated extended chemical loading in two phases: floating on the river surface and dissolved within the surface water. The model simulated based on hydrologic dispersion and diffusion as well as the chemical properties volatilization and solubility.

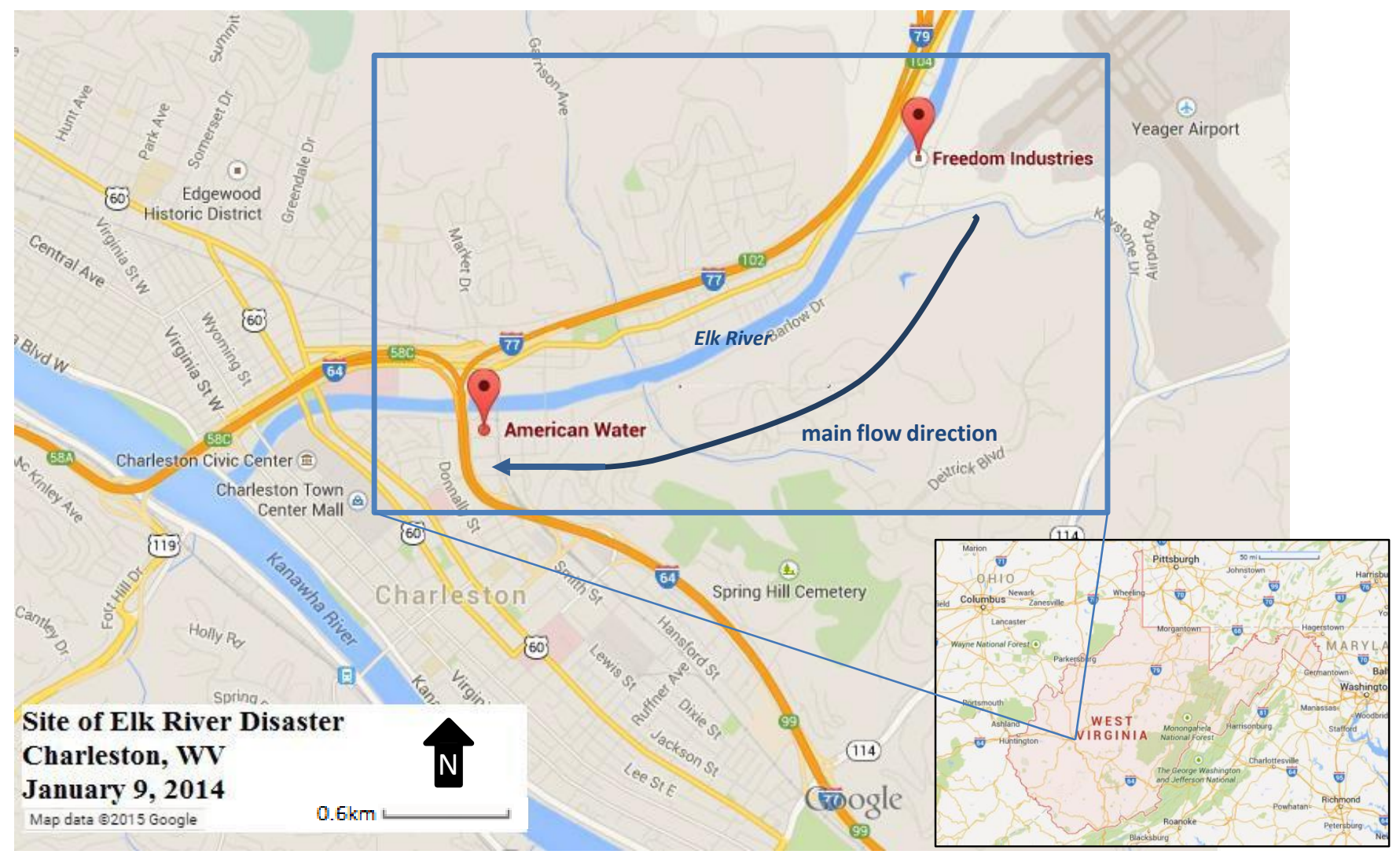

Figure 13 Elk River spill location at Freedom Industries, Inc. and the water way to the Charleston WV public water intake, American Water. 


\subsubsection{Current Modeling Techniques}

Existing non-aqueous phase liquid models, most available free to the public from the US EPA, cover the vadose zone and groundwater systems, and there are other models capable of simulating chemical and water quality changes in surface water systems (Table 20). The groundwater models are limited in their ability to estimate the transport of contaminants in surface waters, and surface water system models are either specialized in the type of contaminants (i.e. QUAL2E) or require an external hydrodynamic model for transport calculations (i.e. WASP). 
Table 17 Models currently available for simulating chemical properties and environmental fate and transport of non-aqueous-phase liquids.

\begin{tabular}{|c|c|c|c|}
\hline Model [Source] & Regime & Capabilities & Limitations \\
\hline $\begin{array}{l}\text { Non-aqueous-phase } \\
\text { liquid (NAPL) } \\
\text { Simulator } \\
\text { [US EPA, 2015c] }\end{array}$ & $\begin{array}{l}\text { Atmosphere and vadose } \\
\text { zone interface, to } \\
\text { capillary and aquifer } \\
\text { water Table interface. }\end{array}$ & $\begin{array}{l}\text { Transport of } 3 \text { phases; 2-D } \\
\text { and 3-D simulation. Uses } \\
\text { finite-difference numerical } \\
\text { solution. Can incorporate } \\
\text { volatilization and } \\
\text { dissolution with rate- } \\
\text { limited mass transfer }\end{array}$ & $\begin{array}{l}\text { Does not consider } \\
\text { surface water flow. }\end{array}$ \\
\hline $\begin{array}{l}\text { BIOCHLOR and } \\
\text { other } \\
\text { biological/remediat } \\
\text { i on models } \\
\text { [USEPA 2015c] }\end{array}$ & $\begin{array}{l}\text { Chemical transport in } \\
\text { aquifers and the vadose } \\
\text { zone for remediation } \\
\text { decision-making. }\end{array}$ & $\begin{array}{l}\text { 1-D advection, 3-D } \\
\text { dispersion, adsorption, } \\
\text { decay and transport of } \\
\text { chemicals, water quality } \\
\text { variables. } \\
\text { Uses finite difference, first } \\
\text { order decay, and analytical } \\
\text { solutions. }\end{array}$ & $\begin{array}{l}\text { Does not consider } \\
\text { surface water flow. }\end{array}$ \\
\hline $\begin{array}{l}\text { Hydrocarbon spill } \\
\text { screening model } \\
\text { (HSSM) } \\
\text { [USEPA 2015c] }\end{array}$ & $\begin{array}{l}\text { Ground surface to water } \\
\text { Table, including } \\
\text { capillary fringe and } \\
\text { advection in the } \\
\text { saturated zone. Multiple } \\
\text { phases and chemical } \\
\text { properties. }\end{array}$ & $\begin{array}{l}\text { 1-D in vadose zone, radial } \\
\text { in capillaries, } 2-\mathrm{D} \\
\text { dissolution and aquifer } \\
\text { transport. }\end{array}$ & $\begin{array}{l}\text { Does not consider } \\
\text { surface water flow. }\end{array}$ \\
\hline $\begin{array}{l}\text { 2-D Finite element } \\
\text { program for } \\
\text { multiphase flow and } \\
\text { multicomponent } \\
\text { transport (MOFAT) } \\
\text { [USEPA 2015c] }\end{array}$ & $\begin{array}{l}\text { Saturated zone and } \\
\text { unsaturated zone flow } \\
\text { and transport of solutes. }\end{array}$ & $\begin{array}{l}\text { Flow of up two } 3 \text { phases: } \\
\text { explicit } 3 \text {-phase flow in } \\
\text { water, semi-steady state of } \\
\text { 2-phase flow. Solved by } \\
\text { first order kinetics or local } \\
\text { equilibrium. }\end{array}$ & $\begin{array}{l}\text { Does not consider } \\
\text { surface water flow. }\end{array}$ \\
\hline $\begin{array}{l}\text { Enhanced stream } \\
\text { water quality model } \\
\text { (QUAL2E) } \\
\text { [Brown and } \\
\text { Barnwell 1987] }\end{array}$ & $\begin{array}{l}\text { Chemical and water } \\
\text { quality variables as } \\
\text { affected by advection } \\
\text { and dispersion in } \\
\text { streams. }\end{array}$ & $\begin{array}{l}\text { 1-D; Steady state chemical } \\
\text { distribution; Solved with } \\
\text { backward difference } \\
\text { scheme, using finite } \\
\text { difference solution. }\end{array}$ & $\begin{array}{l}\text { One dimensional } \\
\text { surface water flow, only } \\
\text { analyzes for } \\
\text { conventional pollutants } \\
\text { and water quality } \\
\text { parameters. }\end{array}$ \\
\hline $\begin{array}{l}\text { Estimation Program } \\
\text { Interface (EPI) } \\
\text { Suite } \\
\text { [US EPA 2012b] }\end{array}$ & $\begin{array}{l}\text { Determines intrinsic } \\
\text { chemical properties such } \\
\text { as Henry's law constant } \\
\text { and phase partition } \\
\text { coefficients as a } \\
\text { screening tool. }\end{array}$ & $\begin{array}{l}\text { Physical and chemical } \\
\text { equations from chemical } \\
\text { structure. }\end{array}$ & $\begin{array}{l}\text { Does not consider } \\
\text { contaminant transport. }\end{array}$ \\
\hline $\begin{array}{l}\text { Water quality } \\
\text { analysis simulation } \\
\text { program(WASP) } \\
\text { [DiToro et al. 1983] }\end{array}$ & $\begin{array}{l}\text { Surface water quality } \\
\text { due to natural } \\
\text { phenomena and man- } \\
\text { made pollution. }\end{array}$ & $\begin{array}{l}1-, 2-, 3-\mathrm{D} \text { simulation, } \\
\text { incorporating flows and } \\
\text { river dimensions. } \\
\text { Compartment-modeling, } \\
\text { numerical integration. }\end{array}$ & $\begin{array}{l}\text { Requires an external } \\
\text { hydrodynamic model to } \\
\text { solve for advection. } \\
\text { Cannot estimate } \\
\text { dispersion coefficients } \\
\text { and temperature. }\end{array}$ \\
\hline
\end{tabular}


In order to quantify the dispersion of MCHM for future risk mitigation, a new finite difference model was developed. The three-dimensional model represented the spill location and the length of the river to the American Water facility in Charleston. The model calculated the contaminant concentration according to the chemical loading rate and the dispersion properties and geometry. The contaminant distribution shows the critical zone for mitigation at the spill site and the vulnerability of the water facility intake under different loading scenarios.

\subsubsection{Surface water mixing mechanisms}

MCHM has a specific gravity of 0.9074 (US EPA 2012b). It is therefore likely that it floated like a film on the river surface. In the model, MCHM was treated as two phases: a concentrated layer floating on the river surface, and a dissolved contaminant in the water column. There are several phenomena that affect the dispersion of a chemical in a surface water system (Figure 14). Some are attributed to the velocity and the depth of the body of water, these are called hydrologic dispersion mechanisms. Other phenomena are attributed to the chemical and physical properties of the pollutant, which affects its solubility in the river and its absorption in the sediment that line the river system. 


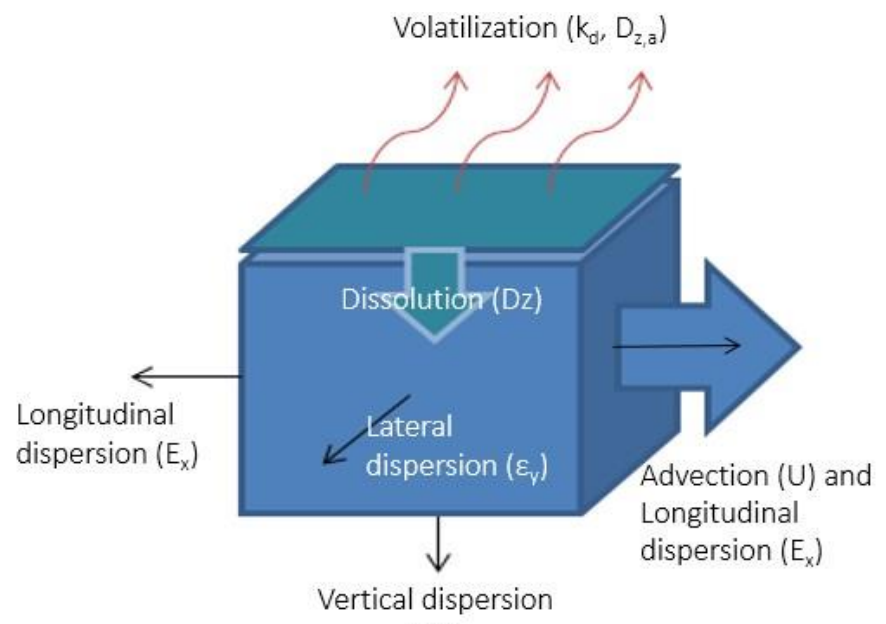

$\left(\varepsilon_{2}\right)$

Figure 14 Mechanisms of dispersion of a light non-aqueous phase liquid (LNAPL) in a control volume, represented in a cross-section is the Elk River at the American Water Systems intake.

In this model, the y-direction refers to the lateral direction, perpendicular to the river banks; the z-direction refers to depth, perpendicular to river surface, positive down from the surface; and the x-direction parallel to the river banks, positive in the downstream direction. The mechanisms of dispersion that affect the concentration of the LNAPL that were used in the model follow:

1.Advection of the chemical with the flow of surface water. The chemical that is floating on the water surface and within the water column is carried by the bulk movement of water (equation 5).

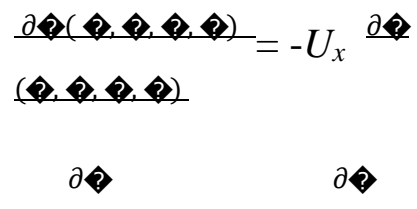

where $C=$ concentration of chemical $\left(\mathrm{kg} / \mathrm{m}^{3}\right)$; $t=$ time $(\mathrm{hr}) ; U_{x}=$ river velocity $(\mathrm{m} / \mathrm{hr})$ in the $\mathrm{x}$ direction.

It is assumed that the floating LNAPL is moving with the bulk river flow, not "slipping" 
across the surface. This allows for one velocity term in the main flow direction. 
2.Volatilization of the chemical at the LNAPL and atmosphere interface. The MCHM has a specific gravity of 0.9047 , which likely causes it to float on the river surface. The chemical is directly exposed to the atmosphere for an extended period of time. Because of advection, it was assumed that the atmosphere and the chemical did not reach equilibrium; the air above the chemical was moved away by wind or advection while not becoming saturated by the chemical. Therefore, the loss of LNAPL to the atmosphere was a rate limited process, where mass was transferred at a constant transfer coefficient, $\mathrm{k}_{\mathrm{d}}$ :

$$
\begin{aligned}
\mathrm{W} \text { he } \mathrm{n} \mathrm{z}=0, & -D_{z, a}-k_{d}\left[C_{g}(\mathrm{t}, \mathrm{x}, \mathrm{y},\right. \\
\left.0)-C_{g}(\mathrm{t}, \mathrm{x}, \mathrm{y}, \infty)\right]=0 & \text { (6) }
\end{aligned}
$$

where $z=$ elevation $(\mathrm{m})$, in this case the water surface; $D_{z, a}=$ rate of volatilization $(\mathrm{kg} / \mathrm{hr}) ; k_{\nu} \mathrm{d}=$ transfer coefficient $(\mathrm{m} / \mathrm{hr}) ; C_{g}=$ concentration of chemical in the gaseous phase $\left(\mathrm{kg} / \mathrm{m}^{3}\right)$.

The saturated gas coefficient was determined by a combination of Henry's law and the vapor pressure of the chemical (Henry 1803; USAEPA 2012b):

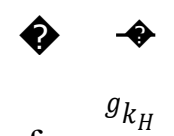

where $P=$ the vapor pressure (units of pressure); $k_{H}=$ Henry's law constant (units of pressure/concentration). 
The mass transfer coefficient can be estimated based on the molecular weight of the chemical of interest, while also considering the contribution of wind and water to its transfer rate (Southworth 1979):

$$
\left.k_{\diamond}=1137.5(2)+2>r\right) \sqrt{18} / M(8)
$$

where $k_{G}=$ gas phase mass transfer $(\mathrm{cm} / \mathrm{hr}) ; V_{\text {wind }}$ and $V_{\text {curr }}=$ velocity of wind and river current respectively $(\mathrm{m} / \mathrm{s}) ; M=$ molecular weight of the chemical of interest $(\mathrm{g} / \mathrm{mol})$.

The molecular weight and physical properties of MCHM were determined by the EPA Estimation Program Interface (USEPA 2012b); which uses the chemical structure of molecules to estimate other physical properties such as solubility and vapor pressure.

3.Dissolution of the chemical at the LNAPL at the water surface interface. Within this simulation, there were two distinct phases for the LNAPL: (1) the phase where it was floating on top of the water column, and (2) the phases as it was dissolved into the water column. At the floating LNAPL and water interface, it was assumed that the phases are in persistent contact and in equilibrium, limited by the maximum solubility of the MCHM to water.

4.Longitudinal dispersion of the dissolved LNAPL. Longitudinal dispersion is created by the advective velocity moving the chemicals into and within the water column. The dispersion coefficient $\left(\mathrm{E}_{\mathrm{x}}\right)$ was calculated based on river discharge, slope, and velocity (Fischer et al. 1979; McQuivey and Keefer 1974):

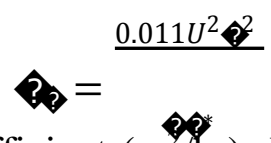

where $E_{x}$ is longitudinal dispersion coefficient $\left(\mathrm{m}^{2} / \mathrm{hr}\right), U$ is the average river velocity $(\mathrm{m} / \mathrm{hr}), B$ is the width of the river $(\mathrm{m}), H$ is the average river depth $(\mathrm{m})$, and $u^{*}$ is the average shear velocity $(\mathrm{m} / \mathrm{hr})$. 
The average shear velocity is calculated by means of equation 10 .

$$
u^{*}=\sqrt{ } g H ?
$$

where $\mathrm{u}^{*}$ is the average shear velocity $(\mathrm{m} / \mathrm{hr}), \mathrm{g}$ is acceleration due to gravity $\left(\mathrm{m}^{2} / \mathrm{hr}\right), \mathrm{H}$ is average river depth $(\mathrm{m})$, and $\mathrm{S}$ is the channel slope (dimensionless).

5. Vertical dispersion of the dissolved LNAPL. Mixing in the vertical direction $\left(\varepsilon_{\mathrm{z}}\right)$ is less significant than longitudinal dispersion. Vertical dispersion is a function of the velocity profile; it was quantified by a simple equation based on average water depth and shear velocity (Fischer et al. 1979):

$$
\varepsilon_{z}=0.067 H u^{*}
$$

where $\varepsilon_{z}$ is the vertical diffusion coefficient $\left(\mathrm{m}^{2} / \mathrm{hr}\right), H$ is average river depth $(\mathrm{m})$, and $u^{*}$ is the average shear velocity $(\mathrm{m} / \mathrm{hr})$.

Buoyancy can be incorporated by decreasing the vertical dispersion effects, but there has been little empirical research to determine how much buoyancy affects dispersion in real streams (Fischer et al. 1979).

6.Lateral dispersion of the dissolved LNAPL. Like vertical dispersion, the lateral dispersion of a chemical is less significant than that of longitudinal dispersion. The rate of dispersion in the lateral direction is calculated by equation 12 .

$$
\varepsilon_{y}=0.6 H u^{*}
$$

where $\varepsilon_{\mathrm{y}}$ is the lateral dispersion coefficient $\left(\mathrm{m}^{2} / \mathrm{hr}\right), \mathrm{H}$ is the average depth of the channel $(\mathrm{m})$, and $\mathrm{u}^{*}$ is the shear velocity $(\mathrm{m} / \mathrm{hr})$. 


\subsection{Methodology}

\subsubsection{Model Geometry}

Five cross sections, one beginning at the location of the Freedom Industries Storage facility, and continuing downstream to the location of the American Water System, were collected by USGS methods. A boat traversed the cross section, recording its GPS location, the depth, and the velocity perpendicular to the cross-section measured at approximately $7 \mathrm{~cm}$ intervals. A longitudinal profile was collected by traveling down the middle of the stream channel and measuring at approximately $1 \mathrm{~m}$ intervals. The slope of the river was estimated by plotting the longitudinal profile on a graph and fitting a linear trend line. The slope of the trend line was assumed to be the slope of the river bed.

A moving average was taken every $2 \mathrm{~m}$ from the high-resolution USGS data in order to create a cross-section to be used in the model (Figure 15). The channel sides were assumed to be sloped, because the USGS information did not include the location of the interface of the bank and water surface. 
$\operatorname{Track}(\mathrm{m})$

a

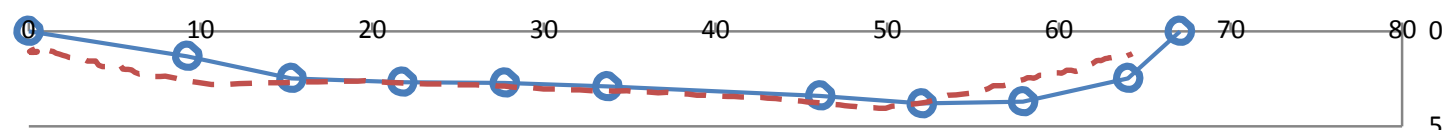

b

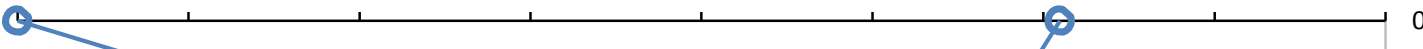

Depth (m)

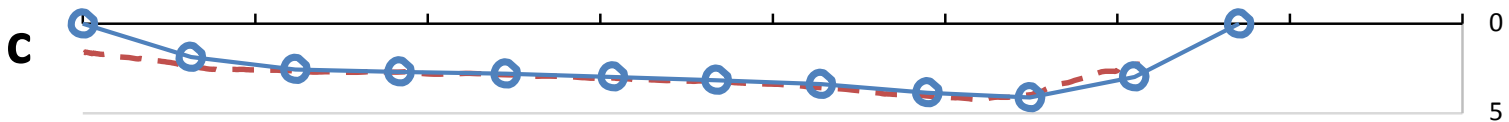

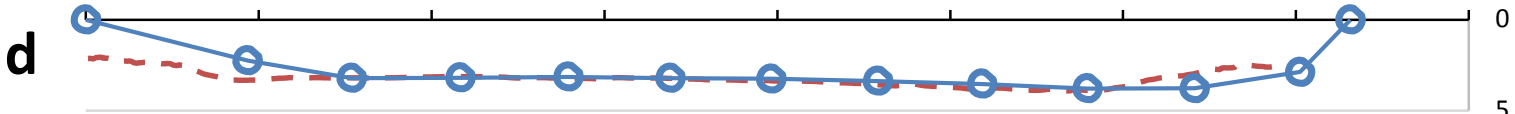

e

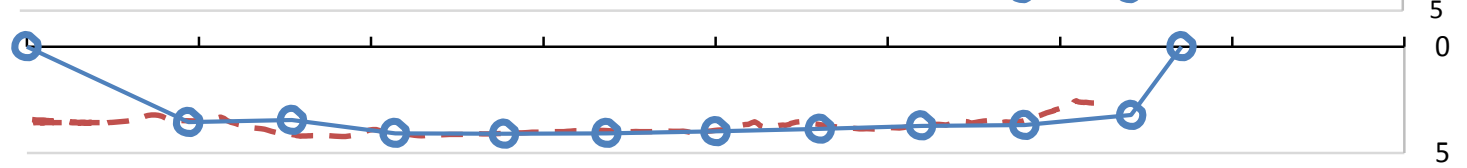

- - - USGS measured depth

- - Model Cross-section

Figure 15 The cross-sections created for the model overlaid the USGS measured depths of the Elk River a) at the spill intake; b) $230 \mathrm{~m}$; c) $1000 \mathrm{~m}$; d) $1730 \mathrm{~m}$; e) $2500 \mathrm{~m}$ at the American Water system intake, approximately.

The coordinates of the cross-section measurements by the USGS were mapped using ArcGIS to determine the distances between the left bank and the right bank for each crosssection The USGS measured depths and the bank distances were used in HEC-RAS XS Interpolation tool to create seventy-three cross-sections from the location of the spill to the water intake facility (Figure 16). 


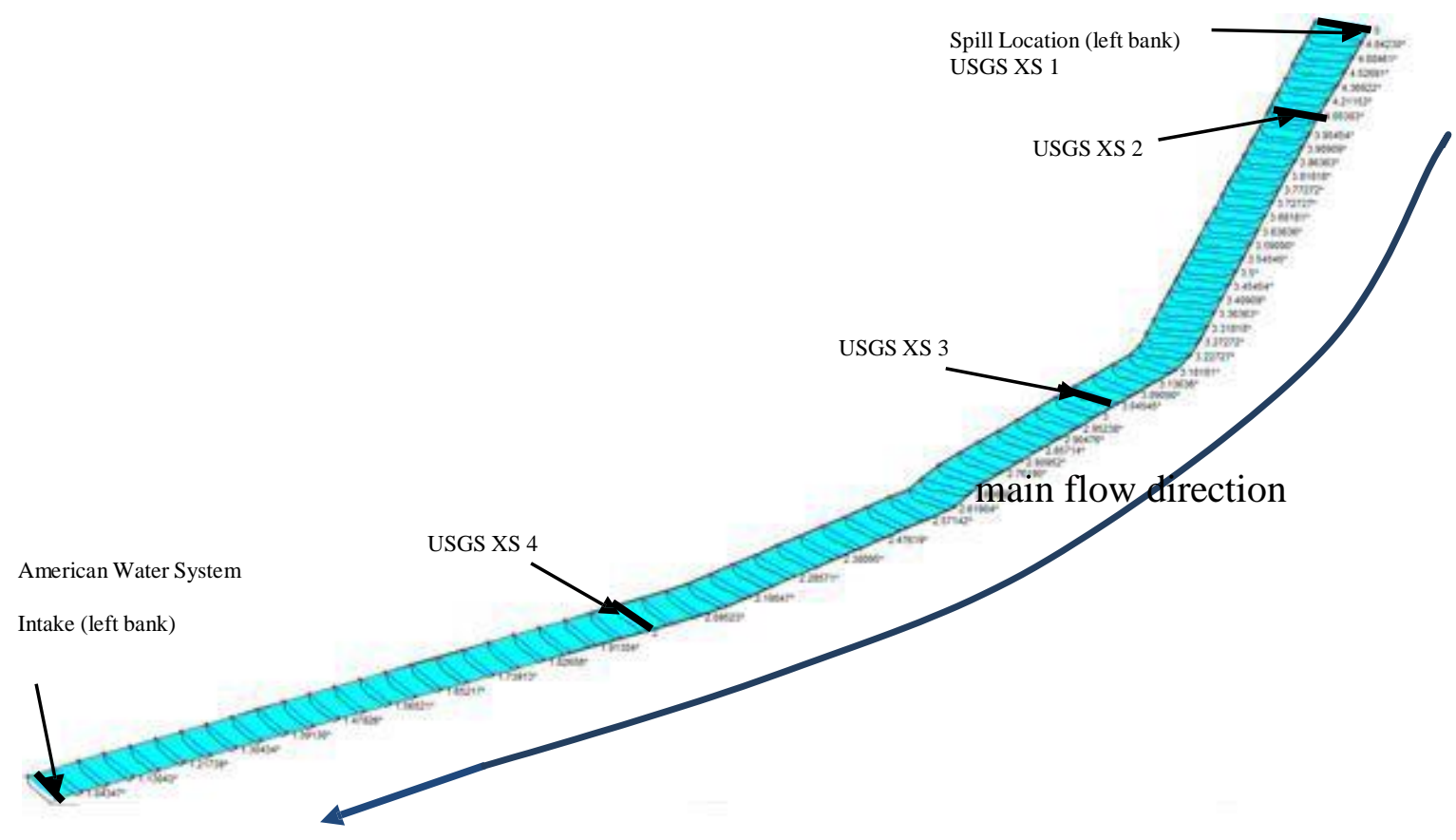

Figure 16 The Elk River geometry as it was used in the three-dimensional model.

\subsubsection{Control volume Approach}

The Elk River has a bank full width that ranges from 60 to $72 \mathrm{~m}$. Fifteen depths per cross-section defined the channel boundaries. The distance between the cross-sections (36 $\mathrm{m})$ were evaluated to be sufficiently small to handle the numerical dispersion and positivity issues that come with numerical finite-difference method. The river was divided into control volumes so that there were twelve sections in the y-direction. The control volume was a trapezoidal prism. The control volumes were divided into $0.5 \mathrm{~m}$ deep sections, so that the contours of the river channel were incorporated into the dispersion calculations.

A function for loading the chemical was applied to the left-most, top cell of the simulation. This position corresponds to the location of Freedom Industries on the river bank. The function included a chemical loading rate of $1,485 \mathrm{~kg} / \mathrm{hr}$ (Boucher 2014). After twenty hours the loading was reduced to represent the time after the spill event. Vertical, longitudinal and 
lateral dispersion were calculated for each control volume based on the flux of each surface of the control volume. Functions for chemical movement, described in Section 3.1.2, were applied to calculate the accumulation and loss of the contaminant from each control volume. There were boundary conditions at every control volume surface that was aligned with a channel wall of the Elk River. The boundary conditions were defined such that there would be no dispersion in these directions. Also, there were boundary conditions so that mass transfer and dissolution would not occur if LNAPL was absent from the control volume.

The variables of the river's dispersion qualities and the chemical properties could be changed for each control volume. The model's output was a matrix of the chemical concentration estimated for each control volume. The matrix was uploaded to a three-dimensional visualization software, Tecplot 10 (Bellevue, WA), to visualize the chemical plume in the river at any given time-step.

\section{Numerical Stability}

Control volumes were used to represent regions of the river in order to minimize computer processing time. This generalization, however, can make the numerical calculations unstable over large time-steps and large $\mathrm{x}$-segments. Therefore the lower range of the dispersion parameter values were limited by the model's geometry, because it affects numerical stability of the model. In this model geometry, the model ran on a 0.012 second time-step to ensure stability. If the time-step was longer, positivity issues would arise because the transport function would calculate a movement of contaminant greater than what is present in the previous time-step, resulting in an oscillation from positive to negative estimations at greater values. In scenarios with less dispersion, described in the next section, positivity issues were avoided by decreasing the length (x-direction) of the control volumes in half. 


\subsubsection{Modeling Scenarios}

\section{Scenarios based on empirical information and other parameters}

There were several parameters that were calculated from empirical methods or from the EPA Estimation Suite. There were some uncertainty in these variables. For instance based on the EPA's Estimation Program Interface Suite, the solubility of MCHM in air is about 2,024 g/ $\mathrm{m}^{3}$, but recent findings by $\mathrm{He}$ et al. (2015) determined the solubility to be $1,518 \mathrm{~g} / \mathrm{m}^{3}$. Lower volatilization is possible because most literature values reflect chemical properties at 20 to $25^{\circ} \mathrm{C}$, when in fact the days before the spill rarely had temperatures above the freezing temperature of water. Freezing temperatures can affect solubility of an organic compound in water to be $50 \%$ to $80 \%$ that of at $25^{\circ} \mathrm{C}$ (Delgado 2007); the solubility in air can be $25 \%$ to $30 \%$ of the solubility at $25^{\circ} \mathrm{C}$ (Görgényi et al. 2002). The lower dispersion scenario addresses observations that empirical calculations are sometimes three times greater than the actual dispersion of a body of water (Fischer et al. 1979).

The parameter values related to dispersion, loading rate, and chemical properties were adjusted in three scenarios: one based on empirical observation, one with lower volatilization phenomena, and one with less dispersion (Table 21). The minimum parameter values for the lower dispersion and lower volatilization scenario were combined in a fourth simulation was called a "conservative" simulation. For each of these scenarios the MCHM loading rate was $1,485 \mathrm{~kg} / \mathrm{hr}$ and lasted for twenty hours. Forty hours were simulated to demonstrate the migration of the plume downstream from the study area. 
Table 18 Parameter values for 1) the empirical observation, 2) the lower volatilization, 3) the less dispersion, and 4) conservative simulations.

\begin{tabular}{|c|c|c|c|c|}
\hline & $\begin{array}{l}\text { Empirical } \\
\text { Observations }\end{array}$ & $\begin{array}{l}\text { Lower } \\
\text { Volatilization }\end{array}$ & Less Dispersion & Conservative \\
\hline $\begin{array}{l}C_{g}, \\
C_{s}\end{array}$ & $\begin{array}{l}1,518 \mathrm{~g} / \mathrm{m}^{3}, 1,585 \mathrm{~g} / \mathrm{m}^{3} \\
\text { (He et al. 2015) }\end{array}$ & $\begin{array}{l}375 \mathrm{~g} / \mathrm{m}^{3} \text { (Görgenyi } \\
\text { et al. 2002)., 1,585 } \\
\mathrm{g} / \mathrm{m}^{3} \text { (Delgado 2007; } \\
\text { He et al. 2015) }\end{array}$ & $\begin{array}{l}1,518 \mathrm{~g} / \mathrm{m}^{3}, 1,585 \\
\mathrm{~g} / \mathrm{m}^{3} \text { (He et al. 2015) }\end{array}$ & $\begin{array}{l}375 \mathrm{~g} / \mathrm{m}^{3} \text { (Görgenyi et } \\
\text { al. 2002)., } 1,585 \mathrm{~g} / \mathrm{m}^{3} \\
\text { (Delgado 2007; He et } \\
\text { al. 2015) }\end{array}$ \\
\hline$k_{d}$ & $\begin{array}{l}0.65 \mathrm{~kg} / \mathrm{hr} \text { (Southworth } \\
1979 \text { ) }\end{array}$ & $0 \mathrm{~kg} / \mathrm{hr}$ & $\begin{array}{l}0.65 \mathrm{~kg} / \mathrm{hr} \\
\text { (Southworth 1979) }\end{array}$ & $0 \mathrm{~kg} / \mathrm{hr}$ \\
\hline $\begin{array}{l}E_{x} \\
\varepsilon_{y}, \varepsilon_{z}\end{array}$ & $\begin{array}{l}11,666 \mathrm{~m}^{2} / \mathrm{hr}, 766 \\
\mathrm{~m}^{2} / \mathrm{hr}, 85 \mathrm{~m}^{2} / \mathrm{hr} \\
\text { (Fischer et al. 1979) }\end{array}$ & $\begin{array}{l}11,666 \mathrm{~m}^{2} / \mathrm{hr}, 766 \\
\mathrm{~m}^{2} / \mathrm{hr}, 85 \mathrm{~m}^{2} / \mathrm{hr} \\
\text { (Fischer et al. 1979) }\end{array}$ & $\begin{array}{l}5,400 \mathrm{~m}^{2} / \mathrm{hr}^{*}, 400 \\
\mathrm{~m}^{2} / \mathrm{hr}, 50 \mathrm{~m}^{2} / \mathrm{hr} \text {. } \\
\text { (Fischer et al. 1979) }\end{array}$ & $\begin{array}{l}5,400 \mathrm{~m}^{2} / \mathrm{hr}^{*}, 400 \\
\mathrm{~m}^{2} / \mathrm{hr}, 50 \mathrm{~m}^{2} / \mathrm{hr} . \\
\text { (Fischer et al. 1979) }\end{array}$ \\
\hline
\end{tabular}

* Control volumes were made half as long in the $\mathrm{x}$-direction to allow for numerical stability at lower dispersion rates

\section{Scenarios with at different chemical loading rates}

Also calculated were three simulations based on empirical observations using three different loading rates: 1) twenty hours of chemical loading at a rate of $1,485 \mathrm{~kg} / \mathrm{hr}$; 2) twenty hours of loading at $4,455 \mathrm{~kg} / \mathrm{hr}$; 3) three hours of loading at $9,900 \mathrm{~kg} / \mathrm{hr}$. The first simulation is based on what was reported by Freedom Industries after the Elk River Spill; the second is based on the maximum volume of the above ground storage tank, or the worst case of loading based on Freedom Industries' storage design; the third simulation is based on an escalated loading scenario where the volume of the chemical was the same as the Elk River spill, but loaded into the body of water more rapidly. 


\subsection{Results}

The transport mechanisms in the Elk River reached a quasi-steady-state from the spill location to the American Water Systems' intake. This state occurred when the rate at which the chemical had entered the control volume was equal to the amount leaving. This would take about 8 hours.

\section{Empirical, Dispersion and Volatilization scenarios of contaminant transport}

There were three scenarios tested: one simulation based on empirical and published values, one with less volatilization, and one with decreased hydrologic dispersion (Table 21). The results from empirical simulation (Figure 17) generated a concentration at the intake with a magnitude of 2 orders less than the $3.5 \mathrm{ppm}$ measured at the American Water influence twelve hours after the spill (Weidhaas et al. 2015). This indicates that the model is not accurate for simulating the plume distribution. The dispersion phenomena of the river mixing and chemical volatilization are too great, diluting the MCHM concentration significantly within the first $500 \mathrm{~m}$ of river travel.

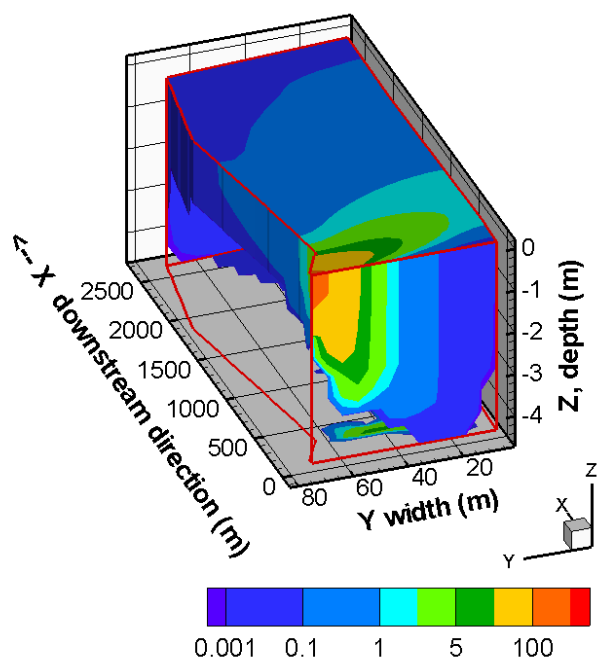

The spill is located at $(0,80,0) \mathrm{m}$.

The American Water System intake is on the $\mathrm{x}=2500 \mathrm{~m}$ cross section.

Figure 17 Results from the empirical model simulation at 8 hours after the spill was initiated. 
For the lower volatilization simulation, the quasi-steady-state was also reached by the time of 8 hours. The simulation shows that the peak concentration at the intake was approximately $1.5 \mathrm{ppm}$ (Figure 18). A concentration greater than $1 \mathrm{ppm}$ persisted for a greater volume of the river body than in the empirical model. The chemical persists in higher concentration because there is less chemical lost to the gaseous phase and the mass transfer is less rapid than in the empirical estimation. $\mathrm{C}_{\mathrm{s}}$ is not a limiting factor, because the chemical is very soluble, but in less soluble chemicals a low $\mathrm{C}_{\mathrm{s}}$ may keep it in an undissolved state.

For the simulation with less dispersion, the quasi-steady-state was reached similarly to the previous two simulations, at 8 hours. The peak concentration at the intake was near $1.5 \mathrm{ppm}$ and the river body had a concentration of greater than $2 \mathrm{ppm}$ across the volume of the river body. The right side of the river, directly across the spill location, had near-zero parts per million, less than the previous simulations. This occurred because the y-direction dispersion coefficient was less than the empirical simulation. In the lower hydrologic dispersion scenarios, it is shown that it would be less likely to detect spills from the opposite banks of the spill location. The influence of dispersion in the y-direction becomes less evident as the contaminant travels downstream as the chemical becomes more distributed. 


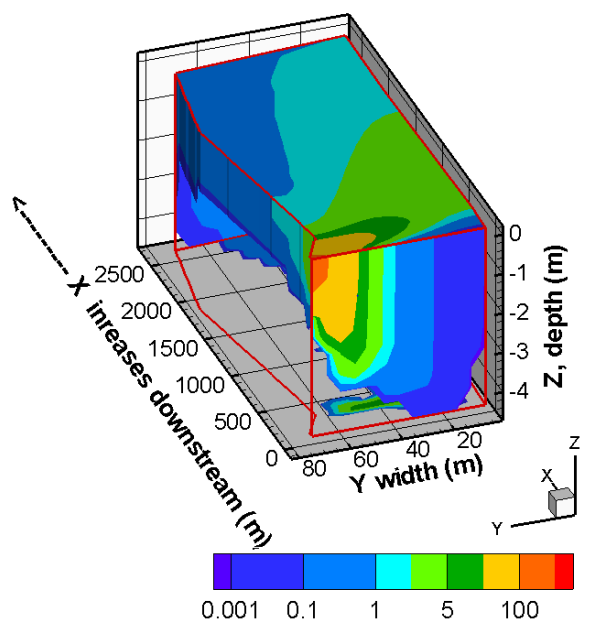

The spill is located at $(0,80,0) \mathrm{m}$.

The American Water System intake is on the $\mathrm{x}=2500 \mathrm{~m}$ cross section.

Figure 18 Results from the less volatilization simulation at quasi-steady state at 8 hours.

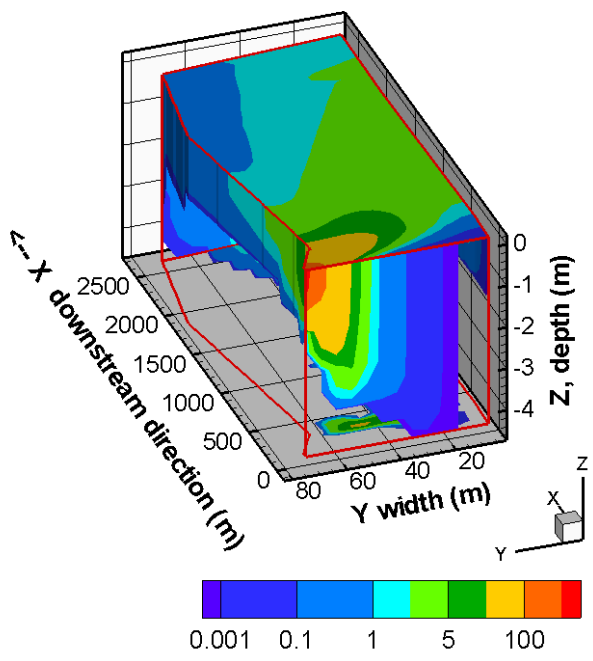

The spill is located at $(0,80,0) \mathrm{m}$.

The American Water System intake is on the $\mathrm{x}=2500 \mathrm{~m}$ cross section.

Figure 19 Results from the decreased dispersion simulation at the quasi-steady state at 8 hours.

The conservative simulation had a peak concentration at the intake of $26 \mathrm{ppm}$. The magnitude of increase was due to the combined lower dispersion and the lower volatilization (Figure 20). This was most like observations at the day of the event. The bulk of the contaminant was concentrated on the left river bank. 


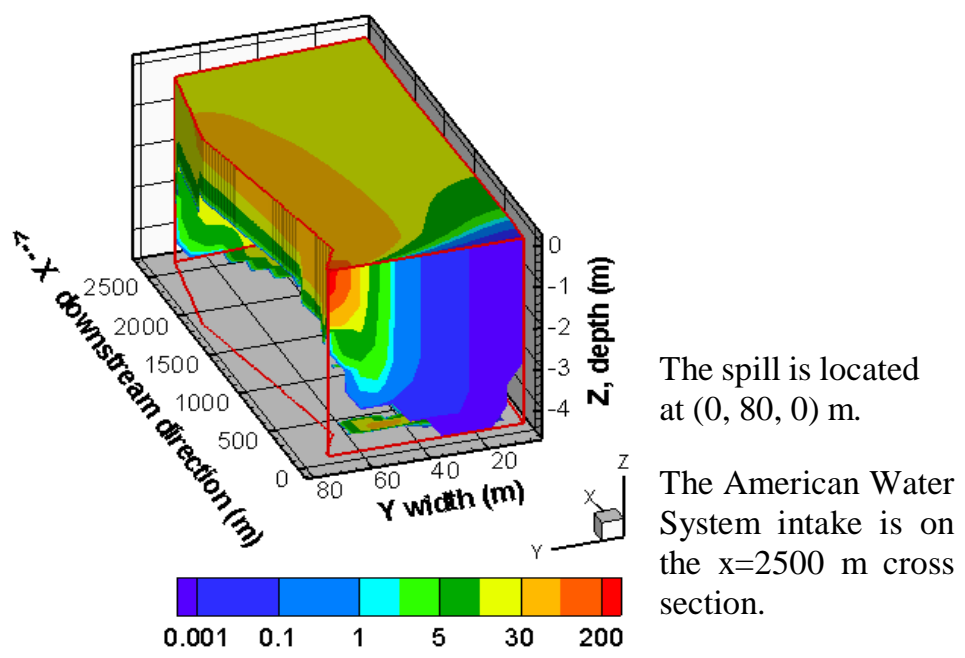

Figure 20 the results of the conservative simulation at 8 hours.

The lower dispersion and mass transfer scenarios are probably more accurate because it was $0^{\circ} \mathrm{C}$ in the area three days prior to the spill. Lower temperatures impede dispersion. The Elk River is a wide river without rocky features, so the mixing may be less than what was estimated by empirical methods.

There are implications on chemical dispersion on predicting travel times of the contaminant. Though it does not change the time of arrival for the leading edge or the residence time of the plume, the contaminant is more persistent at higher concentrations. The plume progression was plotted in aerial view for all three simulations (Figure 21). If the concentration of $0.5 \mathrm{ppm}$ was used as the threshold value, the chemical was volatilized to less than the threshold value before reaching the intake cross-section in the empirical simulation. It took 6 hours for this amount of concentration to progress the $2500 \mathrm{~m}$ downstream. For the less volatilization simulation, the threshold value reached the intake at 4 hours.

The plume progressed to the right side of the channel within about $250 \mathrm{~m}$ in all simulations. As most evident in the empirical simulation (Figure 21i), the right side of the bank 
had more rapid progression of the plume than on the left side of the bank. Dispersion influenced the shape of the plume as it expands laterally across the river surface.
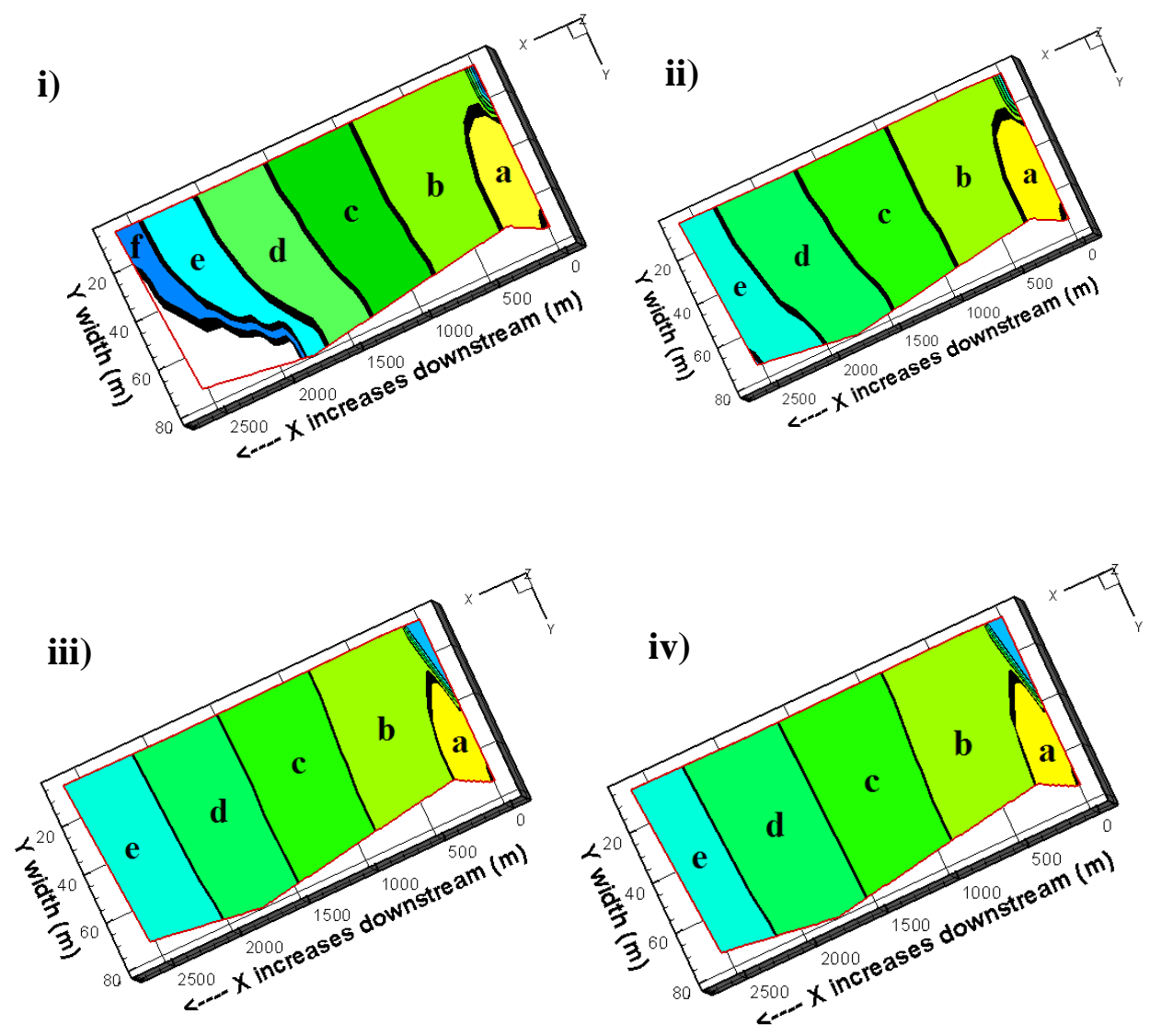

Figure 21 The leading edge of the $0.05 \mathrm{ppm}$ plume over time for the (i) empirical simulation, (ii) less volatilization simulation, (iii) less dispersion, and (iv) combined less volatilization and less dispersion, at a) 10 minutes, b) 1 hour, c) 2 hours, d) 3 hours e) 4 hours, and f) 6 hours.

\section{Effect of loading rates on chemical concentration at the American Water Systems' intake}

The different loading scenarios represent the distribution of the contaminant under the empirical model. For scenarios shown in Figure 22a and c, the shape of the contaminant plume at the face of the z-y plane are of similar shape, but the contaminant plumes have different magnitudes. These scenarios are of the same volume of chemical at different loading rate. 
Figure $22 \mathrm{~b}$ represented what would have been the maximum volume of chemical that could have been stored in the failed above ground storage tank: 30,000 gallons. The spill duration was the same as the empirically calculated simulation of the Elk River spill (Figure 22a, Boucher 2014). The magnitude of the concentration at the intake was calculated to be greater than previous simulations, and the contaminant was more evenly distributed across the entire cross-section.
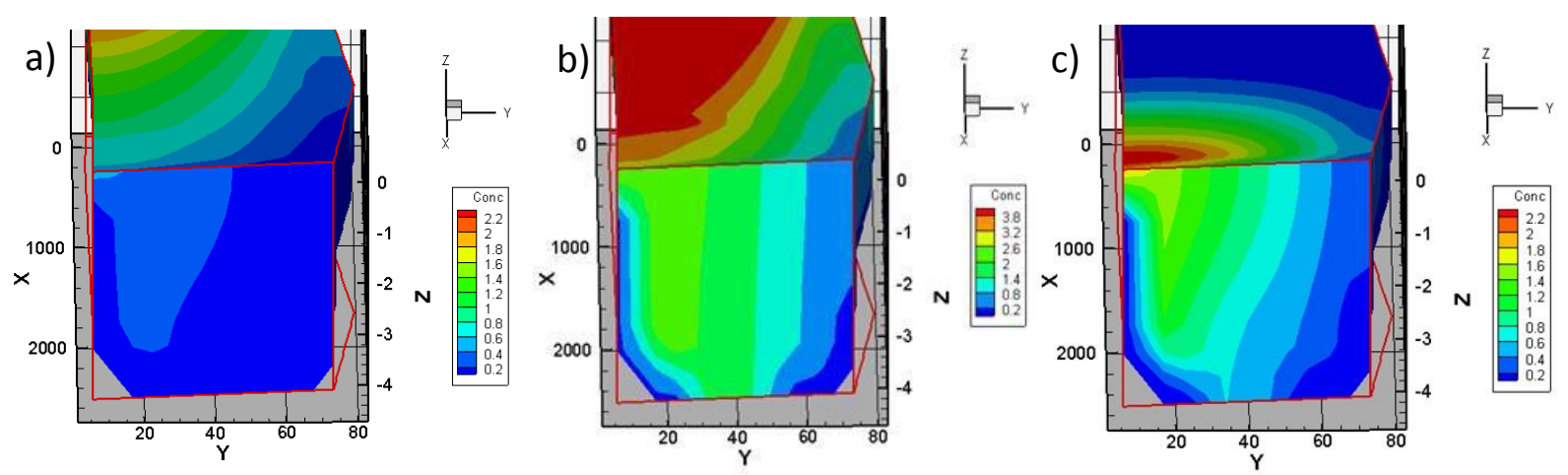

Coordinates are in meters, looking upstream of main river flow

Figure 22 Cross-sections at the American Water System intake, a) 20 hours of loading at a rate of $1485 \mathrm{~kg} / \mathrm{hr}$ at quasi-steady-state; b) 20 hours of loading at a rate of $4455 \mathrm{~kg} / \mathrm{hr}$ at quasi-steadystate; c) 3 hours of loading at $9900 \mathrm{~kg} / \mathrm{hr}$ at the peak of the chemical plume.

\subsection{Discussion}

The aim of the hydrologic model of the Elk River Spill was to determine, with limited information, if parameters could be optimized to simulate the spill distribution as it occurred on January 9, 2014. Further simulations were conducted to determine applications of this three dimensional information. It was found when river geometry is held constant, the rate of hydrologic dispersion and chemical mass transfer rate has more influence on MCHM distribution than the solubility of the chemical in gaseous and aqueous phases (Figure 23). The mass transfer due to aqueous solubility in this model was not an influential parameter because the loading rate did not create saturation conditions. Chemicals with lower solubility may be more greatly affected by this parameter; MCHM is appreciable soluble in water. 


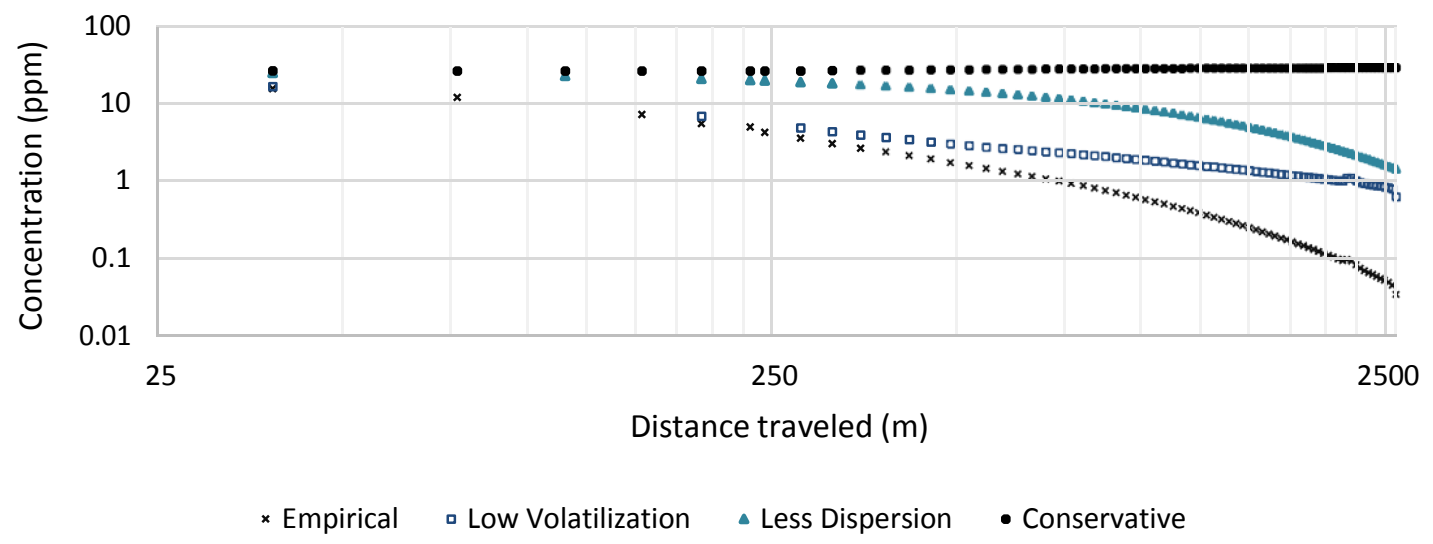

Figure 23 Simulated concentration, averaged across the cross-section of the floating MCHM at the surface of the Elk River surface after 8 hours, from the near the spill location to the American Water Systems intake $(x=2500$ m).

The empirical simulation was less than field observations by a factor of 70 . The empirical estimations for dispersion were probably incorrect approximations because of the very low temperatures at the time of the spill. The temperatures had not exceeded $0^{\circ} \mathrm{C}$ for three days prior to the spill event. The lower temperatures lead to less molecular energy, decreasing the rate of dispersion and mixing. In the model, decreasing either the mass transfer rate or the hydrologic dispersion increased the intake concentration by a magnitude of 200 , with the bulk of the plume accumulating on the right side of the channel, opposite the intake. These simulations still underestimated concentrations at the intake by a factor of 3 . The conservative simulation, where dispersion and mass transfer parameters were decreased, had results that exceeded American Water System measurements in the days after the spill. This is still a reasonable estimate as during the spill occurrence it was likely that concentrations were higher than after the plume had passed. The modeled peak concentration was $26 \mathrm{ppm}$ for the conservative simulation, a magnitude of 500 greater than the empirical estimation. The plume had a greater distribution to the left side of the channel, which concurs with reports by eyewitnesses. 
If the empirical model had been applied to estimate the risk from the Elk River Spill event, the model would have underestimated both the travel time of a threshold concentration of $50 \mathrm{ppb}$ and the contaminant concentration at the intake. It was found that lower dispersion rates have more rapid travel times, because the chemical persists at a higher concentration. The conservative model, where both hydrologic dispersion and mass transfer rate are affected by temperature, should be used when the environmental conditions are colder than the temperature used to determine the chemical properties reported in datasheets.

The parameters used in this model can vary from river body and chemical type, but the parameters can be evaluated in controlled situations. Actual hydrologic dispersion should be estimated in areas of concern, i.e. areas near water intake facilities or other source water protection areas, both at different discharge rates and across the range of temperatures typical for a region. Volatilization and adsorption rates are unique to each chemical and may vary due to environmental effects of temperature as well as wind and water velocity. These uncertainties can be investigated with laboratory testing to evaluate volatilization as affected by wind and temperature.

A three-dimensional model provides descriptive information about the spill distribution near the spill location. Because the Elk River was not nearly as deep as it is wide, the vertical dispersion was not very noticeable within a few hundred meters from the spill location. The model did demonstrate that different loading rates affect the distribution of the chemical laterally in the cross section $2500 \mathrm{~m}$ away from the spill location. For modelling the best placement for sensing technologies near possible spill locations of a wide, shallow water body, it would be beneficial to use a 2-dimensional hydrologic model. This is because the mixing in the third dimension is not significant, yet the lateral and longitudinal directions have varied chemical 
distribution. Hydraulic models may be more appropriate if there are waterbody features that impede full mixing, such as rough surfaces or hydraulic features (i.e. waterfalls, dams). If the water body is very deep, then the third dimension may be considered again. Using fewer dimensions in a model cuts down the computation time, and which gives greater versatility in for running various simulations. When developing regional or watershed models, the longitudinal dimension would be most important because the mixing in the vertical and lateral directions become less significant as contaminants travel long distances. Confluences of streams may be considered with higher resolution (i.e. 2-dimensions) because as shown in the less hydrologically dispersive models, the opposite bank of a point-source spill event may not be affected by the contaminant plume.

The model can be expanded upon to simulated parameter effects of less volatile or less soluble chemicals, and to determine differences in the chemical distribution. If the finite element difference was further developed to incorporate chemical reactions, adsorption and multiple contaminant types, the model could be applied to a variety of tools, including contaminant fate and active treatment methods.

\subsection{Conclusion}

In the various simulations of the Elk River Spill model, it was shown that the hydrologic dispersion and chemical properties had a compounding effect on the peak concentration. The persistence of the chemical causes for lower travel times than what would be estimated using empirical information. It is necessary to consider temperature when incorporating chemical diffusion in a mass transfer model. Considering temperature was important in this model because the weather at the time of the spill was $25^{\circ} \mathrm{C}$ less than typical laboratory analysis conditions. Also, the empirical methods used do not incorporate the freezing temperatures as they affect 
dispersion. The conservative model where dispersion and mass transfer parameters were reduced showed much more reasonable peak concentrations and chemical distribution than the empirical simulation. 


\subsection{Thesis Conclusion}

A combination of the instrument assessment and the three-dimensional contaminant transport model can be used in decision making in the placement of detection technology. Different chemical loading scenarios and chemical properties can be simulated, and technology can be placed based on its detection threshold. If used on a regional scale, areas of greater risk can be identified, and early warning system tools can be placed based to detect the most probable or riskiest surface water pollution scenarios. Regional or city planners may determine, with greater certainty, the risk of industrial operations involving aqueous chemicals near rivers upstream of public works facilities.

The Elk River Spill was an event that brought the vulnerability of water quality to the public attention. The magnitude of distress experienced by the people of Charleston, WV justifies the development of early warning systems in any public water supply system to prevent disaster. The information needed to develop models and early warning systems are shown to be readily available: some about the location of chemical risks, some about the chemical properties that influence dispersion, and some about hydrologic factors that determine the speed of chemical distribution. The combination of this information can be applied to the development of monitoring systems, and may contribute to better understanding of the anthropogenic effects on water quality. 


\subsection{References}

Allan, I., Vrana, B., Greenwood, R., Mills, G., Roig, B., and Gonzalez, C. (2006). "A "toolbox" for biological and chemical monitoring requirements for the European Union's Water Framework Directive." Talanta, 69, 302-322.

American Water Resources Association (AWRA) (1998). "Means to Improving Water-Quality Monitoring in the United States".

<http://wi.water.usgs.gov/lmmcc/references/awrapape.html> (May 5, 2015)

Bedient, P.B., and Huber, W.C. (2001). Hydrology and Floodplain Analysis, Pearson, Camden, New Jersey.

Bharti, N. and Katyal, D. (2011). "Water quality indices used for surface water vulnerability assessment." International J. of Environ. Sci., 2(1).

Boucher, D. (2014). "Expert says tank leaked for at least 20 hours" Charleston Daily Mail, <http://www.charlestondailymail.com/News/Kanawha/201401280181> (Feb 17, 2015).

Brantley, S., Yoxtheimer, D., Arjmand, S., Grieve, P., Vidic, R., Pollak, J., Llewellyn, G., Abad, J., and Simon, C. (2014). "Water Resource impacts during unconventional shale gas development: The Pennsylvania experience.” International J. of Coal Geol., 126, 140156.

Brown, L. and Barnwell, T. (1987). "The enhanced stream water quality models QUAL2E and QUAL2E-UNCAS: documentation and user manual.” US EPA, Athens, GA.

Caissie, D., Pollock, T. and Cunjak, R. (1996). "Variation in stream water chemistry and hydrograph separation in a small drainage basin." J. of Hydro., 178, 137-157.

Caenn, R., Darley H. and Gray, G. (2011). Composition and Properties of Drilling and Completion Fluids, Gulf Professional Publishing, Oxford, UK.

Christie, R., Gross, A., and Fortin, R. (1990). Process for coal flotation using 4-methyl cyclohexane methanol frothers, Nalco Chemical Company, Naperville, Illinois.

Cooper, W.J. (2014). "Responding to Crisis: The West Virginia Chemical Spill.” Environ. Sci. and Tech., 48(6), 3095.

Davies, S. and Tsomides, L. (2002). "Methods for biological sampling and analysis of Maine's rivers and Streams." Maine Department of Environmental Protection, Augusta ME.

Delgado, J. (2007). "Molecular Diffusion Coefficients of Organic Compounds in Water at Different Temperatures.” J. of Phase Equilibria and Diffusion, 28(5), 427-432. 
DiToro, D., Fitzpatrick, J. and Thomann, R. (1983). "Documentation for the Water Quality Analysis Simulation Program (WASP) and Model Verification Program (MVP).”US EPA, Grosse Ile, MI.

Dixon, W. and Chiswell, B. (1996). "Review of Aquatic Monitoring Program Design.” Water Research, 30(9), 1935-1948.

Downstream Strategies (2013). "Water Resource Reporting and Water Footprint from Marcellus Shale Development in West Virginia and Pennsylvania." Earthworks Oil and Gas Accountability Project, Morgantown, WV.

Emerson, D.G., Vecchia, A. V., and Dahl, A.L. (2005). "Evaluation of Drainage-Area Ratio Method Used to Estimate Streamflow for the Red River of the North Basin, North Dakota and Minnesota." Scientific Investigations Report 2005-5017, US Geological Survey, Reston, Virginia.

Fischer, H., List, E., Koh, R., Imberger, J., and Brooks, N. (1979). Mixing in Inland and Coastal Waters, Academic Press, San Diego, CA.

Görgẻnyi, M., Dewulf, J., and Langenhove, H. (2002). “Temperature dependence of Henry's law constant in an extended temperature range." Chemosphere, 48, 757-762.

Grayman, W. and Males, R. (2002) "Risk-based modeling of early warning systems for pollution accidents." Water Sci. and Tech., 46(3), 41-49.

Groundwater Protection Council and Interstate Oil \& Gas Compact Commission (GWPC). (2014). "Chemical Use in Hydraulic Fracturing". FracFocus, <http://www.Fracfocus.org/chemical-use> (Sept 25, 2014)

Guasch, H., Armengol, J., Marti, E. and Sabater, S. (1998). "Diurnal variation in dissolved oxygen and carbon dioxide in two low-order streams." Water Research, 32(4), 10671074.

Guningham, N., Kagan, R., and Thornton, D. (2006). "Socieal License and Environmental Protection: Why Businesses Go Beyond Compliance." Law and Social Inquiry, 29(2), 307-341.

Haluszczak, L., Rose, A., and Kump, L. (2013). "Geochemical evaluation of flow back brine from Marcellus gas wells in Pennsylvania, USA.” Applied Geochemistry, 28, 55-61.

Hammack, R., Zorn, E., Harbert, W. Capo, R., Sharma, S. and Siriwardane, H. (2013). “An Evaluation of Zonal Isolation After Hydraulic Fracturing; Results from Horizontal Marcellus Shale Gs Well's at NETL's Greene County Test Site in Southwestern Pennyslvania." Proc., SPE Eastern Regional Meeting, Society of Petroleum Engineers, Pittsburgh, PA.

Haney, P. and Schmidt, J. (1958) "Representative Sampling and Analytical Methods in Stream Studies" Sewage and Industrial Wastes, 30(6), 812-820. 
He, Y., Noble, A., and Ziemkiewicz, P. (2015). "Investigation of MCHM transport mechanisms and fate: Implications for coal beneficiation." Chemosphere, (127), 158-163.

Henry, W. (1803). "Experiments on the Quantity of Gases Absorbed by Water, at different temperatures and under different pressures." Philosophical Trnsactions of the Royal Society, 93, 29-274.

Hirsch, R., Alley, W., and Wilber, W., (1988). “Concepts for a National Water-Quality Assessment Program.” Circular 1021, USGS, Reston, VA.

House, M. and Newsome, D. (1989) Advances in Water Pollution Control: Urban Discharges and Receiving Water Quality Impacts, Pergamon Press, New York, New York.

Jobson, H.E. (1996). "Prediction of Travel time and Longitudinal Dispersion in Rivers and Streams." USGS, Reston, VA

Kelly, M. (1998). "Use of the Trophic Diatom Index to Monitor Eutrophication in Rivers." Water Research, 32(1), 236-242.

King, G. (2012) "Hydraulic Fracturing 101: What every representative, environmentalist, regulator, reporter, investor, university researcher, neighbor and engineer should know about estimating frac risk and improving frac performance in unconventional gas and oil wells." Proc., Society of Petroleum Engineers Hydraulic Fracturing Technology Conference Woodlands, Texas.

Lide, D. (1994). CRC handbook of chemistry and physics, CRC Press Inc., Boca Raton, FL.

Lutz, B., Lewis, A. and Doyle, M. (2013). "Generation, transport, and disposal of wastewater associated with Marcellus Shale gas development." Water Resources Research, 49, 1-10

McQuivey, R. and Keefer, T. (1974). "Simple Method for Predicting Dispersion in Streams." J. of the Environ. Eng. Division, ASCE, 10708(EE4), 997-1011

Memmot, M. (2014) "Chemical Leak causes Water Emergency in West Virginia; Plant shut down." NPR, <http://www.npr.org/blogs/thetwo-way/2014/01/10/261282459/chemicalleak-causes-water-emergency-in-west-virginia> (May 9, 2015)

Mulholland, P., Houser, J. and Maloney, K. (2005). "Stream diurnal dissolved oxygen profiles as indicators of in-stream metabolism and disturbance effects: Fort Benning as a case study." Ecological Indicators. 5(3), 243-252.

National Academy of Sciences, Committee on National Statistics, National Research Council (1977). "A Report to the U.S. Environmental Protection Agency from the Study Group on Environmental Monitoring." National Academy of Sciences, Washington, DC.

National Energy Technology Laboratory (NETL), (2009). "Federal and State Regulations for Produced Water Management”. 
$<$ http://www.netl.doe.gov/research/coal/crosscutting/pwmis/fed-state-regulations $>$. (June 11, 2015)

Paerl, H., Dyble, J., Pinkney, J., Valdes, L., Millie, D., Moisander, P., Morris, J., Bendis, B., and Piehler, M. (2004). Estuarine Indicators, CRC Press, Boca Raton, FL.

Peakall, D. (1994) “The role of biomarkers in environmental assessment.” Ecotoxicology, 3(3), 157

Pellerin, B. and Bergamaschi, B. (2014). "Optical Sensors for Water Quality." Lakeline, USGS, Denver, CO.

Pennsylvania Department of Environmental Protection (PA DEP). "Oil and Gas Compliance Report." <http://www.depreportingservices.state.pa.us/ReportServer/Pages/ReportViewer.aspx?/O il_Gas/OG_Compliance> (Sept 25, 2014)

Rodriguez-Mozaz, S. Lopez de Alda, M., Marco, M., Barcelo, D. (2004) "Biosensors for environmental monitoring A global perspective.” Talanta, 65, 291-297.

Sanchez, E., Colmenarejo, M., Vicente, J., Rubio, A., Garcia, M., Travieso, L. and Borja, R. (2007). "Use of the water quality index and dissolved ox ygen deficit as indicators of watershed pollution." Ecological Indicators, 7(2), 315-328.

Sanders, T. and Ward, R. (1979). "Factors to Consider in the Design of a Water Quality Monitoring Network." Proc., Oil Shale Symposium: Sampling Analysis and Quality Assurance, IndusTrial Environmental Research Laboratory, Cincinnati, OH, 343-346.

Sawyer, A., Cardenas, M., Bomar, A., and Mackey, M. (2009). "Impact of dam operations on hyporheic exchange in the riparian zone of a regulated river." Hydrological Processes. Wiley Interscience, http://www.interscience.wiley.com (January 1, 2015).

Smith, D. and McBride, G. (1990). "New Zealand's National Water Quality Monitoring Network - Design and First Year's Operation". Water Resources Bulletin, American Water Resources Association, 26(5), 768-775

Soeder, D, Sharma, S., Pekney, N., Hopkinson, L., Dilmore, R., Kutchko, B., Stewart, B., Carter, K., Hkala, A., and Capo, R. (2013). "An approach for assessing engineering risk from shale gas wells in the United States." International Journal of Coal Geology, 126, 4-19.

Southworth, G. (1979). "The role of volatilization in removing polycyclic aromatic hydrocarbons from aquatic environments". Bull Environ. Contaminant Toxicology, 21(4-5), 507-14.

Strager, M. (2012). "Tools for Watershed Planning - Development of a Statewide Source Water Protection System (SWPS)" Water Resources Management and Modeling. Intech. < http://cdn.intechopen.com/pdfs-wm/32907.pdf> (January 1, 2014) 
Stednick, J. and Roig, L. (1989). "Kalman filter calculation of sampling frequency when determining annual mean solute concentrations." J. of the American Water Resources Assoc., 25(3), 675-683.

Strobl, R. and Robillard, P. (2008). "Network design for water quality monitoring of surface freshwaters: A review." J. of Environ. Management, 87(4), 639-648.

Strobl, R., Robillard, P., Shannon, R., Day, R. and McDonnell, A. (2006) “A water quality monitoring network design methodology for the selection of critical sampling points: Part 1.” Environ. Monitoring Assessment, 112(1-3), 137-58.

Susquehanna River Basin Commission (SRBC) (2014). "Remote Water Quality Monitoring Network, Real-time Data and Maps." <http://mdw.srbc.net/remotewaterquality/> (Sept $25,2014)$

Susquehanna River Basin Commission (2013). "Comprehensive Plan for the Water Resources of the Susquehanna River Basin". <http://www.srbc.net/planning/ComprehensivePlan6_2014woAppendices.pdf> (May 7, 2015)

Tchobanoglous, G., Burton, F., Stensel, H. (1991). Wastewater Eng. Treatment and Reuse, Metcalf \& Eddy Inc., Wakefield, MA.

Teillet, P., Gauthier, R., Chicagov, A., and Fedosejevs, G. (2002). “Towards integrated Earth sensing: advanced technologies for in-stream sensing in the context of Earth Observation." Canadian Journal of Remote Sensing, 28, 713-718.

Telci, I., Nam, K., Guan, J. and Aral, M. (2009). "Optimal water quality monitoring network design for river systems.” J. of Environ. Management, 90(10), 2987-2998.

Turner, J. and Woodham, W. (1980). "Evaluation of remote hydrologic data-acquisition systems, west central Florida." Water-Resources Investigations Report, USGS, Chantilly, VA.

United Nations Educational, Scientific and Cultural Organization (UNESCO) (1996). "Water Quality Assessments - A Guide to Use of Biota, Sediments and Water in Environmental Monitoring - Second Edition” E\&FN Spon, University Press, Cambridge.

US Department of Energy (US DOE) (2009). "Modern shale gas development in the United States: A primer." US DOE, Washington, D.C.

US Environmental Protection Agency (USEPA), (2015a). "Methods, Models, Tools, and Databases for Water Research." Water Research, <http://www2.epa.gov/waterresearch/methods-models-tools-and-databases-water-research> (March 6, 2015).

USEPA (2015a). "Pollution Prevention and Toxics". <http://www.epa.gov/oppt/> (June 16, 2015). 
USEPA (2015b). "5.3 Temperature”, "5.4: pH”, "5.5 Turbidity", "5.9 Conductivity”. Water: Monitoring and Assessment. 〈http://water.epa.gov/type/rsl/monitoring/vms54.cfm> (April 9, 2015).

USEPA (2012a). "Water Quality Standards History". <http://water.epa.gov/scitech/swguidance/standards/history.cfm> (May 5, 2015).

US EPA (2012b). "Estimation Program Interface (EPI) Suite." Exposure Assessment Tools and Models, <http://www.epa.gov/oppt/exposure/pubs/episuite.htm> (March 6, 2015).

USEPA (2006). "Overview of Watershed Monitoring." Watershed Academy, <http://cfpub.epa.gov/watertrain/pdf/modules/monitoring.pdf > (May 5, 2015)

USEPA (2003). "Integrated Monitoring Design for Comprehensive Assessment and Identification of Impaired Waters Part B" Chapter 10, <http://water.epa.gov/type/watersheds/monitoring/upload/2003_07_02_monitoring_calm _calm_ch10.pdf> (April 9, 2015).

USEPA (1999). "Protecting Sources of Drinking Water Select Case Studies in Watershed Management." Office of Water, EPA, Washington, D.C.

US Geological Survey (USGS) (2015). "USGS Current Water Data for the Nation" National Water Information System: Web Interface. <http://waterdata.usgs.gov/nwis/rt> (May 8, 2015)

Vidic, R., Brantley, S., Vandenbossche, J. Yoktheimer, D., and Abad, J. (2013) "Impact of Shale Gas Development on Regional Water Quality." Science 340, 1-9.

Ward, R., Loftis, J., and McBride, G. (1990). Design of Water Quality Monitoring Systems. Van Nostrand Reinhold, New York, New York.

Watershed Council (2015). "Water Quality Monitoring Data Parameters." <http://www.watershedcouncil.org/learn/water\%20terminology/> (April 9, 2015)

Whelton, A. (2015). Conversation at the Lessons Learned Workshop, May 27. NCTC, Shepherdstown, WV.

Weidhaas, J., Buzby, K., Harris, A., Ziemkiewicz, P., Wang, K. and Lin, L. (2015). "MCHM/PPH in the Elk and Kanawha Rivers after the January 2014 Spill: Lessons Learned." Proc. Annual Meeting, West Virginia Task Force, Morgantown, WV.

Winter, T., Harvey, J., Franke, O. and Alley, W. (1998) "Ground Water and Surface Water: A Single Resource.” Circular 1139, USGS, Denver, CO.

Younger, P. (2001) "Mine water pollution in Scotland: nature, extent and preventative strategies." Sci. of the Total Environ., 265(1-3), 309-326. 
Ziemkiewicz, P. F., He, Y, and Quaranta, J.D. (2014a). "Characterization of Waste Waters from Hydraulic Fracturing." Proc. Shale Energy Engineering 2014: Technical Challenges, Environmental Issues, and Public Policy, American Society of Civil Engineers, Reston, VA, 63-73.

Ziemkiewicz, P. F., Quaranta, J.D. and McCawley, M. (2014b). "Practical measures for reducing the risk of environmental contamination in shale energy production." Environ. Sci.:

Processes Impacts, 16, 1692-1699. 


\section{Appendix A: Case Study Spills}

Table A 1 Spills related to oil and gas operations within the Remote Water Quality Monitoring Network (RWQMN) in the Susquehanna River Basin

\begin{tabular}{|c|c|c|c|c|c|c|}
\hline $\begin{array}{c}\text { API } \\
\text { PERMIT } \\
\end{array}$ & DATE & $\begin{array}{l}\text { FARM } \\
\text { NAME }\end{array}$ & COUNTY & TYPE & $\begin{array}{c}\text { VOL } \\
\text { (BBL) }\end{array}$ & SRBC Watershed \\
\hline $115-20263$ & $1 / 26 / 2011$ & R WARRINER 2 & Susquehanna & $\begin{array}{c}\text { Freshwater } \\
\text { Mud }\end{array}$ & 20 & EB Wyalusing \\
\hline $115-20404$ & $1 / 6 / 2012$ & COSNER 5 & Susquehanna & $\begin{array}{l}\text { Production } \\
\text { Fluid }\end{array}$ & 2 or 3 & Mesohoppen \\
\hline $115-20447$ & $2 / 13 / 2012$ & FRASER 1 & Susquehanna & $\begin{array}{l}\text { Production } \\
\text { Fluid }\end{array}$ & 20 & EB Wyalusing \\
\hline $115-21242$ & $8 / 2 / 2013$ & $\begin{array}{c}\text { CASTROGIOVA } \\
\text { NNI A } 4\end{array}$ & Susquehanna & Diesel Fuel & 3.5 & EB Wyalusing \\
\hline $115-20240$ & $8 / 27 / 2013$ & DEPAOLA 2 & Susquehanna & $\begin{array}{c}\text { Flow back } \\
\text { Fluid } \\
\end{array}$ & 1 & Mesohoppen \\
\hline $115-21406$ & $10 / 22 / 2013$ & STARZEC E 6 & Susquehanna & $\begin{array}{c}\text { Bentonite } \\
\text { drilling mud, } \\
\text { cement }\end{array}$ & 104 & EB Wyalusing \\
\hline $115-20487$ & $7 / 28 / 2011$ & BONNICE 1H & Susquehanna & $\begin{array}{c}\text { Mud and } \\
\text { water }\end{array}$ & 0.88 & EB Wyalusing \\
\hline $115-20228$ & $1 / 10 / 2011$ & TEEL UNIT $2 \mathrm{H}$ & Susquehanna & $\begin{array}{l}\text { Flow back } \\
\text { Fluid }\end{array}$ & 150 & Mesohoppen \\
\hline $115-21214$ & $8 / 7 / 2013$ & $\begin{array}{c}\text { OLIVER UNIT } \\
3 \mathrm{H}\end{array}$ & Susquehanna & Diesel Fuel & 2.3 & Mesohoppen \\
\hline $115-20461$ & $3 / 4 / 2011$ & DEPUE 8H & Susquehanna & Drilling Mud & 10 & Snake Creek \\
\hline $117-20197$ & $1 / 26 / 2011$ & ROOT 1 & Tioga & $\begin{array}{c}\text { Production } \\
\text { Fluid } \\
\end{array}$ & 50 & Hammond Creek \\
\hline $015-20352$ & $3 / 6 / 2012$ & BONNIE 2H & Bradford & $\begin{array}{l}\text { Corrosion } \\
\text { inhibitor }\end{array}$ & 0.47 & Sugar Run \\
\hline $015-20334$ & $11 / 8 / 2013$ & WELLES 3 2H & Bradford & Water & 0.59 & Sugar Run \\
\hline $015-20489$ & $6 / 24 / 2011$ & $\begin{array}{c}\text { CASTLE } 01047 \\
01 \mathrm{~J} 1 \mathrm{H}\end{array}$ & Bradford & $\begin{array}{l}\text { Production } \\
\text { Fluid }\end{array}$ & 20 & Sugar Creek \\
\hline $015-22058$ & $4 / 10 / 2012$ & $\begin{array}{c}\text { FEUSNER } 03 \\
044 \text { 05 J 5H }\end{array}$ & Bradford & Drilling Mud & 0.59 & Sugar Creek \\
\hline $081-21214$ & $1 / 30 / / 2014$ & $\begin{array}{c}\text { COP Tract } 357 \mathrm{~B} \\
1008 \mathrm{H}\end{array}$ & Lycoming & Brine & 20 & Little Pine Creek \\
\hline $081-20353$ & $7 / 3 / 2012$ & Arthur Unit $1 \mathrm{H}$ & Lycoming & $\begin{array}{l}\text { Flow back } \\
\text { Fluid }\end{array}$ & 130 & Little Muncy Creek \\
\hline $081-20255$ & $7 / 6 / 2012$ & $\begin{array}{c}\text { Kensinger Unit } 3 \\
\mathrm{H} \\
\end{array}$ & Lycoming & $\begin{array}{l}\text { Flow back } \\
\text { Fluid }\end{array}$ & 1 & Little Muncy Creek \\
\hline 081-20182 & $8 / 29 / 2011$ & $\begin{array}{c}\text { COP Tract } 293 \\
\text { Pad A } 2401\end{array}$ & Lycoming & Diesel Fuel & 6.5 & Little Pine Creek \\
\hline 081-20948 & $5 / 7 / 2013$ & $\begin{array}{c}\text { COP Tract } 293 \\
\text { Pad H } 2609 \\
\end{array}$ & Lycoming & $\begin{array}{l}\text { Production } \\
\text { Fluid }\end{array}$ & 0.7 & Little Pine Creek \\
\hline $081-21133$ & $5 / 12 / 2014$ & $\begin{array}{l}\text { COP Tract } 322 \\
\text { Pad B } 2663\end{array}$ & Lycoming & $\begin{array}{l}\text { Mixture of } \\
\text { mud, oil, } \\
\text { diesel fuel }\end{array}$ & 0.76 & Little Pine Creek \\
\hline $105-21665$ & $5 / 11 / 2011$ & $\begin{array}{c}\text { Coon Hollow } 904 \\
5 \mathrm{~h}\end{array}$ & Potter & $\begin{array}{l}\text { Production } \\
\text { Fluid }\end{array}$ & 12 & Pine Creek \\
\hline
\end{tabular}


Table A 2 RWQMN watershed profiles (SRBC 2012)

\begin{tabular}{|l|l|l|}
\hline RWQMN Watershed & $\begin{array}{l}\text { Drainage Area }\left[\mathbf{k m}^{2}\right] \\
\left(\mathbf{D}_{\mathbf{a}} \mathbf{}\right)\end{array}$ & $\begin{array}{l}\text { Average Annual Flow [cms] } \\
\left(\mathbf{Q}_{\mathbf{a}}\right)\end{array}$ \\
\hline Sugar Run & 85 & 1.4 \\
\hline Sugar Creek & 145 & 2.0 \\
\hline Little Pine Creek & 466 & 7.1 \\
\hline East Branch Wyalusing & 178 & 2.8 \\
\hline Little Muncy Creek & 132 & 2.3 \\
\hline Meshoppen & 135 & 2.1 \\
\hline Snake Creek & 116 & 2.1 \\
\hline Pine Creek & 997 & 15 \\
\hline Hammond Creek & 75 & 0.98 \\
\hline
\end{tabular}


Table A 3 Results of Emerson et al.'s (2005) Drainage Area Ratio Technique Comparing ungauged monitoring stations to gauged monitoring stations.

\begin{tabular}{|c|c|c|c|c|}
\hline $\begin{array}{l}\text { RWQMN } \\
\text { watershed name } \\
{\left[D_{\mathrm{a}, \mathrm{u}}\left(\mathbf{k m}^{2}\right),\right.} \\
\left.\mathbf{Q}_{\mathrm{u}}(\mathbf{c m s})\right]\end{array}$ & $\begin{array}{l}\text { 1) USGS monitoring } \\
\text { station name }\end{array}$ & $\begin{array}{l}\% \\
\text { Error }\end{array}$ & $\begin{array}{l}\text { 2) USGS monitoring station } \\
\text { name }\end{array}$ & $\begin{array}{l}\% \\
\text { Error }\end{array}$ \\
\hline $\begin{array}{l}\text { Hammond Creek } \\
{[75,1.0]}\end{array}$ & $\begin{array}{l}1533400 \\
\text { Susquehanna River at } \\
\text { Mesohoppen PA } \\
{[22,584 ; 365]}\end{array}$ & $-37 \%$ & $\begin{array}{l}1603500 \\
\text { Evitts Creek near Centerville, } \\
\text { PA }[77,0.9]\end{array}$ & $-15 \%$ \\
\hline $\begin{array}{l}\text { Sugar Run } \\
{[85,1.4]}\end{array}$ & $\begin{array}{l}1530332 \\
\text { Chemung River at } \\
\text { Elmira, NY } \\
{[5,594 ; 0.68]}\end{array}$ & $29 \%$ & $\begin{array}{l}1569000 \\
\text { Stony Creek near Dauphin PA } \\
{[85,1.8]}\end{array}$ & $-26 \%$ \\
\hline $\begin{array}{l}\text { Snake Creek } \\
{[116,2.1]}\end{array}$ & $\begin{array}{l}01503000 \text { Susquehanna } \\
\text { River at Conklin, NY } \\
{[5,775 ; 125]}\end{array}$ & $-16 \%$ & $\begin{array}{l}1452500 \\
\text { Monocacy Creek at Bethlehem } \\
\text { PA }[116,1.8]\end{array}$ & $-7.2 \%$ \\
\hline $\begin{array}{l}\text { Little Muncy } \\
\text { Creek } \\
{[132,2.3]}\end{array}$ & None available & N/A & $\begin{array}{l}1473120 \\
\text { Skippack Creek near } \\
\text { Collegeville, PA [139, 2.3] }\end{array}$ & $15 \%$ \\
\hline $\begin{array}{l}\text { Mesohoppen } \\
{[134,2.2]}\end{array}$ & $\begin{array}{l}1533400 \\
\text { Susquehanna River at } \\
\text { Mesohoppen, PA } \\
{[22,584 ; 365]} \\
\end{array}$ & $-8.6 \%$ & $\begin{array}{l}1473120 \\
\text { Skippack Creek near } \\
\text { Collegeville, PA [139, 2.3] }\end{array}$ & $4.5 \%$ \\
\hline $\begin{array}{l}\text { Sugar Creek } \\
{[145,2.0]}\end{array}$ & $\begin{array}{l}1531325 \\
\text { Sugar Creek at West } \\
\text { Burlington PA } \\
{[243,3.1]}\end{array}$ & $-2.8 \%$ & $\begin{array}{l}1451800 \\
\text { Jordan Creek near } \\
\text { Schnecksville, PA }[137,3.4]\end{array}$ & $-43 \%$ \\
\hline $\begin{array}{l}\text { EB Wyalusing } \\
{[178,2.9]}\end{array}$ & $\begin{array}{l}1533400 \\
\text { Susquehanna River at } \\
\text { Mesohoppen, PA } \\
{[22,584 ; 365]} \\
\end{array}$ & $-9.0 \%$ & $\begin{array}{l}1574500 \\
\text { Codorus Creek at Spring Grove, } \\
\text { PA }[197,2.8]\end{array}$ & $5.0 \%$ \\
\hline $\begin{array}{l}\text { Little Pine Creek } \\
{[466,7.1]}\end{array}$ & $\begin{array}{l}1549700 \\
\text { Pine Creek bl L Pine } \\
\text { Creek near Waterville, } \\
\text { PA }[2,434 ; 39]\end{array}$ & $-15 \%$ & $\begin{array}{l}\text { 01550000 Lycoming Creek } \\
\text { near Trout Run }[440,9.6]\end{array}$ & $-29 \%$ \\
\hline $\begin{array}{l}\text { Pine Creek } \\
{[997,15]}\end{array}$ & $\begin{array}{l}1548500 \\
\text { Pine Creek at Cedar } \\
\text { Run, PA }[1,554 ; 24]\end{array}$ & $-15 \%$ & $\begin{array}{l}03079000 \text { Casselman River } \\
\text { at Markleton, PA }[984 ; 20]\end{array}$ & $-23 \%$ \\
\hline
\end{tabular}

Note: 1) Of the same stream network; 2) of similar sized watersheds. $\mathrm{D}_{\mathrm{au}}$ is ungaged watershed drainage area; Dag is gaged watershed drainage area. 

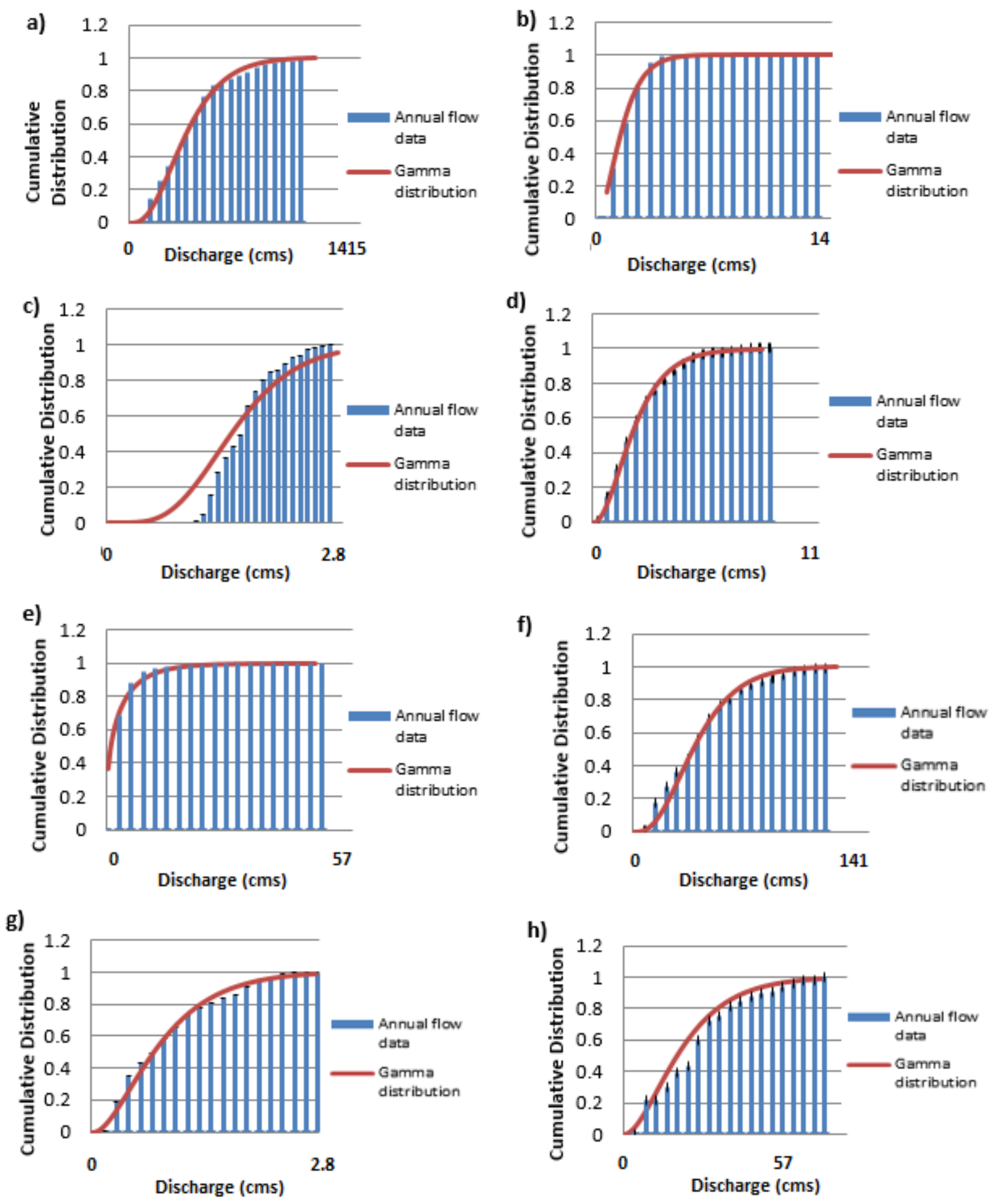

Figure A 1 Gamma distribution for the USGS monitored watersheds; a) USGS station 01533400 at the Susquehanna River, b) USGS station 01569000 at Stony Creek, c) USGS station 01452500 at Monocacy Creek, d) USGS station 01473120 at Skippack Creek, e) USGS station 01531325 at Sugar Creek, f) USGS station 01549700 at Pine Creek below Little Pine Creek, g) USGS station 01603500 at Evitts Creek, h) USGS station 01548500 at Pine Creek. 


\section{Appendix B: Laboratory Analysis Experimental Procedure}

1. The water quality sensors were suspended in a 1 gallon pail, and the pail was filled to submerge the sensors.

2. The apparatus is stirred with a magnetic stirrer.

3. The sensors are turned on and are allowed to stabilize for 5 minutes.

4. A chemical is diluted to a ppm as found by the model.

5. The chemical is added, at $1 \mathrm{ppm}$ increments, with 5 minute measurement time, at a recording frequency of fifteen seconds.

6. The water quality parameters are measured.

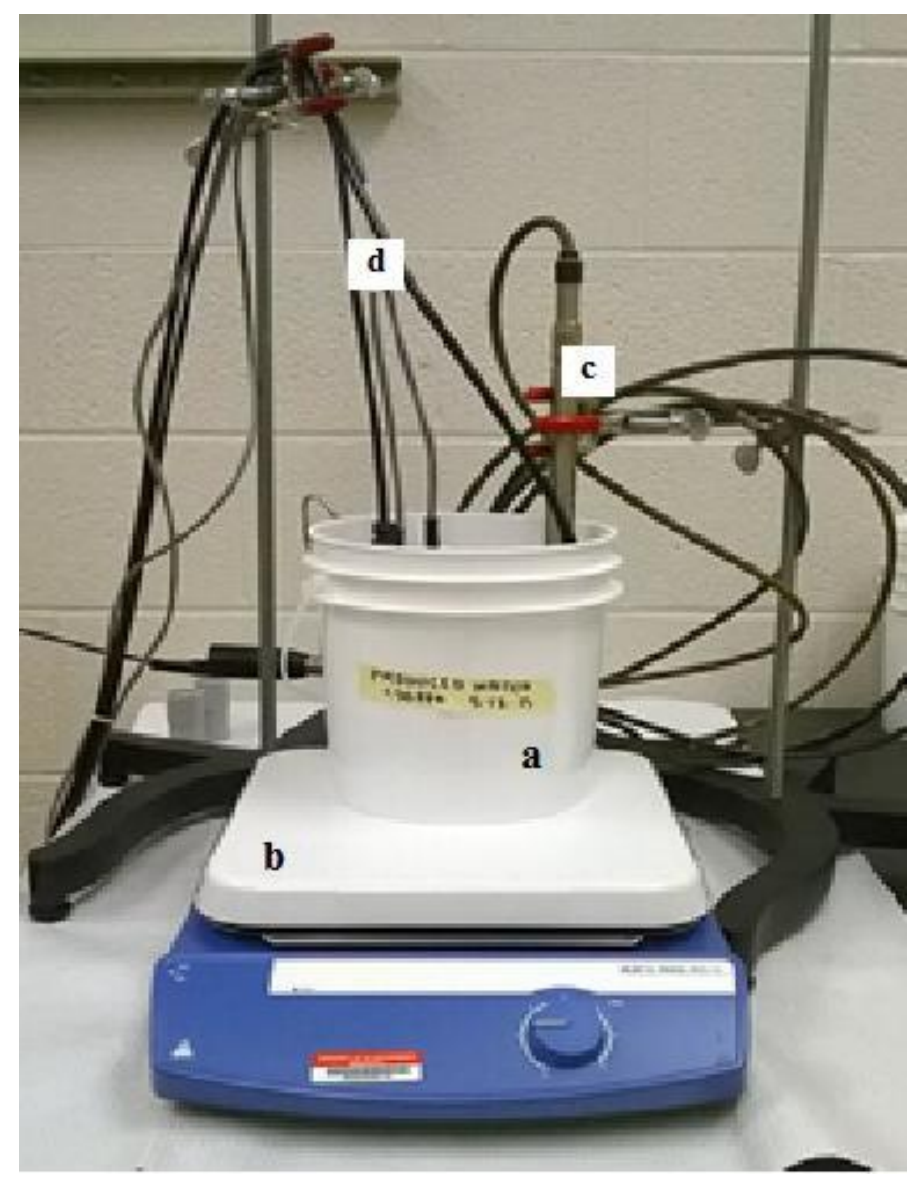

Figure B 1 Where a) is the pail containing deionized water; b) is the magnetic stirrer; c) is the AquaTROLL 200; d) are the CS-CR-1000 probes for $\mathrm{pH}$, dissolved oxygen, ORP and temperature/conductivity. 


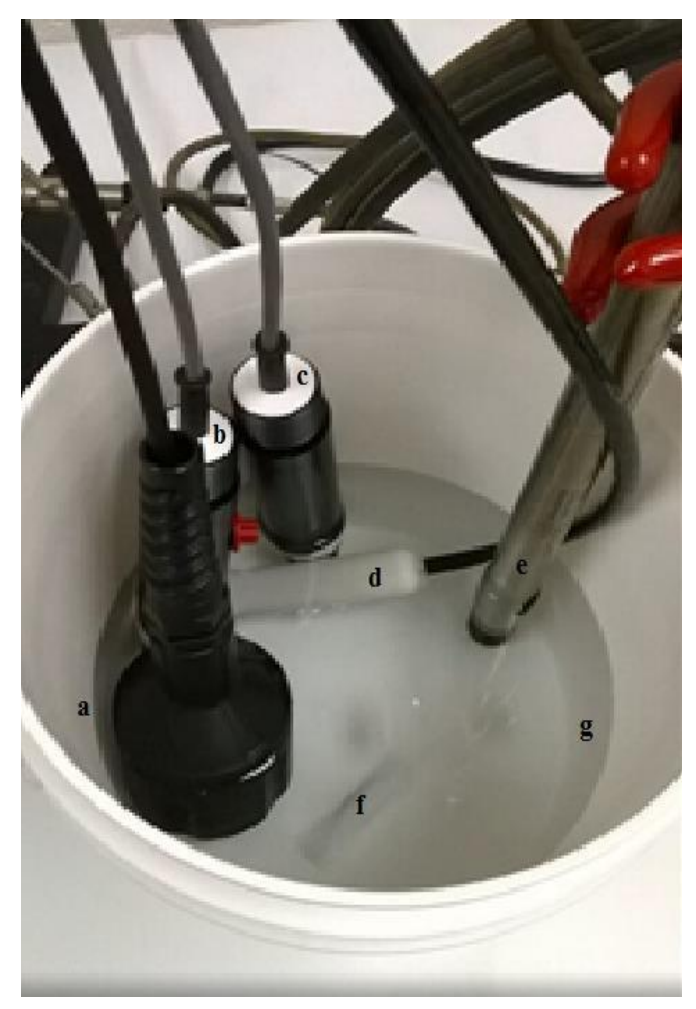

Figure B 2 Where a-d) are probes associated with the CS-CR-1000 system: a) is the dissolved oxygen probe, $b$ ) is the $\mathrm{pH}$ probe, $\mathrm{c}$ ) is the oxidation reduction potential probe, and $d$ ) is the temperature and conductivity probe. $E$ ) is the AquaTROLL 200, f) is the stir bar, and $\mathrm{g}$ ) is the deionized water in a one gallon pail. The probes are suspended by clamps on a test stand. 


\section{Appendix C: Elk River Spill}

Table C 1 Chemical properties of MCHM

\begin{tabular}{|c|c|c|c|c|}
\hline & Density & Solubility in water & Henry's Law Constant & $\begin{array}{l}\text { Molecular } \\
\text { weight }\end{array}$ \\
\hline MCHM & $\begin{array}{l}0.9074 \mathrm{~g} / \mathrm{cm}^{3} \\
\text { at } 20^{\circ} \mathrm{C} \\
(\text { Lide } 1994)\end{array}$ & $\begin{array}{l}2.024 X 10+3 \mathrm{mg} / \mathrm{L} \text { at } \\
25^{\circ} \mathrm{C} \\
\text { (US EPA 2012b) }\end{array}$ & $\begin{array}{l}5.8 X 10-2 \mathrm{~mm} \mathrm{Hg} \text { at } 25^{\circ} \mathrm{C} \\
6.43 \mathrm{X} 10-6 \mathrm{~atm}-\mathrm{m}^{3} / \mathrm{mol} \text { at } 25^{\circ} \mathrm{C} \\
\text { (US EPA 2012b) }\end{array}$ & $128.21 \mathrm{~g} / \mathrm{mol}$ \\
\hline
\end{tabular}

